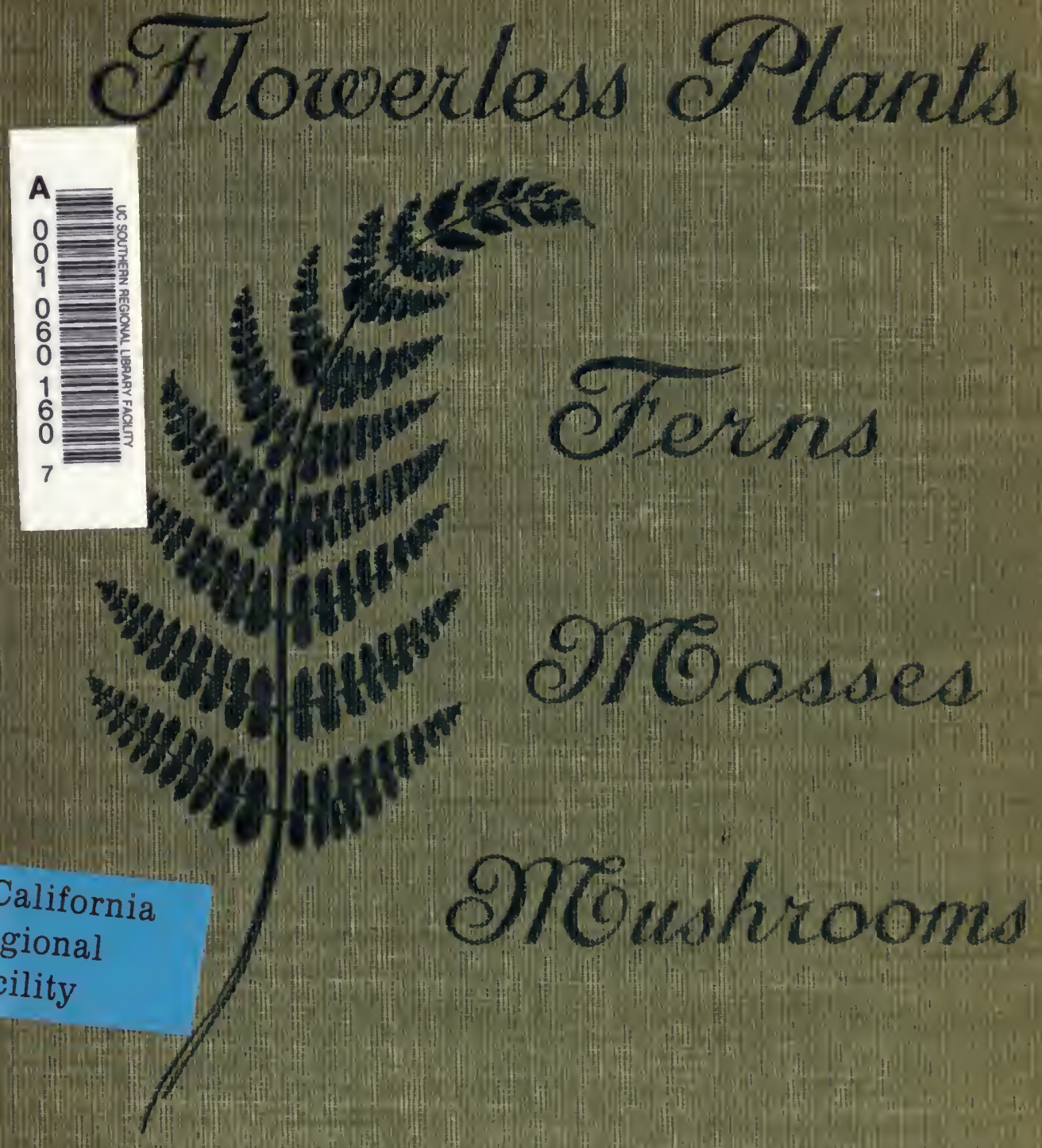


Clice Trimble

smogor frominother. 
Flowerless Plants 


\section{Digitized by the Internet Archive in 2007 with funding from Microsoft Corporation}




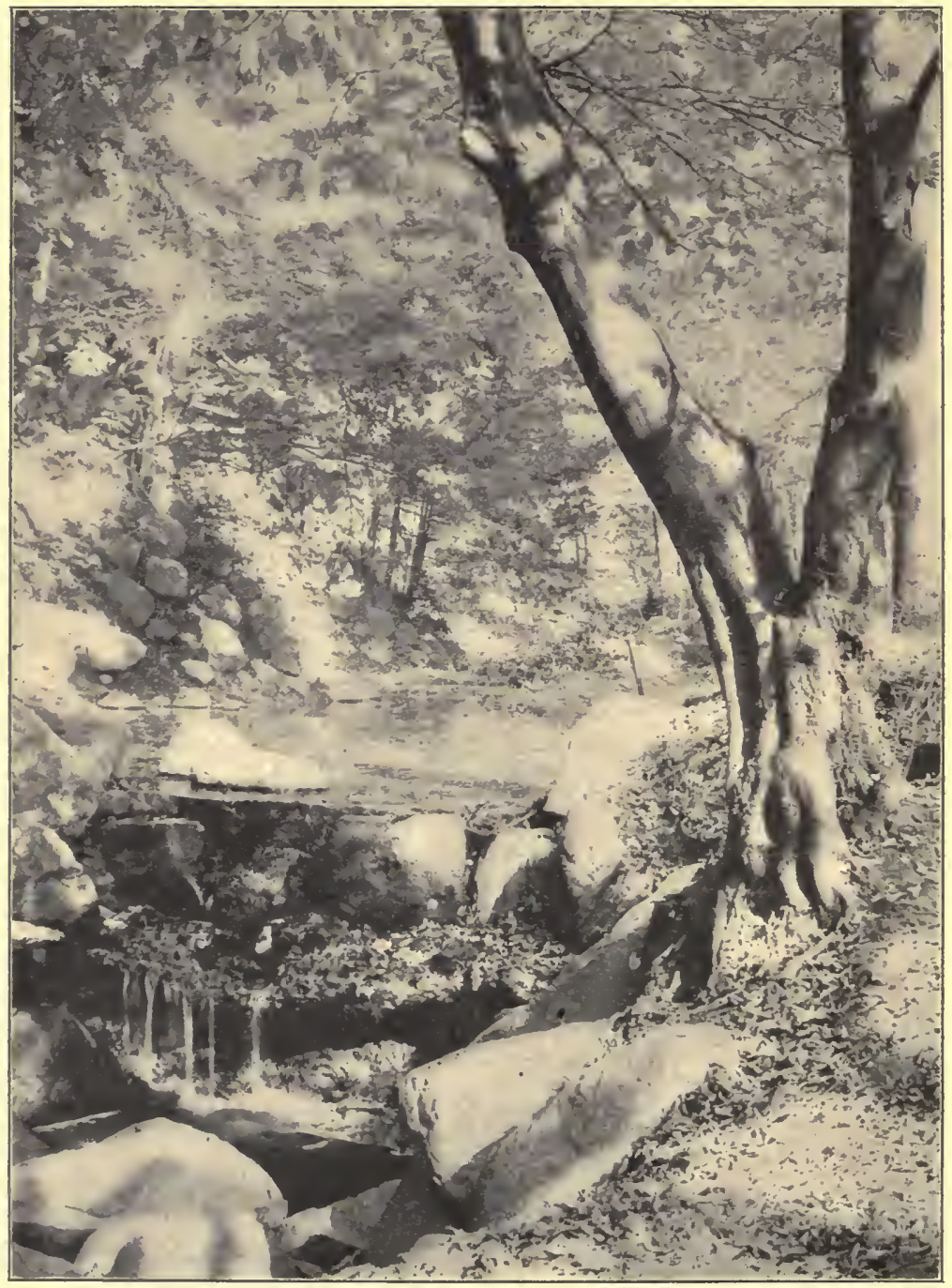

Go Forth Under the Open Sky and List to Nature's Teachings. 


\title{
Flowerless Plants
}

Ferns, Mushrooms, Mosses, Lichens, and Seaweeds

\author{
By \\ ELIZABE'IH H. HALE, A.B. \\ Head of Department, \\ Public Schools, Brooklyn, New York
}

Nature ever yields reward

To him who seeks, and loves her best.

- Corswall.

\author{
NEW YORK \\ GEORGE S. HULBERT \& COMPANY \\ 1907
}


Copyright, 1907, by George S. Hulbert \& Company

The Trow Press, New York 


\section{exte \\ an \\ $0 c: 4597727$}

\section{PREFACE}

THE purpose of this book is threefold:

1. To interest children in flowerless plants and to lead them to a desire for further knowledge.

2. To present a few facts in such a way as to enable the reader to discover for himself others equally interesting.

3. To aid many who have found it difficult to obtain information on this subject without a tedious search through volumes not easily procured.

It is earnestly to be hoped that this book will in no sense displace the study of the real plants, but that it may be rather an incentive and an aid to field work. More can be learned out "under the open sky" than from any book, and there is greater pleasure in knowledge thus gained. This book is but an introduction to nature's flowerless plants, for this is all that can be presented in so small a volume.

An effort has been made to secure illustrations that will be helpful, and to keep the language within the comprehension of the young readers, whom we wish to reach. For this reason few technical terms have been used, and these in such a way as to be readily understood.

For several years the author has studied nature in 
the woods and fields, and at home with the microscope. Among the books consulted which have been especially helpful for ferns are Gray's Manual, Mrs. Dana's How to Know the Ferns, Clute's Our Ferns in Their Haunts, and Waters's Ferns. To the last we are especially indebted for information about spores and the growing of young ferns.

Marshall's Mushroom Book, Gibson's Our Edible Toadstools and Mushrooms, Palmer's About Mushrooms, and Atkinson's Studies of American Fungi have been most helpful in the work on those interesting plants.

For the study of mosses and lichens Macmillan's Footnotes from the Pages of Nature, Grout's books on Mosses, and Lindsay's British Lichens were consulted. Hervey's Sea Mosses and Arnold's Sea Beach at Ebb Tide were of great assistance in the study of seaweeds.

Nearly all the illustrations were from the author's own specimens. To Mr. Henry E. Bedford we are indebted for the photographs, and to Miss Sylvia C. Warren for her assistance in the color work and in the pen and ink sketches.

To Miss Emma L. Wagenseil we are under obligations for some of our specimens of mosses.

Our thanks are also due to Mr. Edward B. Shallow, Associate Superintendent of Schools in Greater New York, for reading the manuscript, for helpful suggestions, and kindly words of encouragement. 


\section{CONTENTS}

Nature's Teachings . . . . . . . . . 9

Parts of a Feri . . . . . . . . . . 13

How Ferns Grow . . . . . . . . . 15

Other Ways to Start New Ferns . . . . . 19

FERNS IN SPRING . . . . . . . . . . 22

Through the YeAr with the Ferds . . . . . 25

The Marsh FerN . . . . . . . . . 28

The Bracken . . . . . . . . . . 30

The Rattlesnake Ferx . . . . . . . . . 33

The Ebony Spleenwort . . . . . . . . . 36

The Maidenhair Fern . . . . . . . . . 38

The Osmundes . . . . . . . . . . . . 40

ThE LADY FERN . . . . . . . . . . . 44

The Sensitive FerN . . . . . . . . . 46

The Christalas Fery . . . . . . . . . 48

The Spinulose Wood Ferx . . . . . . . 50

The Common Polypod . . . . . . . . . 52

The Rusty Woodsia . . . . . . . . . 54

The Evergreen Wood Fern . . . . . . . 57

Ferns in Stone And CoAl . . . . . . . 58

Mushroovs . . . . . . . . . . . 62

Parts of a Mushroom . . . . . . . . . 6 J

How Mushrooms Grow . . . . . . . . 68

The Common Meadow Mushroom . . . . . 70

The Fairy-Ring Mushroom . . . . . . 73 


\section{CONTENTS}

The Boleti . . . . . . . . . . . 76

PINK CAPS . . . . . . . . . . 77

The Amanita Famly . . . . . . . . 79

Tree Mushrooms . . . . . . . . . . 82

Puffballs . . . . . . . . . . . . 86

The Coral Fungi . . . . . . . . . 88

Mosses . . . . . . . . . . . . . . . 91

Parts of the Moss Plant . . . . . . . 94

Tree Mosses . . . . . . . . . . . . . 98

PeAt Moss . . . . . . . . . . . . . . 99

Fern Mosses . . . . . . . . . . . . 102

HaIr-Cap Mosses . . . . . . . . . 103

Hypnum Mosses . . . . . . . . . . 105

Water Mosses . . . . . . . . . . . . 109

Other Common Mosses . . . . . . . . . 113

LicheNs . . . . . . . . . . . 119

Reindeer Moss . . . . . . . . . . . 123

ICELAND Moss . . . . . . . . . . 124

Lichens AS Dyestuffs . . . . . . . . 126

A Few Common Lichens . . . . . . . 128

Seaweeds . . . . . . . . . . . . . 132

Ulva . . . . . . . . . . . . 135

FuCUs, or RockWEed . . . . . . . . . 136

Sargassum, or Gulfweed . . . . . . . . . 138

Edible Seateeds . . . . . . . . . . . 141

Giant Seaweeds . . . . . . . . . 144

Sea TANgle . . . . . . . . . . . 145

Sea Flowers . . . . . . . . . . . 148 


\section{NATURE'S TEACHINGS}

LONGFELLow tells us to go to the woods and hills and learn lessons from nature. And Bryant, too, another of our poets, says

$$
\begin{aligned}
& \text { "Go forth under the open sky and list } \\
& \text { To Nature's teachings." }
\end{aligned}
$$

If you would do this, you might learn what a wonderful teacher nature is. Perhaps the birds would tell you how they build their nests and take care of their little ones. In the woods and fields you would find

$$
\begin{aligned}
& \text { "On many a green branch swinging, } \\
& \text { Little birdlets singing." }
\end{aligned}
$$

Soon you would learn to know each by its song, even when you could not see it.

Then there are those busy little creatures, the insects and spiders! They would show you how many things they have to do and how they do them. Among them is

"The honeybee that wanders all day long The field, the woodland, and the garden o'er, To gather in his fragrant winter store." 


\section{NATURE'S TEACHINGS}

Here, too, is the ant, whose example all idle people are told to follow. You may learn from the insects that the smallest of God's creatures have work to do.

The soil and the rocks can tell you wonderful stories. They have traveled great distances and have seen many strange sights along the way. When you know them well, you can often find out where they have come from.

You have already learned many things about plants; you can name their parts and you have seen the beautiful blossoms fade and die. You know that from them comes the seed with its baby plant wrapped close to protect it from harm.

But do you know that there are some plants upon which no bright, fragrant blossoms are ever seen? It is about these flowerless plants that we are going to read in this book. Perhaps you think that there are not many of them. If so, you are mistaken; there is really a greater number of flowerless plants than there is of flowering ones. Among them are ferns, mosses, and seaweeds. Others are the lichens, ground pine, and fungi, such as toadstools, or mushrooms.

The ferns are the largest of them all. They are also the most like the flowering plants. Like them their leaves are closely .packed away from the winter's cold. When spring comes, the ferns stretch up ipto 


\section{NATURE'S TEACHINGS}

the light and send up green leaves borne upon slender stems. It is because the ferns are so much like flowering plants that we are going to read about them first.

As we go on with our story you will learn many things about these plants. But reading is not seeing, and Mother Nature's invitation is, "Come and see."

You can learn more from the plants themselves "under the open sky" than you can from books.

Then go into the woods and fields when you can. But do not wait to do that. Use your eyes wherever you are. In the country the ferns are growing along the roadside. Mosses, lichens, and toadstools, or mushrooms, are almost at your feet as you walk about. Even in the city streets we may see these. You may find moss upon the walks, on the cellar wall, and in the neighboring patches of short grass. Do not pass these by if you would like to know what they can teach you.

Do you remember the story of Fawn-footed Nannie and what she saw and heard? Suppose that you try to make your ears and eyes like hers.

"'Fawn-footed Nannie, where have you been?'

'Chasing the sunbeams into the glen,

Plunging thro' silver lakes after the moon,

Tracking o'er meadows the footsteps of June.' 


\section{NATURE'S TEACHINGS}

'Fawn-footed Nannie, what did you see?'

'Saw the fays sewing leaves on a tree; Saw the waves counting the eyes of the stars, Saw cloudlamps sleeping by sunset's red bars.'

'Nannie, dear Nannie, take me with you, too, So I may listen and see as you do.'

'Nay! you must borrow my ear and my eye, Or music will vanish and beauty will die."" 


\section{FERNS}

\section{PARTS OF A FERN}

LET us first try to find out something about the parts of a fern. Do you remember how many kinds of roots you found when you studied flowering plants? The roots of ferns resemble some of these. They are like stems growing under the ground and sending out little rootlets, as you see in the picture. This under-

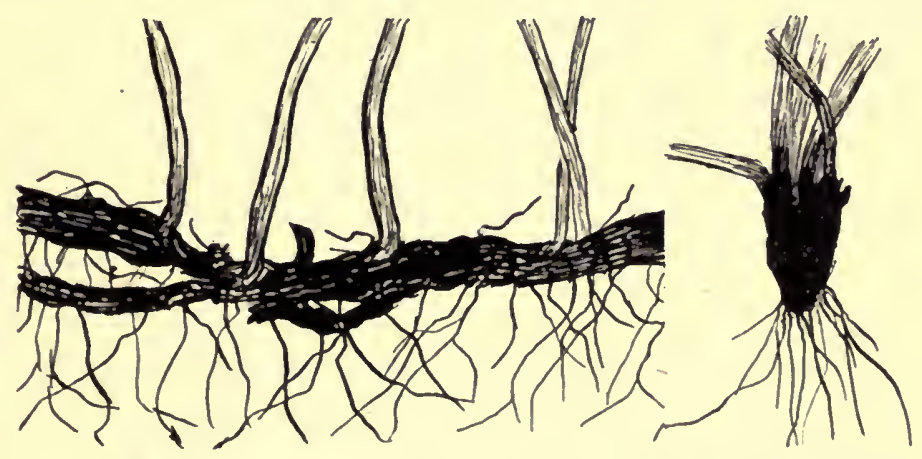

A Slender, Creeping Rootstock.

A Short, Stout Rootstock.

ground stem is called a rootstock. Some rootstocks are short and stout. . They send up their leaves in circles, but only in the spring. In these circles the 13 
younger leaves are always in the middle. In the very center you will find circles of buds which afterward grow into leaves.

Other kinds of ferns have long, slender rootstocl-which creep along under the ground and have many

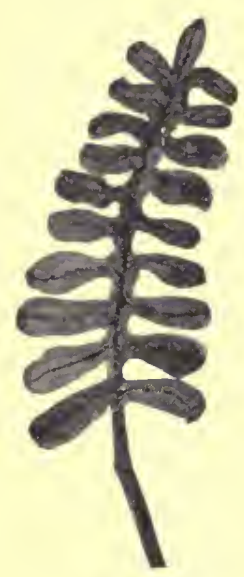

A Fern Frond.

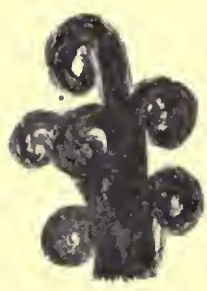

Fern Buds Uncoiling. branches. The leaves of these come up in irregular clusters, or else single leaf grows up here and there along the rootstock. New ones come up every little while during the summer.

The buds of ferns are different from those of flowering plants. They are always coiled or folded close. Very rarely do we find this arrangement in any other plant. When

a bud is all uncoiled, the leafy part is known as the blade. The stem, or stalk, of the fern leaf is called a stipe. The blade and stipe together form the frond, but the blade alone often receives this name.

The work of a plant is to grow. The parts needed for this work are a root, a stem, and leaves. The fern has all of these.

Nature has given each part something to do. She 14 


\section{HOW FERNS GROW}

says to the root: "Cling fast to the earth and hold this plant in its place. Get all the food and drink that you can from the soil and give them to the nerm."

To the stipe she says: "Take the food and water from the rootstock and carry them to the leaves, for they need these to help them grow large and strong." Then she asks the leaves to take the nourishment that is brought them and to spread out their blades, so that the light and moisture may reach every part, for she wants them to grow just as fast as they can.

And the busy little ferns will help to make us happy by doing their part to make our earth more beautiful.

\section{HOW FERNS GROW}

WE have learned that the work of all plants is to grow. Flowering plants have other work to do. When they have grown large and strong enough, they put forth flowers. Later still, they are very busy forming seeds and caring for them. By and by new plants will grow from these seeds.

Flowerless plants do not have flowers or seeds, but Mother Nature finds another way for them to give us new plants.

If, in midsummer, you look on the under side of 


\section{FERNS}

the fronds of some of our common ferns you will see many small, brownish. spots. These are fruit dots.

Sometimes each fruit dot has a thin, whitish cover-
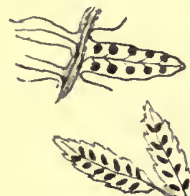

sisi
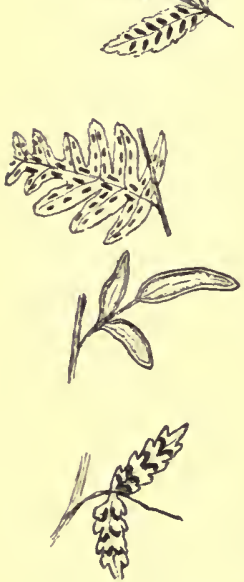

Parts of Fern

Leaves with

Fruit Dots. ing. This hides it until it is nearly ripe. The fruit dots are made up of small bodies called spore cases. Within these are the spores, which are set free when ripe. These spores take the
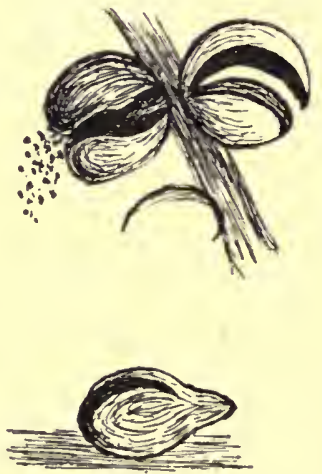

SIDE VIEW
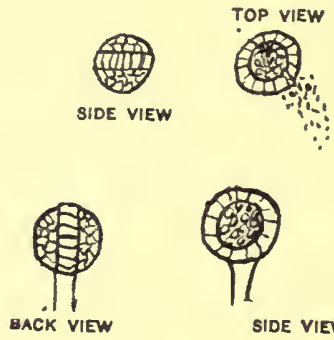

SIDE VIEW

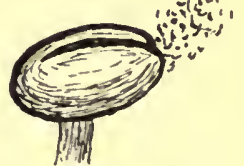

SIDE VIEW

Forms of Spore Cases.

place of the seeds which we find in flowering plants. From them come new plants.

Here are pictures of the spore cases of some of our common ferns. See how the spores are scattered. Notice the stalked spore case. Around it is a jointed 


\section{HOW FERNS GROW}

ring. When the spores within are nearly ripe the ring becomes dry. This causes a strain that bursts the spore case. The ring straightens out with a jerk, tearing open the spore case and scattering the spores in all directions. The wind often
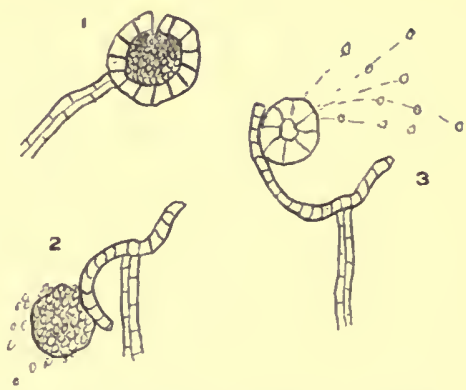

The Stalked Spore Case. 1, Closed; 2 , Open; 3 , Scattering the Seeds.

a

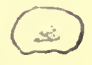

b
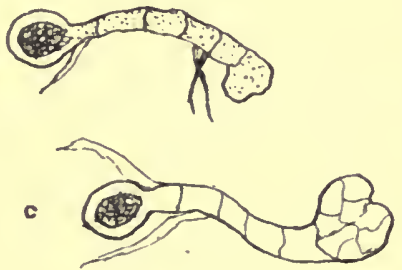

d

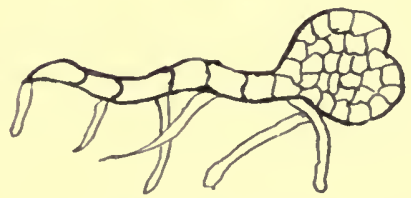

a, A Spore before it Begins to Grow; $b$, Opened Spore with Tube Showing Cross Partitions and Root-like Hairs; $c$, Tube with End Flattened into Prothallium; $d$, Tube with Prothallium Full Grown. carries them great distances.

When the spores are set free they fall to the ground. If the soil is moist, they will begin to grow in a few days. The brown coat bursts open. A long tube, divided into cells by cross partitions, springs from it. Then hairlike roots are seen here and there. These fasten the young plant to the soil. Soon the end of the tube flattens out and forms 


\section{FERNS}

a small, green, platelike object. This is called the prothal'li-um. When fully grown it is less than half an inch across. On the under side of this are two sets of organs. One set does the work of the stamens of the flower. The other set does the work of the pistils. By the union of the contents of these two sets of organs a new fern plant is formed.

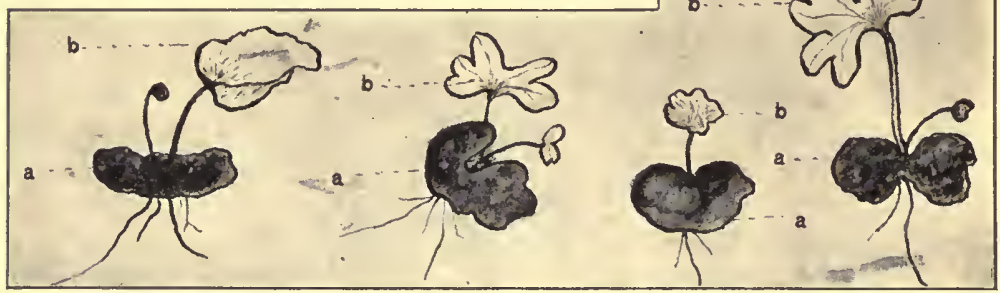

Young Fern Plants. a, Prothallia from which Young Plants Grow; $b$, Leaves of the Young Fern Plants.

The first leaves of the little plant are very small and simple, not at all like the later ones. They are so nearly alike in most of our ferns that you cannot tell one from another when the plants are very small. The young fern receives its food through the prothallium until it is old enough to take care of itself. Then the prothallium dies away.

Do not mistake spores for seeds. Both fall from the parent plant when fully ripe. Both begin to grow if they fall upon a moist soil. But a seed, when planted, sends up a plant like the parent; a fern plant does not 


\section{OTHER WAYS TO START NEW FERNS}

come up from a spore. The prothallium comes first, and from that the fern grows.

If you have sharp eyes you may be able to find fern prothallia in the woods or fields. Look for them along the moist and shaded banks of a stream or on decaying stumps. You may also see them at the florists', where they are found in the boxes used for growing young ferns. Sometimes they are on the outside of flowerpots, where the spores have fallen accidentally and have begun to grow.

Perhaps you would like to raise some ferns from spores. It is very easy and you would enjoy watching them. Put some rich earth in a deep flowerpot saucer. Scatter some spores over the surface of this earth, and keep the soil moist by placing the saucer in a plate containing a little water. Cover the saucer with a deep glass dish. This screens it from the sun and keeps the earth moist. Look for the spores to begin to grow in about a week. Sometimes it takes longer than that; so do not become discouraged if they do not appear on time. From three to seven years is required for a fern to become old enough to have spores of its own.

\section{OTHER WAYS TO START NEW FERNS}

You have learned how ferns begin to produce spores, and also how the young plants grow from these spores. But the ferns have other ways to start new plants. 


\section{FERNS}

Some of the rootstocks send out branches in all directions. After a while these branches send up their own fronds. Then they separate from the old rootstock and form new fern plants.

One dainty little fern has all along the under side of the stem curious little bulbs about the size of a grain of pepper. After a while these fall to the ground.

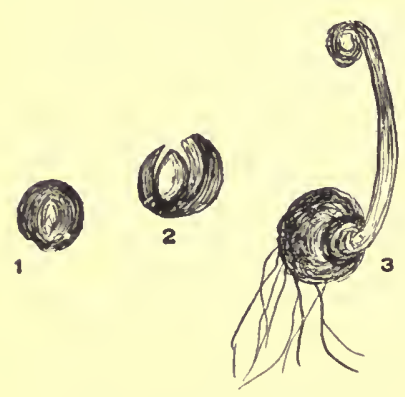

Fern Growing from a Bulb.

In a week or two new plants begin to grow out of them. Each bulb is made up of two or three little bits of fleshy green scales joined together at the base. If you watch them at this time, you will see a couple of slender roots springing from between the scales. These reach down into the soil. Then a tiny frond begins to uncoil from the heart of the bulb. After it come larger and larger ones, until it is a good-sized plant. As these fronds grow, the rootstocks push out from the bulb, growing larger and thicker as the fern gains strength.

There is a fein, called the walking fern, which has another way of forming new plants. In August the fronds are fully grown. Then the tips of some of the longer ones bend down against the rock or into the moss. Soon a young plant with two or three tiny fronds is found growing upon the end of the leaf. 
Let us see how these young plants start. At first the end of the frond becomes thicker. Soon a tiny frond begins to uncoil. Others follow, until a little rosette of from three to six leaves is pressed close against the moss. The young plant keeps its connection with the

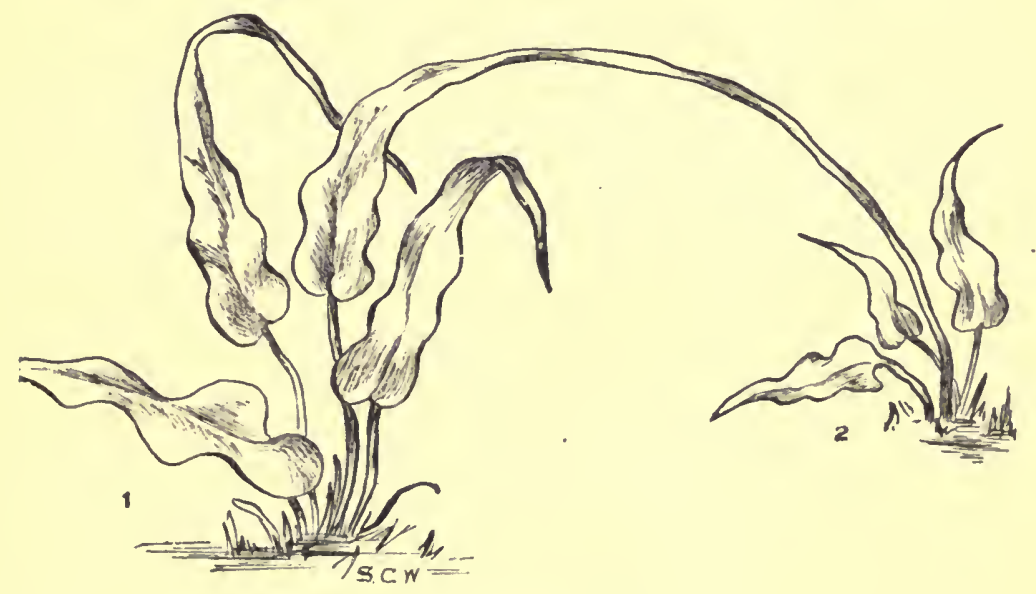

The Walking Fern.

older one until the next summer. Then the large frond withers away and the young fern starts out upon an independent life. In this way these ferns spread rapidly. Notice in the picture the lobes at the base of the leaves. Sometimes new plants are formed on these in the same way. There are a few other ferns that start young plants in this manner. 


\section{FERNS}

\section{FERNS IN SPRING}

The soft air and the warm sunshine seemed to say: "Good news! Good news! Winter is going away! Come out into the woods and fields." What do you think we found? The robin and the bluebird had come. Pussy Willow had taken the scales from her winter buds, and they were all soft and furry. On some of the shrubs and trees the leaf buds were starting out. The early spring plants were beginning to put forth their delicate blossoms.

What is that down among the rocks and fallen trees? A few weeks ago there was a mass of dead leaves, mixed with brown papery or hairlike scales. Now, something green is beginning to grow. The parts are all coiled up like little watch springs! There is only one kind of a plant that comes up in that way. It must be a fern and those are its uncoiling buds. They are called crosiers.

The crosiers are not alike in all ferns. Some are clothed with a coat of silvery-white wool. These are sometimes called fiddleheads. When the weather becomes warmer, they will turn to a yellowish brown and the woolly covering will disappear. Over there by the roadside is another kind of crosiers. They are covered with soft, short hairs of a silvery gray. Instead of the one coil, there are three divisions, which unroll separately. 


\section{FERNS IN SPRING}

In the woods, we see circular clumps of uncoiling buds. They are thickly covered with silky white scales that make them easily seen above the dark soil. Along the stream there are some slender crosiers somewhat

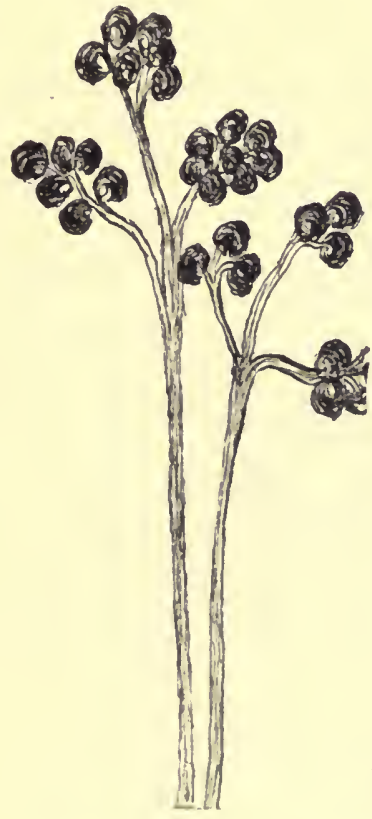

Crosiers with Three Divisions.

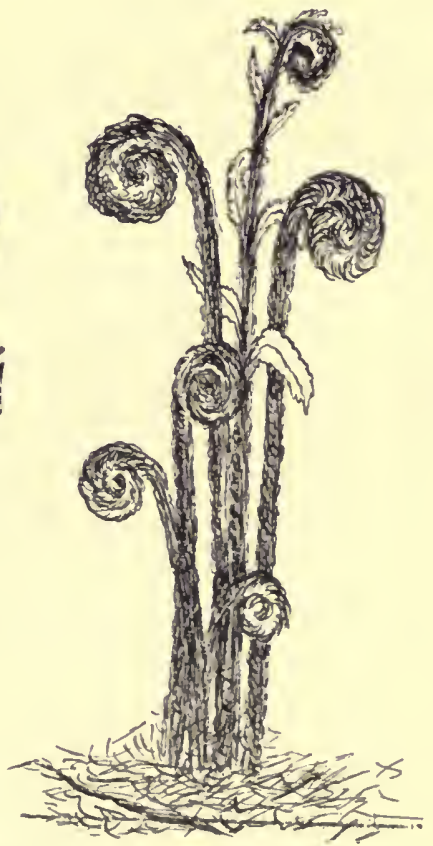

"Fiddleheads."

different in shape. They look like little green spheres as they nod at the tops of their long stems.

Here are three kinds that show brighter colors in their uncoiling fronds. The first has a stipe of a clear 23 


\section{FERNS}

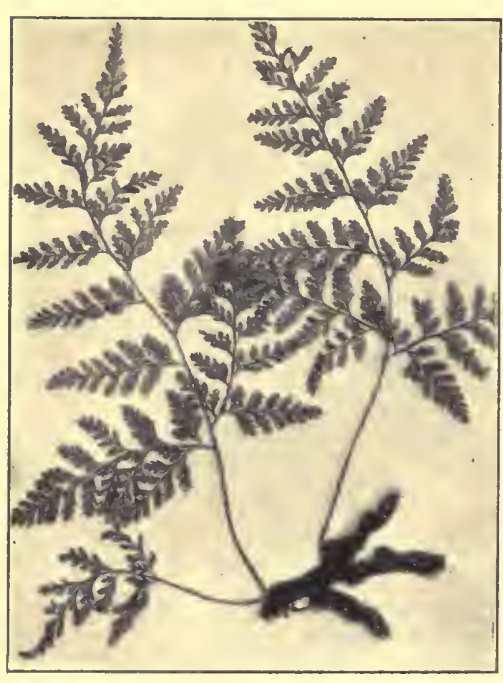

"The Green and Graceful Fern, How Beautiful it is."

wine color with light, thin scales. The leafy part is of a yellowish green. Another mass of buds has a tawny pink hue. A third kind belongs to a fern having a delicate frond. The crosiers are slender and the stems are covered with a bluish bloom. The uncoiling leaves are of a dull-red color. These ferns give a touch of brightness to the spring woods.

One of our poets has written the following lines about the fern at this season:

"Have ye e'er watched it budding,

With each stem and leaf wrapped small,

Coiled up within each other

Like a round and hairy ball?

Have ye watched that ball unfolding,

Each closely nestling curl,

Its fair and feathery leaflets

Their spreading forms unfurl? 


\section{THROUGH THE YEAR WITH THE FERNS}

Oh, then most gracefully they wave

In the forest, like a sea,

And dear as they are beautiful

Are these fern leaves to me."

\section{THROUGH THE YEAR WITH THE FERNS}

Once uncurled, the ferns spread out their broad leaves and grow and grow. By the first of June their waving fronds may be seen in all directions. Many of then are water-lovers. These grow beside the running brook or in the midst of a tangled swamp. We may also find them on the rocks close to the waterfall.

"Far upward 'neath a shelving cliff,

Where cool and deep the shadows fall,

The trembling fern its graceful fronds

Displays along the mossy wall.

The wild flowers shun these craggy heights-

Their haunts are in the vale below;

But beauty ever clothes the rocks

Where Nature bids the ferns to grow."

During the months of July and August most of the ferns are full of leaves. On the under side of some of the fronds we see the brown velvety spores. Other plants have tall branching fruit clusters. These are 


\section{FERNS}

the months to find some of our rarest ferns. But this is not always easy. If you really wish to see

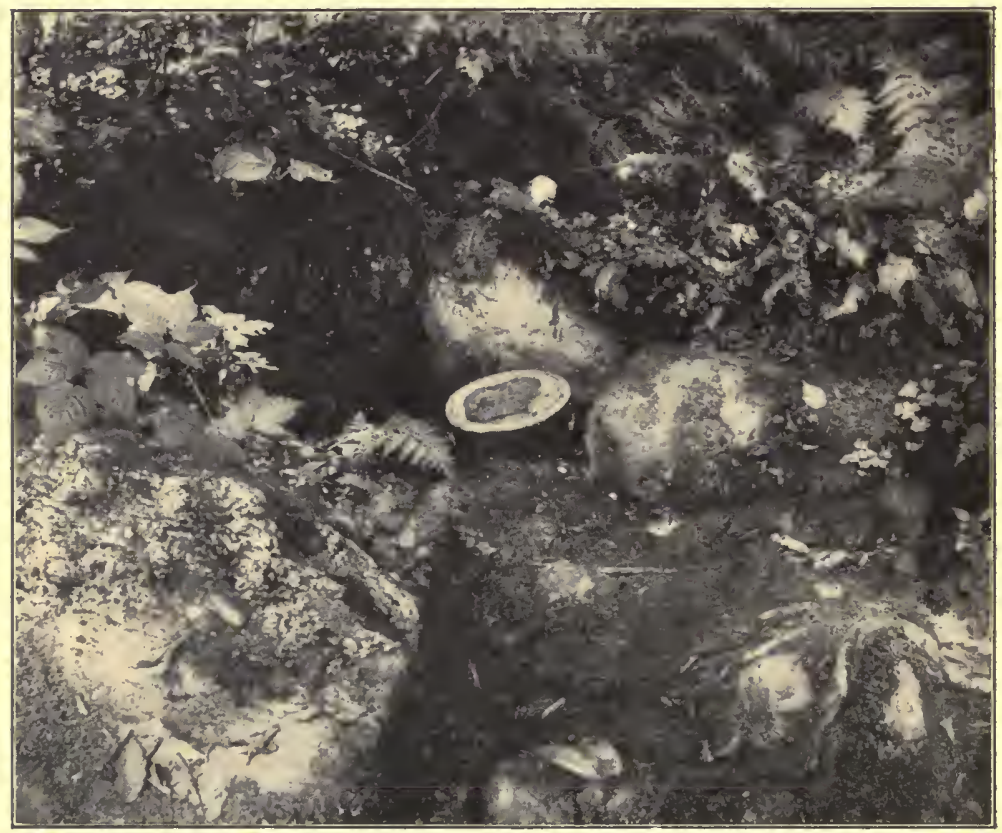

Where Some of Our Ferns Grow.

No other plants know so well how to choose their haunts. If you wish to know the ferns you must follow them to Nature's most sacred retreats. - Mrs. Dana.

them you must search for them in nature's hiding places.

When you get there, you will find other things, too: the bright-colored butterflies, the rocks with their car- 


\section{THROUGH THE YEAR WITH THE FERNS}

pets of mosses and lichens, and the wild fruits and flowers.

In September some of the late ferns show ripened spores. Then come the bright days of October, when the trees and shrubs are clothed in orange, red, bronze, and yellow. Many of the ferns, too, change color. A few are bleached almost white. Some wear gowns of a yellowish tint, while others dress in brown. Near by is a neighbor in orange.

All of these gradually disappear until we are left with the evergreen ferns in their sober dresses. Their stems become weakened by the cold and seem unable to hold the plants erect.

Our coldest winter months come. But even then we find some ferns that are proof against the ice and snow. They nestle close to the earth and are not harmed by the sharp, cold winds that blow about them. Here we may find them if we visit the woods in winter. No trace of green is seen among the others. They look as if they were dead. But listen to what they have to say:

"You think I am dead,

The dainty fern said,

Because I am coiled so small!

I never have died,

But safe I hide

In a soft and fuzzy ball. 


\section{FERNS}

Here I can rest through the long winter time;

When the robins call,

I shall hear them all,

And up I'll begin to climb."

This voice comes from yonder mass of dead leaves. Now we remember that it was from such a place as this that the crosiers grew up in the spring. So we know that these fern children sleep in warm beds. Instead of soft wool blankets like ours, a close covering of. brown leaves is provided. Under these they are snug and warm during the cold winter.

\section{THE MARSH FERN}

Do not think that because this plant is called the marsh fern it always grows in swanıs. While that is its favorite dwelling place, it is also found in wet woods and by roadside ditches, where

$$
\begin{aligned}
& \text { "O'er the turbid water's breast } \\
& \text { The plumes are waving green." }
\end{aligned}
$$

It is occasionally seen in dry pastures. The fronds that are shown in the picture were found in a cattle pasture through which ran a small brook. The cattle, by their trampling, had made a soft, watery mud along the banks of this stream. Here the ferns had found a spot that suited them. 


\section{THE MARSH FERN}

You see that they have rather stiff-looking fronds. These are of a pale, dull green. The stipes are usually very long for the size of the frond.

Early in the spring, before other marsh plants come up, the slender crosiers of this fern appear. They look like little green balls nodding to each other, from the tops of their tall stipes. The rootstocks are long and slender. The leaves come up during the "whole summer. None of the early fronds bear spores.

About the middle of July the spore-bearing, or fertile, fronds appear. The fruit dots are in a double row on each leaflet. They are

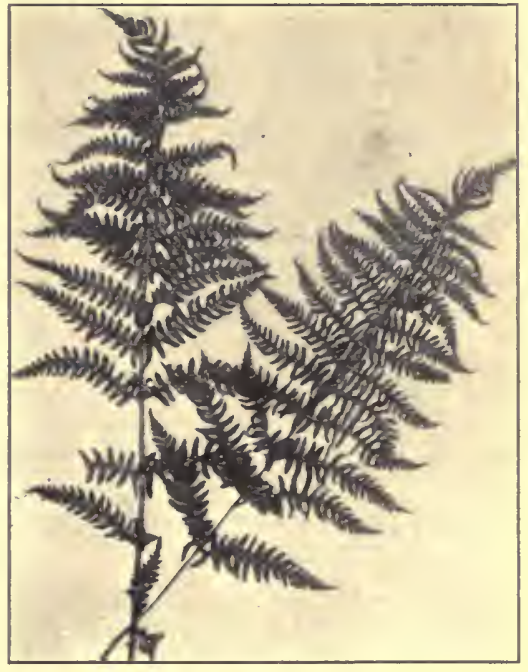

The Marsh Fern. well grown before the frond uncurls. The edges of the leaves are turned over to the under side, so as to cover the fruit dots when they are young. Perhaps you can see this in the frond at the left, which has its under side toward you.

As the spores ripen, the spore cases spread out and often cover all the under side of the leaf. One writer 


\section{FERNS}

says that these leaflets with their edges turned over are thought to look very much like tiny, half-open snuff-boxes. For this reason the plant has been called the snuff-box fern. The fruited fronds are heavier than the early sterile ones. The spores ripen in September.

In deep woods the marsh fern grows tall and slender, but has little fruit. In the sun it has much fruit, but the fronds become thick and yellowish and are often twisted. Sometimes the ends of the fronds turn half-way around, while the tips of the leaflets bend toward each other.

After the first sharp frost the fronds that are in exposed places generally wither. In sheltered situations they may keep green for a month or more longer. Never shall we find them defying frost and showing their green plumes amid the ice and snow of winter.

\section{THE BRACKEN}

ONE of the commonest of American ferns is the bracken. It often grows to be several feet in height. Its smooth, black rootstock is deep in the earth and has many branches. The crosiers are covered with silvery-gray down. They come up singly at intervals of from six inches to six feet. The three divisions, unrolling separately, look somewhat like the claws of a large bird. 


\section{THE BRACKEN}

The picture shows you a branch of a full-grown frond. It is coarse and spreading. The color is a dark, dull green. All fronds are about the same shape. The edges of the spore-bearing ones are bent over to form a covering for the spore cases. When young this covering makes a silvery-white edging on the under side of the frond. As the spores ripen, they push it back and peep out. Then they turn to a deep, rich brown and make the frond look as if it were embroidered.

Other names for this plant are brake, umbrella fern, upland, and eagle fern. The last name was probably given because of something eaglelike about the plant. Perhaps it was the clawlike crosiers,

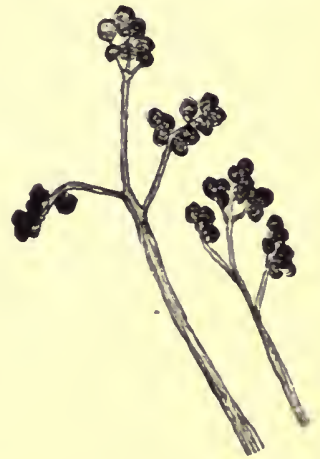

Crosiers of the Bracken. or it may have been that the broad fronds looked like an eagle's wings.

There are many superstitions about the bracken. At one time it was thought to protect one from goblins and witches. In the seventeenth century it was the custom to burn the bracken when rain was needed.

The bracken is the fern that was supposed to bear the "mystic fern seed." According to the legend, fern seed could be obtained from this plant on mid- 


\section{FERNS}

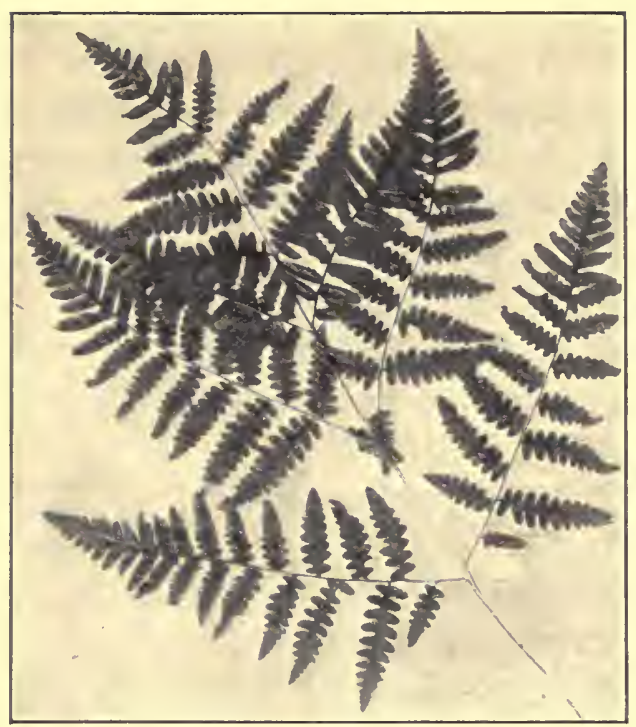

The Bracken. summer eve only. At dusk the fern was supposed to put forth a tiny blue flower. This soon gave place to a small, shining seed that ripened at midnight. If it fell from the stem of its own accord and was caught in a white napkin, it was thought to give its possessor the power to become invisible.

"It boasteth a name of mystic fame,

For who findeth its magic seed

A witching and weirdly gift may claim,

To help him in his need;

Unseen, unknown, he may pass alone

Who knoweth the fern seed's spell;

Like the viewless blast, he sweepeth past,

And walks invisible."

The bracken is one of the useful ferns. Fruit, fish, and vegetables are sometimes packed in it to keep 
them from mildew and decay. The young crosiers may be cooked and eaten like asparagus. These are often sold in the Japanese market. In some places in Europe the roots have been ground and mixed with flour in making bread.

Houses have been thatched with the large bracken fronds. In some parts of the world they are used as a bedding for cattle. The fresh plants are sometimes of service in tanning light leathers, as they contain much tannic and other acids. In Scotland they used to be burned when green. Then the ashes were made into balls to be used instead of soap.

The bracken is very hard to transplant and start in a new place; but when once started it is just as difficult to root it out.

\section{THE RATTLESNAKE FERN}

OxE of the ferns that grows in the woods is the rattlesnake fern. It does not like the sunshine. It seems to delight in dim, moist hollows, but soon disappears from a place when the trees are removed.

Early in May you will find the hairy leaf buds just unfolding. Let us see how this fern grows.

A tangle of thick, fleshy roots extends horizontally a few inches under ground. From this comes a single frond. If you look at the picture, you will see that 


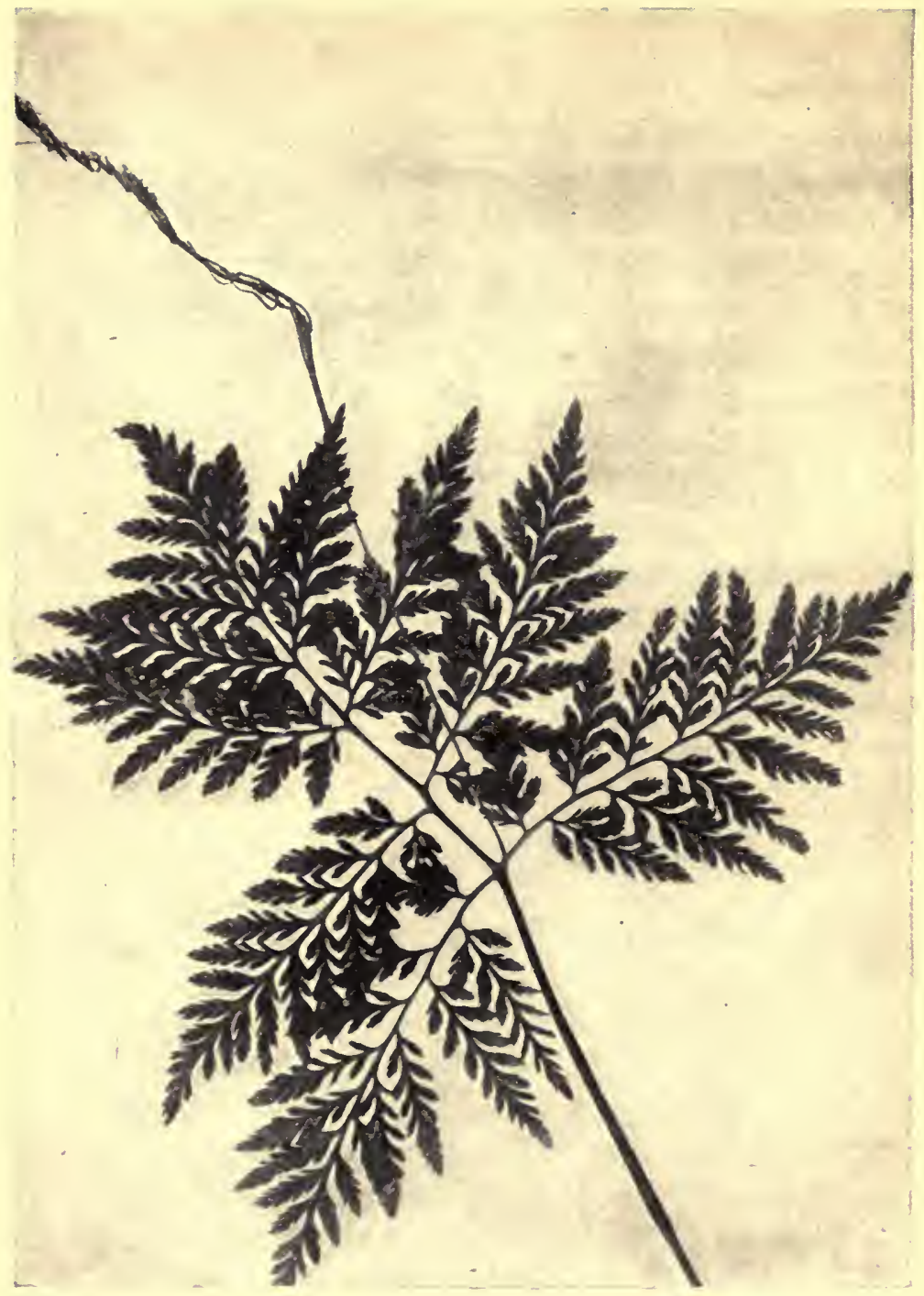

The Rattlesnake Fern. 
this is divided into two parts, one of which bears the spores. The green blade spreads out in a broad, flat triangle. It is much cut and divided and quite thin. If you can get some of these fronds and press them you will find that they have a very delicate appearance, and show beautiful shades of color.

The spore-bearing part of the frond rises several inches above the green blade. As the spores ripen the spaces between the parts lengthen. There is finally a long, slender cluster with the parts (called branchlets) nearly parallel to the stalk.

The bright-yellow spores ripen in June. They escape from the spore cases through a narrow slit across it.

In a hollow at the base of the stipe is a bud for next year's leaf. Within its tiny stem may be found a still smaller bud, and this in turn incloses another. So we may say that this plant has its clothing prepared three years ahead. The spore cases also begin to grow a year or more before the spores are shed.

There is a great difference in the size of these fern plants. Some that are not more than three or four 35 


\section{FERNS}

inches high bear fruit clusters. There are others that are five or six times as large.

The name of rattlesnake fern was probably given to this plant because of a likeness which was thought to exist between the spikes of fruit and the rattle of the snake. It is sometimes called the grape fern, because its clusters of spore cases look like bunches of grapes.

\section{THE EBONY SPLEENWORT}

ThE fern whose picture you see on the opposite page belongs to a large family called "spleenwort." A great many members of this family live in the United States. We shall read about one only, the ebony spleenwort. The home of this fern may be the woods, the fields, or the roadside; but in a stony soil, for it is a true rock lover.

Notice in the picture how it grows. The rootstock is small and the leaves grow in tufts. See how different the fronds are. The short ones that spread out close to the ground have no spores. Their leaflets are close together. The fronds that bear the spores are much longer and their leaflets are farther apart. They generally spring up from the center and stand erect. This helps them to scatter their spores to a greater distance.

You can see spores on two of the fronds. They al36 


\section{THE EBONY SPLEENWORT}

ways grow in double rows on each leaflet, some distance from the edge. When young they have a white covering, which soon withers away. Then the spore cases spread out and cover most of the under side of the frond.

The ebony spleenwort takes its name from its dark, shining stem. It is sometimes called the screw fern. This is because the sporebearing leaflets grow upon the stem in such a way that they look like the threads on a screw. You cannot see this very well in the picture. It may be easily noticed in a

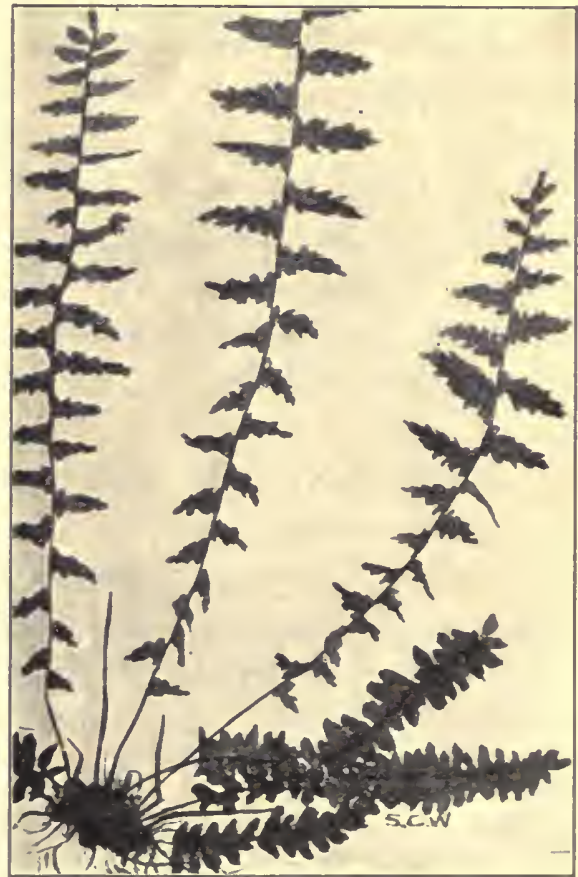

The Ebony Spleenwort. growing plant.

This fern is found in the United States as far westward as Colorado. The plant from which the picture was made came from the fields of Long Island. 


\section{FERNS}

\section{THE MAIDENHAIR FERN}

A FERN that is often seen at the florist's is the maidenhair. But you will not find such large plants in the greenhouse as are found "under the open sky." Even out of doors there is a great difference in the size of the plants. The larger ones grow in moist, shaded dells. They love "a quiet glen shut in from all intrusion by the trees." On dry slopes the plants are smaller. In the sunlight they are quite small.

If you have once seen a maidenhair fern you will be apt to know it again. It is not shaped like any of the other ferns that we have been reading about. Neither does it grow like them. The outline of the whole frond is circular. The stem is very slender and is hidden as you look down upon the plant. This makes the fern look as if it were top-heavy. But if a ground breeze comes along while you are looking at it, you almost forget that you thought so. The mass of green is all atremble. The shining, dark stipe is no longer hidden, but glistens as the soft green top waves to and fro.

The rootstock is near the surface of the ground. It is slender and creeps about for a long distance, giving off many black, wiry roots. Before the leaves push up out of the ground, they are protected by 


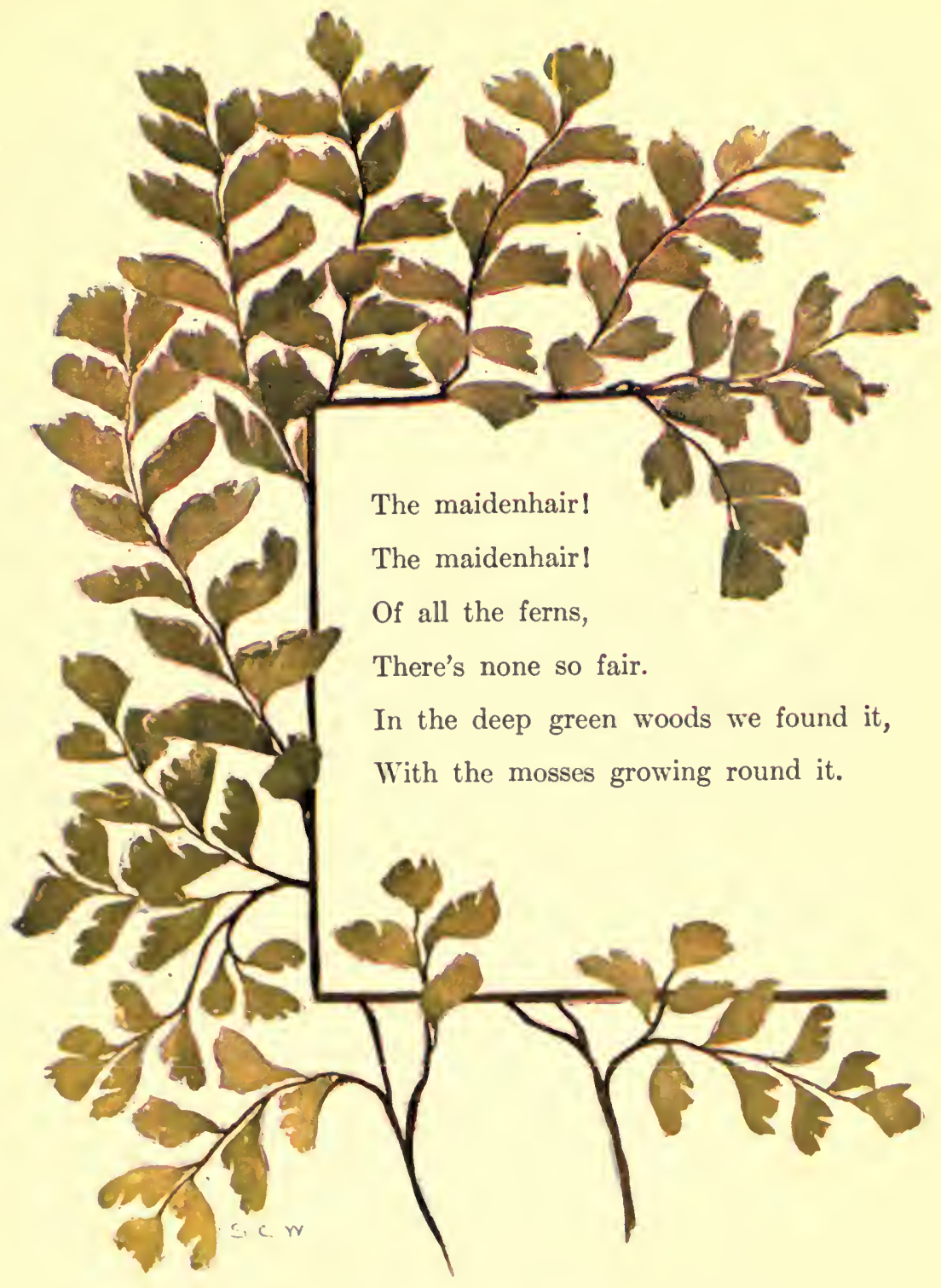

Maidenhair Fern. 
•

1 


\section{THE MAIDENHAIR FERN}

brown, hairlike scales. When the young crosiers begin to uncoil they wear all shades of pale green and red. The stems vary from red and purplish to brown. Nearly every frond has spores. You can see the fruit dots along the outer margin of some of the fronds.

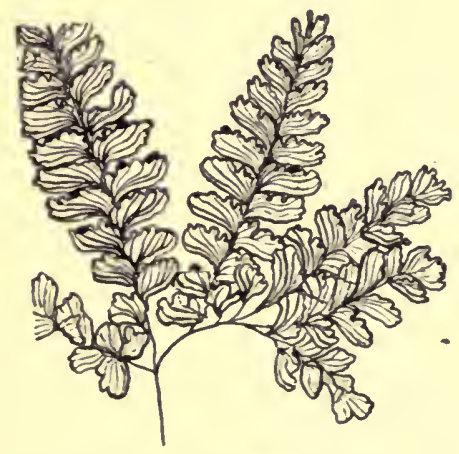

Frond of the Maidenhair Young Maidenhair Show- Venus's Hair. Fern.
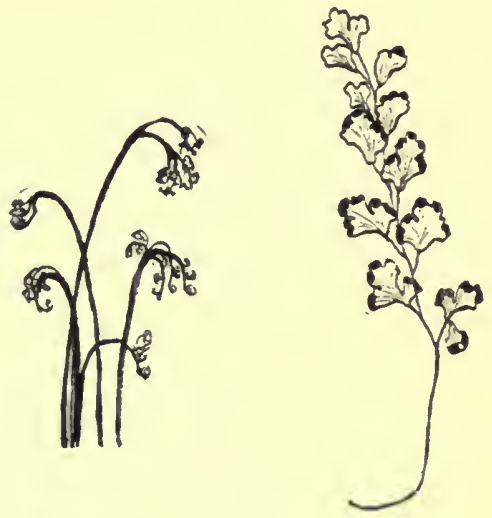

ing Bends in Stem.

In the picture they are covered by the rolled-over edges of the leaflets.

On account of the smoothness of the fronds, rain and dew roll off this plant without wetting it. For this reason men who study about plants have given this fern the name of Ad-i-an'tum, which means "without wet." The name of maidenhair is said by some to have been given on account of the slender black stems. Others think that this name was used be- 


\section{FERNंS}

cause the fine, black, wiry roots resemble the hair of a maiden.

This fern is sometimes used for medicine. It is said to be good for throat and lung diseases.

There is a fern in Europe and in the southern part of our own country that looks somewhat like the maidenhair. It is called the Venus's hair fern. If you look at the little sprays of these two plants you will see the difference in the shape of the leaflets. The Venus's hair branches alternately along the stem instead of forming a circle of branches at the top of the stipe as the maidenhair does.

\section{THE OSMUNDAS}

The Os-mun'-das are ferns that everybody ought to know, because they are so common and so showy. From the time their crosiers peep out of the ground in the spring until their leaflets fall in the autumn, they are a familiar sight. Their roots are the largest, their crosiers the wooliest, their fronds the tallest, and their fruit the earliest of any of the ferns.

The three best known members of the Osmunda family are the cinnamon fern, the interrupted fern, and the flowering fern.

Early in the spring, before the grass has turned green, the young crosiers or "fiddleheads" of the cin- 


\section{THE OSMUNDAS}

namon fern begin to appear in wet ground. The spore-bearing fronds are seen first, but before they are full grown the other fronds spring up and grow so fast that they are soon taller than the earlier ones. These two sets of fronds grow in separate circles. The fruit-bearing ones form the outer circle, but during their growth the others bend outward, so that when full grown those with spores appear to be growing in the inner circle.

The fruiting fronds are stiff and clublike, as seen in the picture. At first they are bright

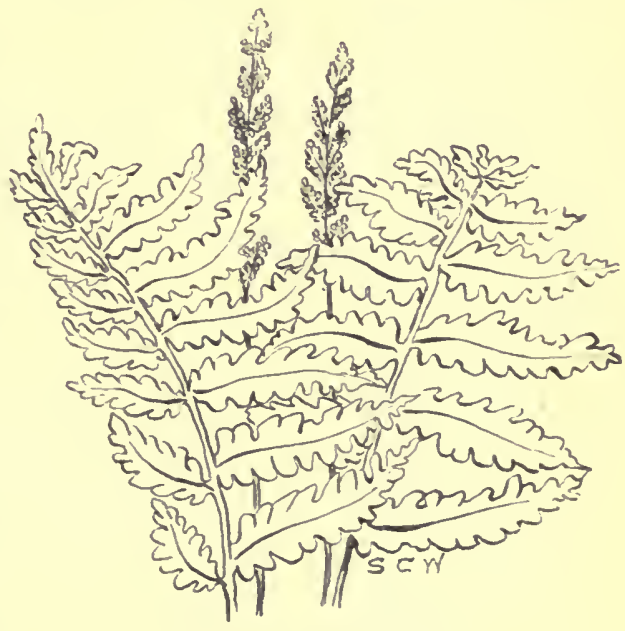

The Cinnamon Fern.

green. In the latter part of May they begin to turn to the cinnamon brown which gives this fern its name. The spores are now ripe and a touch sets them free. The fronds then wither and die. The other leaves remain green during the summer.

The thrush and the brown thrasher like to build their nests in the center of these great ferns.

Though an early riser in the spring, the cinnamon 


\section{FERNS}

fern cannot get ahead of the interrupted fern. This is the first of the Osmundas to appear. It starts as soon as Mother Nature calls and never waits to take

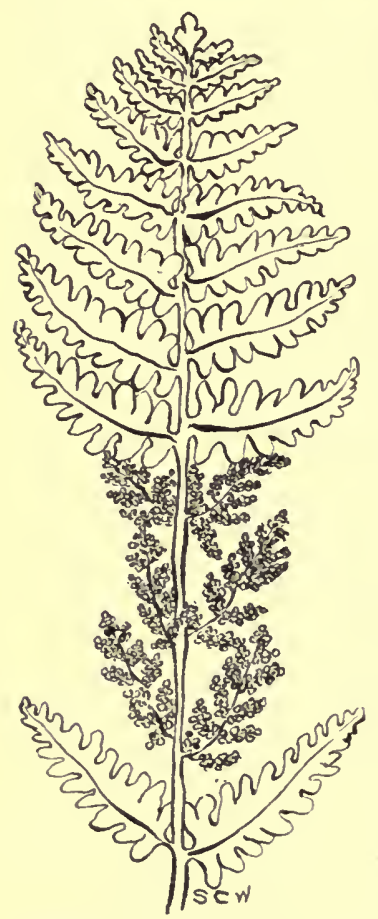

The Interrupted Fern. another nap. At first it looks so much like the cinnamon fern that it is not easy to tell them apart.

The interrupted fern does not care so much for moisture, but it likes the roadside and pasture. Both kinds of fronds begin to grow at about the same time. The stipes are slenderer than those of the cinnamon fern. They are also less downy. When the buds uncoil, the small fronds are wholly green, but in the taller ones this color is interrupted by a few pairs of leaflets that bear spores. At first the spores are dark green, almost black, and look very pretty in the midst of the yellow-green of the rest of the frond. Later they turn brown. It is the way in which the spores grow that gives this plant the name of interrupted fern.

The third member of the Osmunda family, the 
flowering fern, loves the water. The uncoiling fronds have dark-red stipes and reddish-green or pinkish blades. As these uncurl, the bright green spore cases may be seen peeping through the leaflets, which clasp them closely.

Notice in the picture how different the leaves are from those of other ferns. They grow very tall, often reaching a height of six feet. All the fronds are alike except that spores are borne on the upper part of some of them. This fruiting part at the end of the frond looks somewhat like a bunch of small flowers. Like the other Osmundas, the spores are a bright green until they ripen.

In all the Osmundas

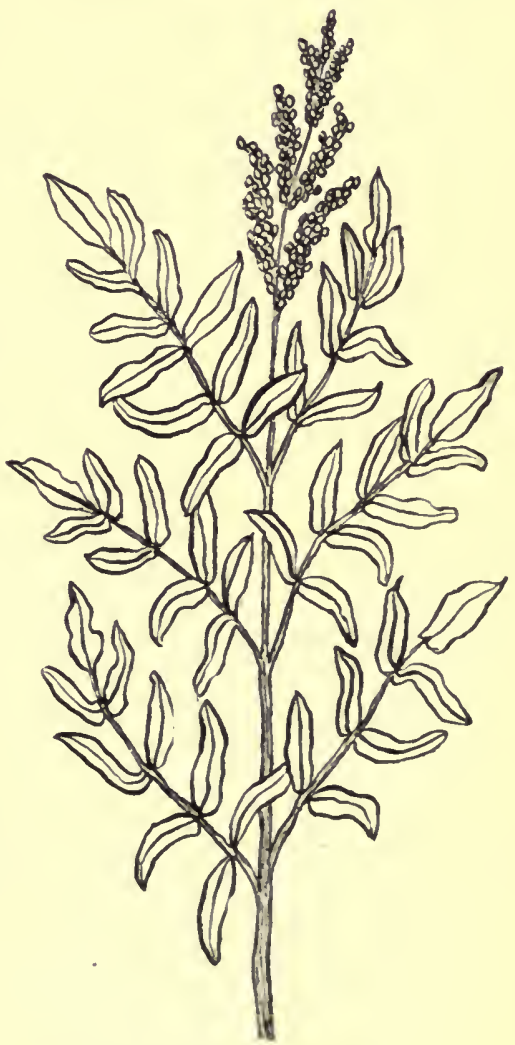

The Flowering Fern. the buds for several years to come are found nestling in the midst of the circle of fronds. This central part is called the heart 


\section{FERNS}

of Osmund. It is crisp and tender and is good to eat. It tastes somewhat like raw cabbage.

While all members of the Osmunda family are so common in America, only one, the flowering fern, is found in Europe. It is one of the handsomest of British ferns. One of the English authors speaks of this plant as the "flower-crowned prince of British ferns."

\section{THE LADY FERN}

The picture shows you a fern found in all parts of our country. Sometimes it is seen growing among a tangle of wild things in

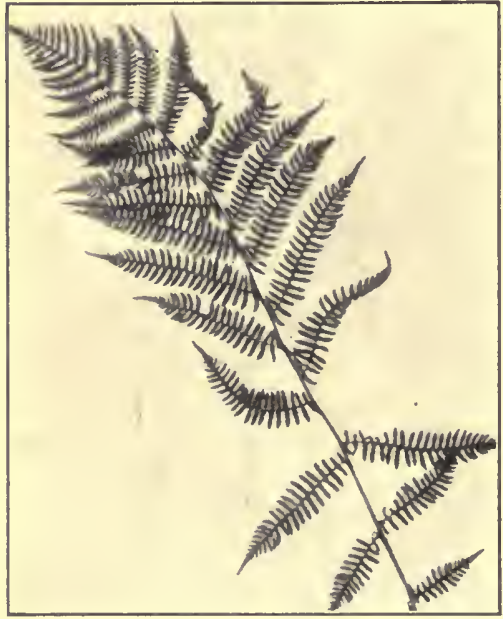

The Lady Fern. the pasture, sometimes by the roadside, and again in the low moist woodland.

The fronds spling up in circles from a large rootstock, often reaching a height of three feet or more. Notice how delicate and lacelike they look.

If you visit the haunts of the lady fern in May, you will find the earliest 


\section{THE LADY FERN}

fronds just awaking from their winter's sleep. The stipes have a reddish color and light, thin scales. These contrast prettily with the yellow green of the uncoiling blades.

Go again in June where

"The Lady Fern flourishes graceful and tall,"

and you find beautiful fronds of delicate green. In late summer you see these fronds in tints of brown and gold. Some of them have become blotched and broken, but others are still beautiful.

"But not by burn in wood or vale

Grows anything so fair

As the Lady Fern when the sumbeams turn

To gold her delicate hair."

The spores of the lady fern are good ones to plant because they grow so easily. Pick fronds that are heavy with fruit dots. Dry them in a paper bag for a day or two, until the spores are set free. Then plant them as you learned in an earlier chapter. The prothallia and young plants of different sizes are easily found on moist earth where this fern grows.

An English author calls it the Queen of Ferns, but we have many that retain their beauty longer than this one. 


\section{FERNS}

\section{THE SENSITIVE FERN}

August is a good time to wander through the fields in search of ferns. Along the banks of the streams one may find large, coarse-looking plants that grow in dense clumps. These are sensitive ferns. Go nearer and examine them carefully. Hidden away at the bottom of the mass of fronds are some tiny coiled crosiers for next year's leaves. Here and there are stems that look exactly like the lower part of the stipe, but they end in a point. They have no leaves and are never more than two or three inches long.

The rootstock is about as large as a pencil and creeps along under the ground, sending out many branches. The fronds come up from these at different times during the summer. See how broad these coarse leaves are. They are triangular in shape, and the edges are very deeply cut.

Does it not seem strange that the name "sensitive" should be given to a plant with such large, coarse fronds? It was probably called by that name because the early frosts so quickly kill it. Or it may have been because it withers so soon after being cut.

Look now at the clusters of spore cases. These are fronds of another kind. They are shorter than the others. If you examine them carefully you will see that they are made up of leaflets just as the large 46 


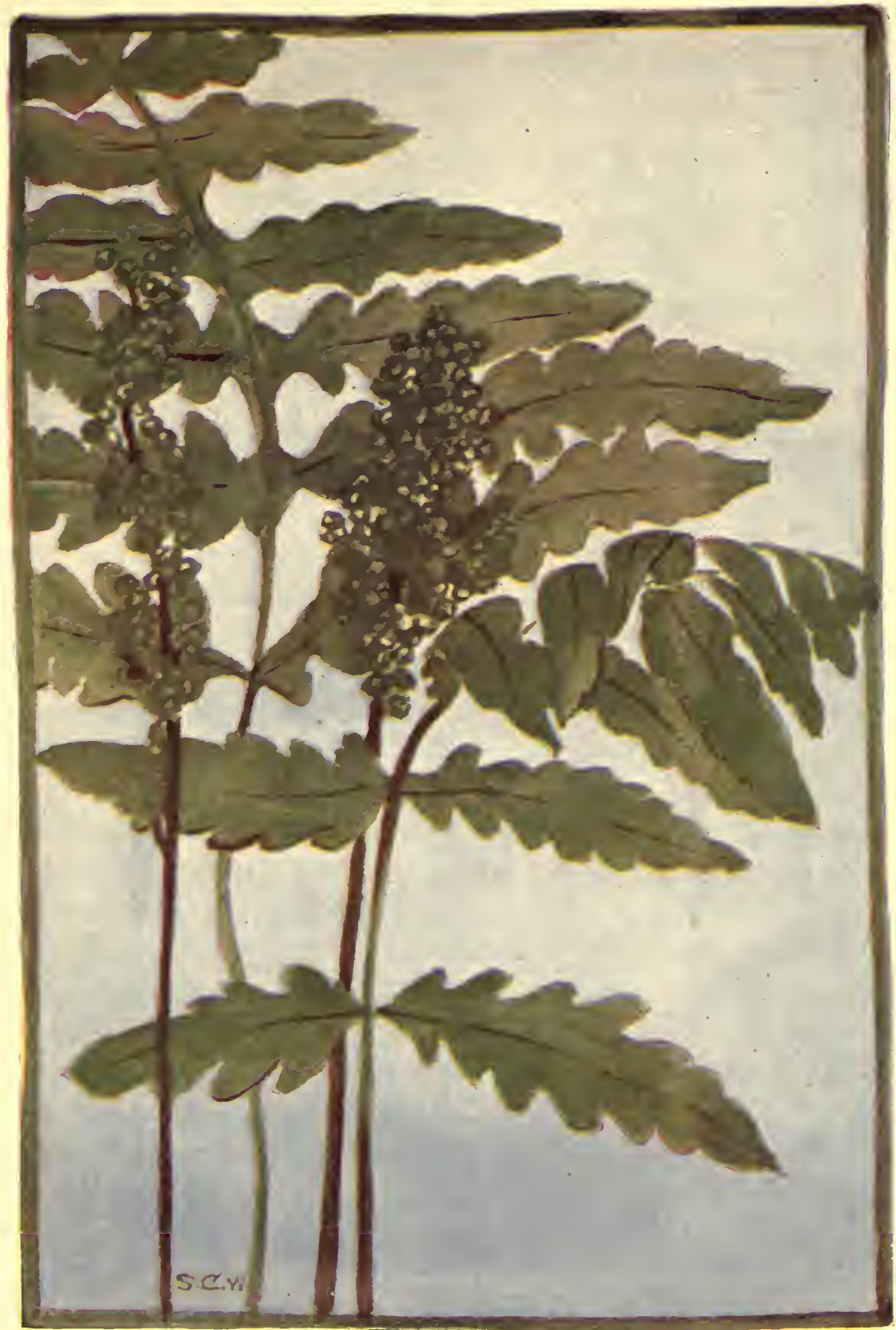

The Sensitive Fern. 


\section{THE SENSITIVE FERN}

green fronds are. These leaflets look like little green berries strung along the stems. They are so closely rolled that one author in speaking of them says that most ferns hold their spore cases in the open hand, but the sensitive fern grasps them tightly in the clenched fist. When the little pods are ripe they burst open and the spores escape. But the fronds remain erect until the next summer.

If we had walked along the banks of this stream in the spring we should have seen our ferns in a very different dress. A mass of tawny pink crosiers would have nodded to us as much as to say, "How do you like our looks?" If you had then picked some and examined them, you would have wanted to reply, "I like your looks very much," for you would have found much beauty in the uncoiling pink blades.

The sensitive fern loves the sunshine. While it will grow in the woods it very rarely bears spores there. 'The plants that we have found in the shade have had small fronds. They looked quite different from the large, coarse plants growing in the sun.

Some very old books speak of this fern as dragon's bridges. Isn't that a queer name? No one seems to know why it was so called.

The sensitive fern is found in nearly all parts of the United States east of the Mississippi River, and in a few places west of it. It also grows in Japan. 


\section{FERNS}

Full-veined and lusty green it stands,

Of all the wintry woods the gem;

Our spirits rise when we discern

The pennons of the Christmas fern.

With holly and the running pine

Then let its fronds in wreaths appear,

'Tis summer's fairest tribute given

To grace our merry Yuletide cheer;

Ah, who can fear the winter stern

While still there grows the Christmas fern."

\section{SPINULOSE WOOD FERN}

As you may see from its name, this fern grows in the woods. It likes the shelter of rocks and large trees. There are several different forms. All of these have stiff brown scales or "spines" along the stipes. These give the fern its name of "spinulose."

The fronds are a rich green. They spring up in circles from fallen trees and decayed stumps, as well as from the ground. The leaves are so finely cut that they give a delicate lacelike look to the plant. When young they are often very sticky on the under side.

The spore-bearing fronds are apt to be somewhat taller than the others. You can see the fruit dots on the back of the longer frond in the picture. If you 


\section{SPINULOSE WOOD FERN}

were to look at this leaf through a magnifying glass, you would find that these dots were in double rows on each of the leaflets. They are round, but they have a kidney - shaped covering. The spore cases are peeping out from under the edges of this.

All forms of the spinulose fern are evergreen. The fronds turn brown early in the spring. One variety is much used by florists in making up designs. They use this and the Christmas fern more than any others. A New

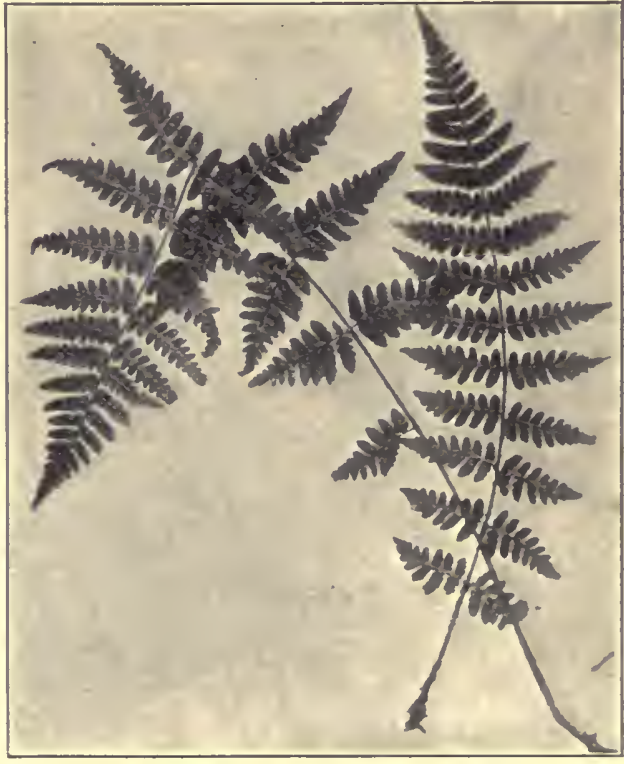

The Spinulose Wood Fern.

Orleans florist says that they are sent South by millions and kept in cold storage until wanted.

Another form is very common in Alaska. Its rootstock is the first vegetable food that the Alaska Indians are able to get in spring. They dig it before the fronds spring up and bake it in pits lined with hot stones. It is said to have a sweetish taste, but that 


\section{FERNS}

white people do not like it. It is too smoky and tastes too much like tobacco to suit them.

This plant is very easy to cultivate. It grows beautifully in the house among other ferns.

\section{THE COMMON POLYPODY}

Among all our ferns there is probably none more common than the polypody. It will grow almost anywhere. It likes best, however, the top of a shaded ledge of rocks where the soil is somewhat dry.

You can see in the picture how slender the brown rootstock is. This creeps along near the surface of the soil. It was because this rootstock had so many branches that the fern received the name of polypody, which means "many feet." The spreading branches seem to bind the plants together as they almost hang over the rocky ledge. These ferns, thus bound together, have been compared to people who are climbing the mountains and are kept from falling by a rope which ties them together.

The young fronds appear in the spring. Others come up during the early summer. They are from four to ten inches long. You can see in the picture how the leaf is divided. The deep-green frond is thick and leathery. This helps the fern to live through long periods of dry weather. Even in midsummer the 


\section{THE COMMON POLYPODY}

leaves keep their freshness and color. Sometimes they curl up if there is no rain for a long time. A good shower will soon revive them. The polypody seems to make the most of every drop of moisture.

About the middle of June the bright yellow - b row fruit dots begin to appear. A month later they are well grown. You

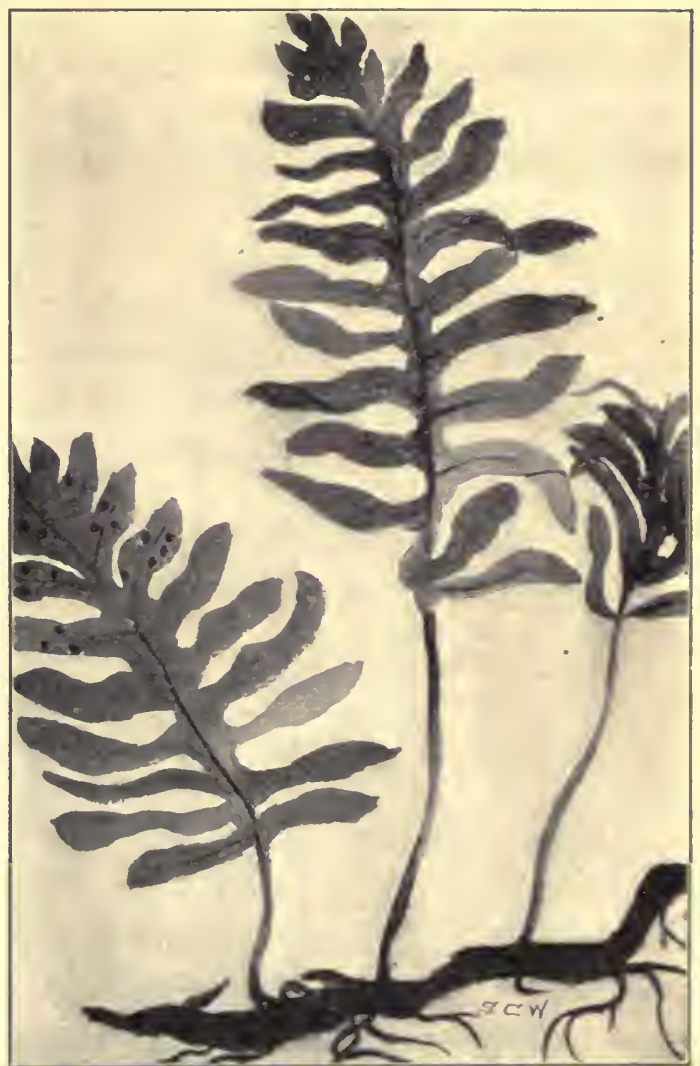

The Common Polypody.

can see them upon the back of one of the fronds. They are generally near the margin, and mostly on the upper part of the frond. These fruit dots are round and very large. They have no covering. 


\section{FERNS}

When winter comes the polypody still carpets the rocks with its cheerful evergreen fronds. If, at this season, you visit the woods where it grows, you will find it green and full of life, as if defying the frost. The poet says:

"And there, though shaken by wind and storn,, The glint of her fronds is seen

As she wreathes about the lichened stone A circle of delicate green."

The picture that you see is from a plant found on Long Island during the month of December.

\section{THE RUSTY WOODSIA}

WHILE wandering about through the woods at Roger's Rock, Lake George, we found a number of dainty little ferns. Among them was the rusty woodsia. Tufts of this fern grew on the top of the gray rocks overlooking the lake. There was not much depth of soil, so the plants had little moisture. Scattered trees here and there allowed the sun to peep in.

This little fern loves to grow on rocks. The dense tufts or masses in which it grows help to give it moisture. About an inch above its base the stipe is 54 


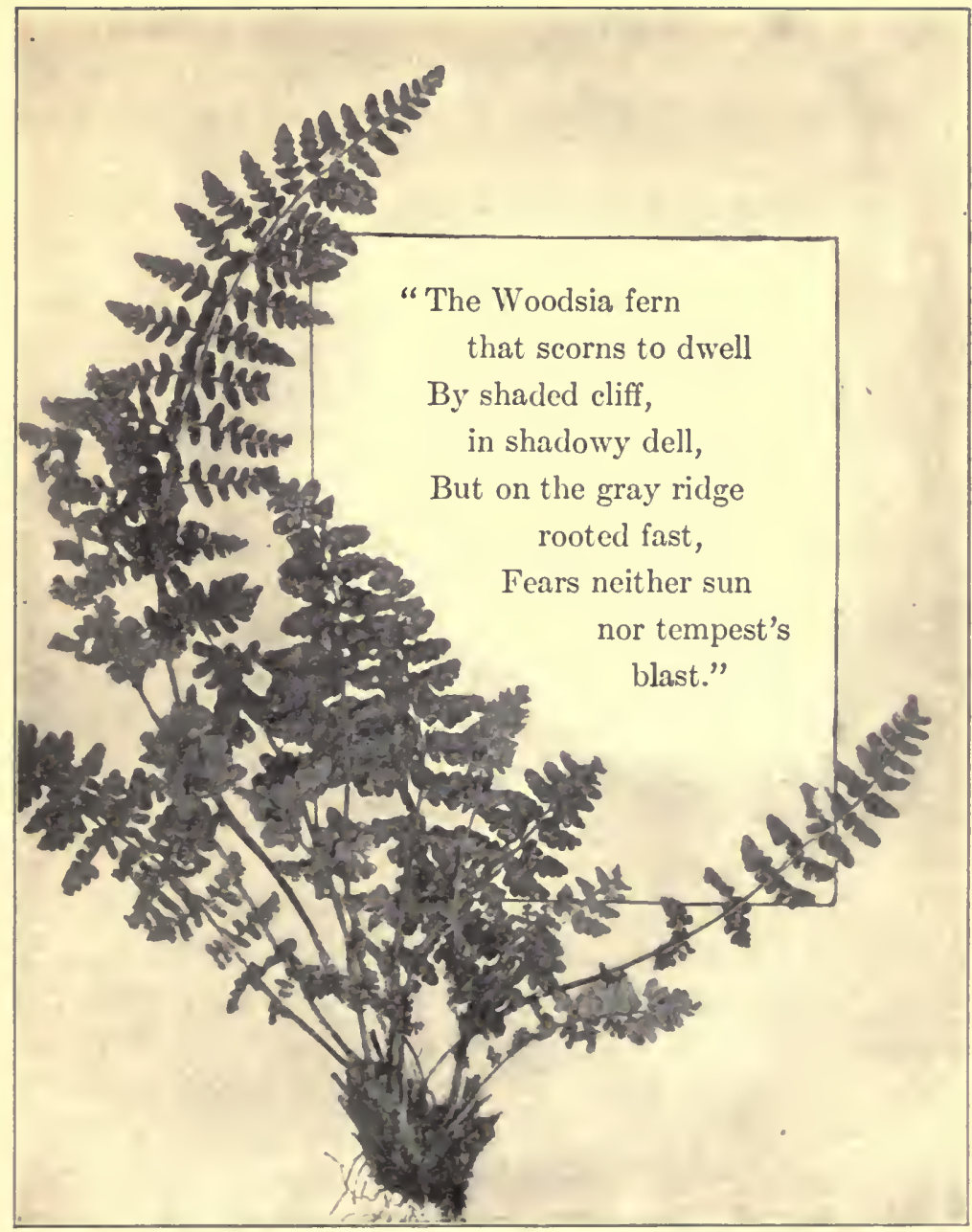

The Rusty Woodsia. 


\section{FERNS}

jointed. When a frond dies it breaks off at this joint. The bases of the old stipes, standing together, make a trap to catch all the particles of soil that are brought along by the wind. These, together with the masses of rootstocks and rootlets, hold the moisture as long as they can.

The leaves, also, are made to keep moist for some time. They are smooth above, but on the under side of the frond, where the breathing pores are situated, there is a scaly covering. This prevents the moisture from going off too rapidly. In May, when the fronds uncoil, the scales are almost white; but they soon turn to the color that has given the fern its common name.

The fruit dots are round. Their covering consists of a few slender hairs which curve over the spore cases when they are young. On old fronds the under side is so woolly that the fruit dots are almost concealed.

This is a pretty little member of the rock-loving family of ferns. Look for it on the rocks when you visit the woods. It is well worth searching for as it stands

"Content above the world to brood In silence and in solitude" 


\section{THE EVERGREEN WOOD FERN}

\section{THE EVERGREEN WOOD FERN, OR MAR- GINAL SHIELD FERN}

Axотнer fern found at Lake George is shown in the picture. This is an evergreen wood fern. As it grew on the rocks where the soil was not deep the fronds are rather small. Notice what a large root there is for so small a plant. No other wood fern has so heavy a rootstock. Do you see the long, chaffy scales along the stem and on the rootstock? These are always found on this kind of fern.

The fronds are thick, almost like leather. They are

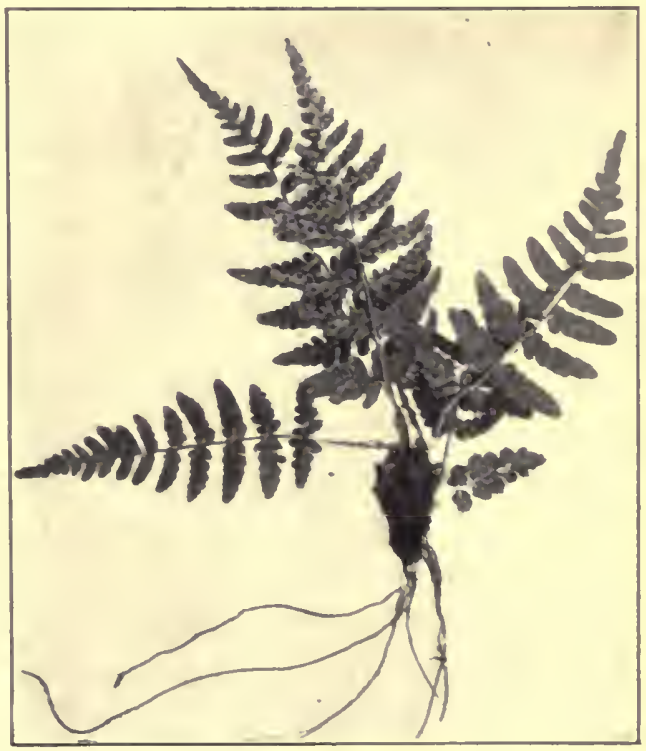

Evergreen Wood Fern.

of a dark bluish-green color and are lighter on the under side. As is shown by its name, these fronds remain green through the winter. But they do not 


\section{FERNS}

stand erect. In the fall the stipes get weak at the base, and the fronds bend over to the ground.

The fruit dots of this fern are on the margin of the leaflets. See how close to the edge they cling. Often they look as if pushing out beyond it. Because of this the plant is sometimes called the marginal shield fern. When the fruit dots are young, they are hidden by a white or gray covering. This does not wither as soon as it does in most ferns.

This is an American fern. It is found from Canada southward to Alabama and Georgia.

\section{FERNS IN STONE AND COAL}

If you were to visit some of the coal mines of our country, you might find pieces of coal upon which there were very distinct fern-leaf shapes. These same forms are often seen upon stones that are taken out of quarries. They are called fossils. Here is a picture of a piece of stone that has some of these plant forms. You can see that none of the fronds are perfect. Very seldom is an unbroken leaf found.

How do you suppose that ferns got inside of these masses of coal and rock? Men have learned that coal is made up of plant material. From this, they know that coal beds are not like other rocks; but'that at some time there was a mass of plant life here. As 


\section{FERNS IN STONE AND COAL}

many fern fossils are found, there must have been a great number of those plants. Some of them were very large, much larger than they grow now.

It must have taken a long time for the coal to become such a hard mass. It was certainly thousands of years ago that these ferns grew. Let us see how they changed, and why the forms of these plants can be so distinctly seen.

Did you ever step into soft, wet mud and find that the shape of your foot was left there? That was because your foot was harder than the mud. This is what prob-

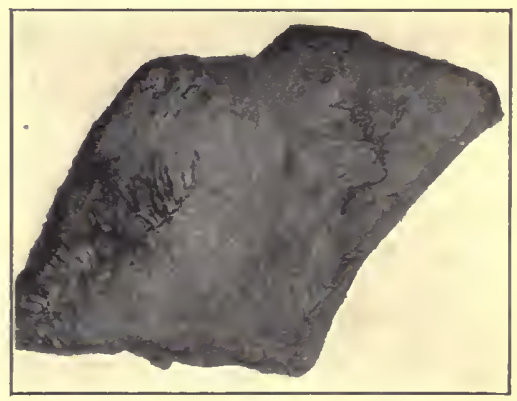

A Fern changed to Coal. ably happened to the masses of plants. They formed at first a thick mat of rushes, ferns, and trees. Then water flowed over these beds, and mud, sand, and gravel settled there. At length these formed thick layers on top of the plants. They gradually pressed down close upon the mass below, and there hardened into stone. The ferns and other plants left their forms upon this rock wherever they were pressed against it. Under this layer of rock the plant mass, packed down, and kept warm, but without light, gradually changed to coal. 


\section{FERNS}

"In a valley centuries ago

Grew a little fern leaf green and slender,

Veining delicate and fibers tender,

Waving when the wind crept down so low;

Rushes tall and moss and grass grew round it,

Playful sunbeams darted in and found it,

Drops of dew stole down by night and crowned it.

But no foot of man e'er came that way

Earth was young and keeping holiday.

Monster fishes swam the silent main,

Stately forests waved their giant branches,

Mountains hurled their snowy avalanches,

Mammoth creatures stalked across the plain;

Nature reveled in grand mysteries;

But the little fern was not of these,

Did not number with the hills and trees,

Only grew, and waved its wild sweet way;

No one came to note it day by day.

Earth one time put on a frolic mood,

Heaved the rocks, and changed the mighty motion

Of the deep strong currents of the ocean;

Moved the plain and shook the haughty wood,

Crushed the little fern in soft moist clay,

Covered it and hid it safe away.

Oh, the long, long centuries since that day!

Oh, the changes! oh, life's bitter cost!

Since the useless little fern was lost. 


\section{FERNS IN STONE AND COAL}

Useless? Lost? There came a thoughtful man Searching nature's secrets far and deep;

From a fissure in a rocky steep

He withdrew a stone o'er which there ran

Fairy pencilings, a quaint design,

Leafage, veining, fibers clear and fine,

And the fern's life lay in every line." 


\section{MUSHROOMS}

WE are now going to read about mushrooms, or toadstools. Perhaps you will like them the best of anything in this book. It seems almost strange to call them plants - they have no separate root, stem, or leaf. They are not green, nor are they the shape of other plants. Such plants are called fungi. People who have studied them, however, find that fungi grow somewhat as other plants do, and that they bear spores from which we get new plants.

Like the ferns and mosses, mushrooms are found everywhere. In the woods, you may see bright-red, orange, or yellow toadstools peering out from among the dead leaves at your feet. Tall gray, brown, or white , ones are seen here and there growing around the roots of trees and stumps. Dense clusters of them grow out like brackets on the trunks of standing trees. Others may be seen on the fallen logs which lie across the path. Some looking like branches of dainty coral light up the wood with their pink or golden coloring.

In the cattle pastures and along the roadside they are the companions of the ferns, the mosses, and the flowering plants. On the lawn we find them springing 


\section{MUSHROOMS}

up in clusters or circles, especially in damp weather, or after a heavy rain. Even the garden is not free from them, and they are often found in damp cellars and mines. Sawdust is also a favorite place for fungi to grow.

It is not their coloring alone that makes mushrooms so pretty. They are found in all sorts of odd shapes, as umbrellas, balls, nests, cups, clubs, hoofs, shells, and hemispheres. The picture shows you some of these. But there are other forms that are less pleasing. The mildew on linen the mold on bread, the rust and smut that spoil grain and

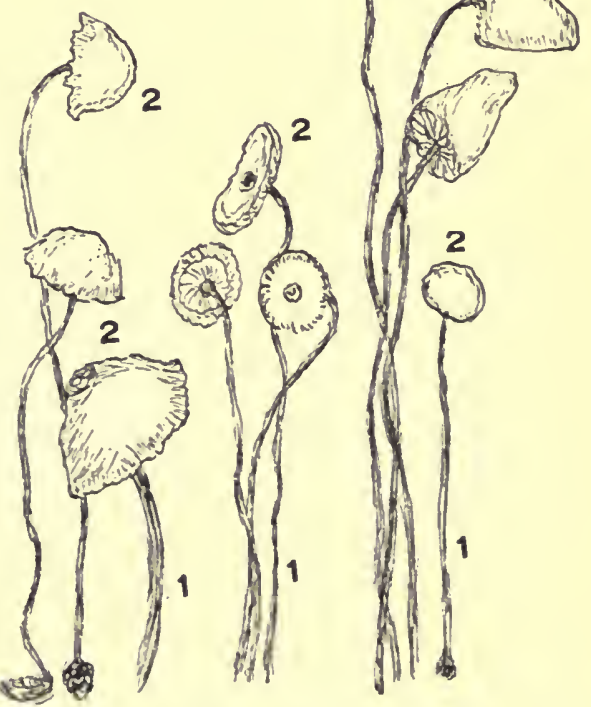

Mushrooms Showing Difference in Shape of Caps. 1, Stipe or Stem; 2, Cap. corn, are forms of fungi which we do not like.

The mushrooms found in the woods and fields feed upon decaying wood and leaves. They must have food on which to grow, just as we must have food to make 


\section{MUSHROOMS}

us large and strong. They have no leaf green, so they must feed on material which has been made by green plants.

People who have studied fungi have placed them in three classes. The first is a cobwebby plant, and includes the bread mold, the potato rot, and the fungus which grows on fishes and makes them die. First we see fine white threads

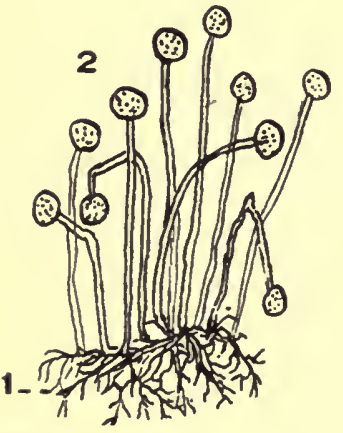

The Bread Mold. 1, Fine Threads that form the Plant; 2, Spore Cases.

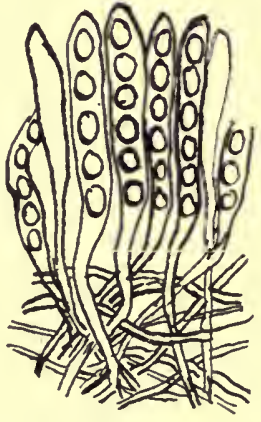

Spores in Sacs.

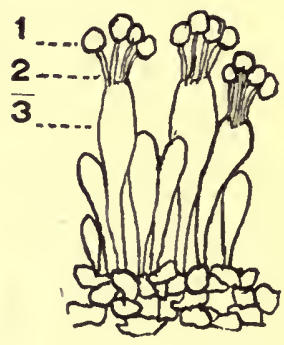

Spores on Little Stalks Standing in Large Cells. 1, Spore Cases; 2, Stalks on which Spore Cases Grow; 3, Cell out of which the Stalks Grow.

which form the plant. Later there are spore cases holding tiny black spores. As their number increases, they form a disagreeable black mass which destroys the life of that upon which it lives.

The second class form spores in delicate sacs. Among these is the yeast plant by which our bread is raised. The fungus which makes the peach leaves curl, 


\section{PARTS OF A MUSHROOM}

and puts black knots on cherry and plum trees, is of this kind.

In the third class are all the fungi which bear their spores on little stalks standing up in large cells. This class contains most of the mushrooms that we find in the woods and fields. It is about these that we are going to read. When you pick them you call them toadstools. When they are cooked and given us to eat we speak of them as mushrooms. Yet they may be exactly the same.

\section{PARTS OF A MUSHROOM}

MAvy mushrooms look like parasols or umbrellas. The handle is the stem, or stipe. The open top is the cap, or pileus. The cap is the first part to be noticed. It is often very bright-colored. The size of the cap varies from an eighth of an inch to sixteen inches or more across. The outside may be smooth, or it may be covered with little scales. Sometimes it shines like satin. Notice how the caps of the small mushrooms on this page differ in shape.

The cap is held in place by the stem which grows up out of the ground, or out from a tree or stump. Sometimes this stipe is joined to the cap in the middle; often it is at the side. Frequently there is no stem. In this case the cap grows squarely against the surface of a tree 65 


\section{MUSHROOMS}

or stump. Sometimes the stems are of solid flesh all the way through. Others are hollow, like a piece of rubber tubing. The stem is often brittle and breaks easily. In other plants it is impossible to divide it evenly in breaking.

When the plant is young, the edge of the cap lies

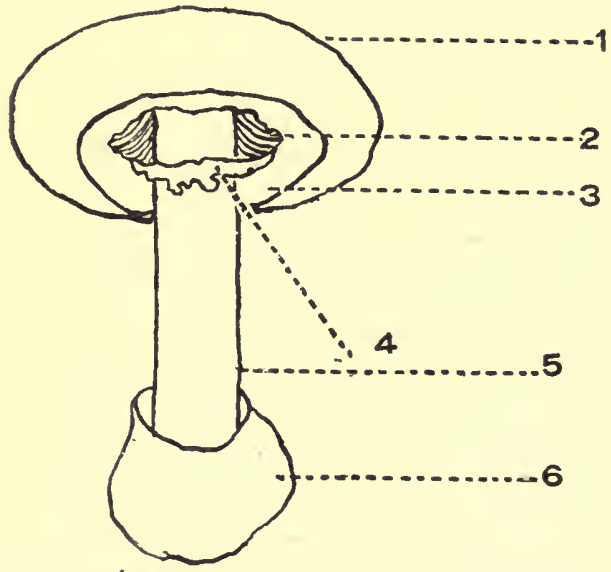

Parts of a Mushroom. 1, The Cap or Pileus;

2, The Gills Where Veil is Torn; 3, The Veil; 4, Part of Veil Remaining on Stem. This Forms the Ring or Annulus; 5, The Stem, or Stipe; 6, The Volva or Cup. close to the stem. In some mushrooms, the cap spreads out without ever being fastened to the stipe. In others, threads grow from the edge of the cap and from the outer layer of the stem. These interlace and form a delicate veil which closes the space between the cap and stipe. The veil remains firm for a while but is finally torn by the opening cap. Its remnants are left for a time as a ring on the upper part of the stem, or else parts of it hang in flakes from the edge of the cap.

Examine a mushroom of this kind, and you will see 66 


\section{PARTS OF A MUSHROOM}

that on the under side of the cap, reaching from the stem to the edge, there are thin plates or gills. When

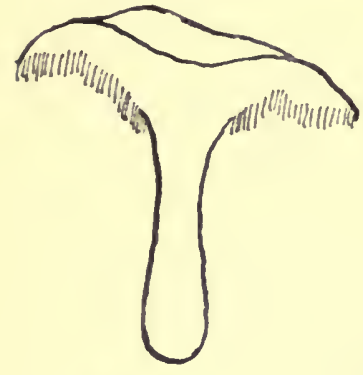

Mushroom with Gills.

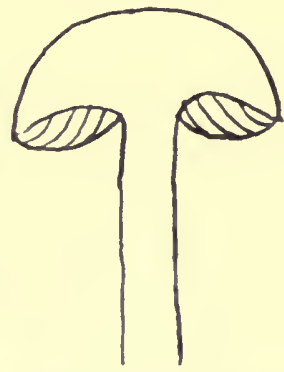

Mushroom with Tubes; or Pores.

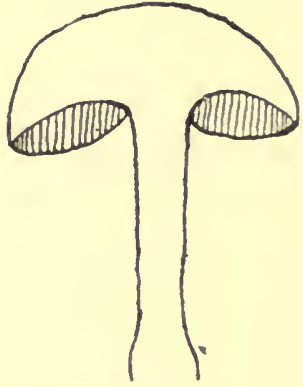

Mushroom with Teeth.

the plant is young the gills cannot be seen. They are hidden under the veil. As soon as this breaks they come into sight. It is on the surface of the gills that the spores are formed. When they are ripe they fall to the ground and grow into mushrooms, as you will learn in the next chapter.

If you wish to see these spores, cut off the stem of the mushroom and place the cap, gills downward, upon a piece of paper. Choose a plant with dark gills and use white paper. Cover with a glass

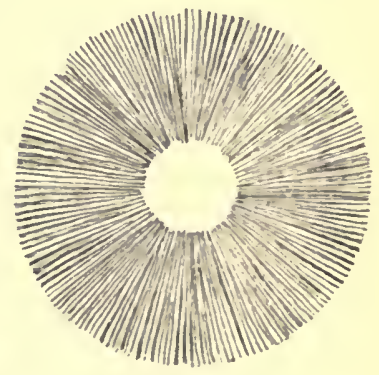

Spore Prints. so that the wind cannot touch it. In a few hours remove the glass and lift the cap carefully. You will 


\section{MUSHROOMS}

probably find the spores on the paper in the form of the gills, as you see in the picture on this page.

There are some mushrooms that have in addition to the cap, gills, stem, and ring, a part somewhat like a cup. This is at the lower end of the stem. From it the stem appears to spring. This is the volva. It is sometimes called the "poison cup" because it is found on some of the most poisonous mushrooms.

\section{HOW MUSHROOMS GROW}

You have already learned that all forms of fungi are spore-bearing plants. But how do these queer-looking

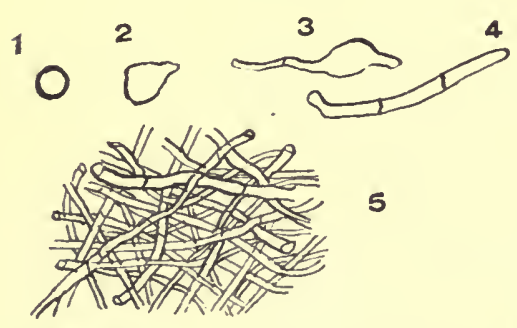

How Mushrooms Begin to Grow. 1, A Single Spore or Cell; 2, A Spore, or Cell, Grown Larger; 3, A Spore Divided into Two Cells; $4, \mathrm{~A}$ Chain of Cells; 5, A Tangled Mass of Cells (called Spawn).

plants grow from spores? A spore has but one cell. This cell can absorb food through its walls. When the spore falls in a warm, moist place, it begins to take in food and grow. Then it divides into two cells. Each new cell divides again, until long chains of cellsareformed. These look like threads. Soon they form below the surface of the earth a tangled mass called the my-ce'li-um, or spawn. The mycelium feeds on the 68 
decaying vegetable substance around and spreads through the soil somewhat as the rootstock and rootlets of ferns do.

After a while the threads mat together at certain places and form little balls. At first these are about as big as the head of a pin. They grow larger until they are the size of a shoe button. If the ball is to become a toadstool

a stem appears.

The stem and the button keep on growing and soon the button comes out of the earth. Then it expands and we see our acquaintance, the toadstool.

If the button

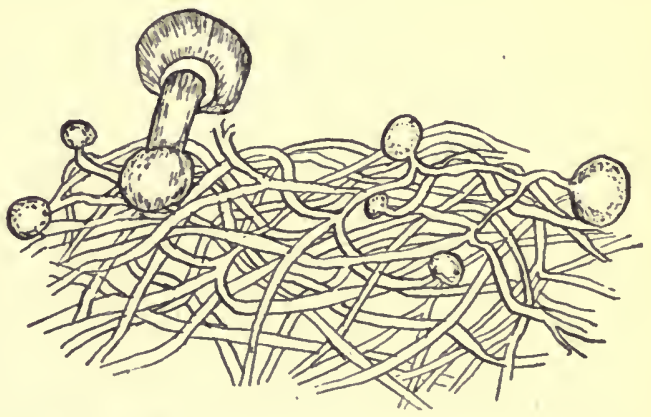

Spawn, or Mycelium. Shows Button Stage and Young Mushroom with Parts Complete. is to be what is known as a puffball no stem appears. It grows into a round ball covered with a skin or rind. Sometimes the part that springs out of the earth stands erect and sends out many branches. Then it looks like a piece of coral. Or it may be shaped like an Indian's club. This plant is four or five inches tall and is blunt and rounded at the end.

Some fungi grow in trees instead of in the ground. The mycelium gets into the tree through wounds where 69 


\section{MUSHROOMS}

branches are broken off. Here it lives and grows for years, gradually taking the life from the tree and causing it to decay.

When people wish to grow mushrooms they plant the mycelium, or spawn. The growth from spawn is much quicker than from spores.

\section{THE COMMON MEADOW MUSHROOM}

The common meadow mushroom is the best known of the fungi. It is found for sale in many markets. The picture shows you a cluster of these plants as they grow among the meadow grass. Though this is their favorite dwelling place, they are sometimes found on the lawn, in the garden and pasture, and by the roadside.

The thick, fleshy cap is rounded, and is usually white or light brown. The surface is smooth and a little silky. Sometimes it is torn up into'scales. These scales are often of a dark color.

The most important thing to notice in this plant is its gills and their color. As the cap expands, and the veil breaks, we find them to be of a delicate pinkish tint. When they grow older they change to a smoky brown. This is because of the great number of dark-colored spores that are borne on their surface. No poisonous mushrooms are known whose pinkish spores turn brown 
as these do. The gills are close together and are rounded at the stem end. They curve up to the cap.

The stem is short and is about the same size from top to base. It is quite solid-perhaps a trifle softer in

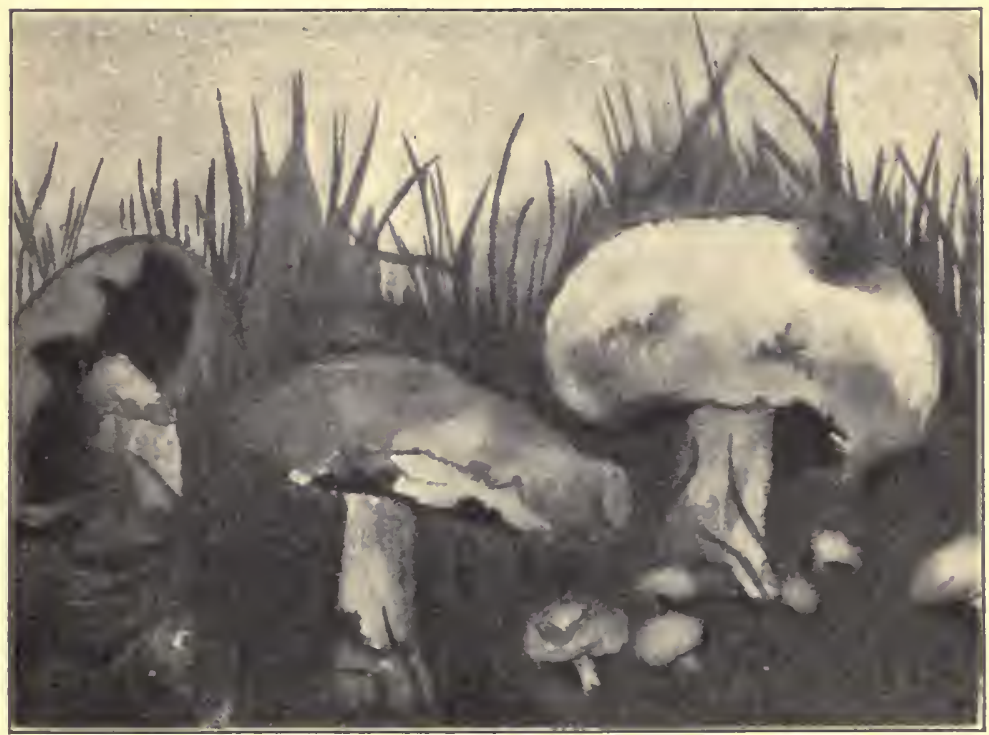

The Common Meadow Mushroom.

the middle than near the surface. It is easily separated from the cap.

The veil is white and silky. It is thin and very frail. It stretches as the cap spreads out and is finally torn so that it clings as a ring around the stem. This ring is so delicate that it is easily rubbed off. A rain 


\section{MUSHROOMS}

will often wash it away. Sometimes pieces of the veil hang around the edges of the cap.

The flesh is white, but it may become slightly tinged with red when cut and exposed to the air. Its taste is pleasant, somewhat like that of a nut.

This is the plant that is generally spoken of as "the mushroom." Probably because it is the only fungus that has been cultivated to any great extent. Generally the mushroom or toadstool refuses to be coaxed into growing anywhere except in its native place. "They will not emigrate; they refuse to be educated, and stand themselves upon their single leg, as the most independent and contrary growth with which man has to deal." But the common mushroom, when carefully transplanted and cared for, will reward its cultivator with an abundant crop.

There is a plant known as the horse or field mushroom that is very much like the common meadow mushroom and grows in about the same places. It is somewhat larger. The stem is hollow, and larger at the base than at the top. Near the cap is a double ring or collar the lower part of which is thicker than the upper. As it is good to eat, there is no harm done if we cannot always tell it from the common mushroom. 


\section{THE FAIRY-RING MUSHROOM}

Here you see a leathery little toadstool that shrivels up when dry, but becomes soft again when moistened by rain or dew. It is common in grassy places, such as lawns, roadsides, and pastures. The plants may be seen from May until October.

The cap of this mushroom is from one to two inches broad. When young it is tawny or reddish, but it becomes paler as it grows older. When dry it is usually a light yellow or buff. In the older plants the center of the cap is often raised in a distinct tiny mound. You can see this in the picture.

The gills are somewhat broad and far apart. Their color is the same as that of the cap, or lighter. The spores are white.

The slender stem is from one to two and a half inches long with a smooth surface. It is solid and quite tough. The color is whitish or a creamy yellow.

This mushroom usually grows in rings or circles. It was once thought that the elves made the mushroom rings for their moonlight dances. This is the reason that it was called the "fairy-ring" mushroom.

Many are the tales which were told by the "old folks" in some parts of England and Scotland about travelers who were seized by the fairies and carried off 


\section{MUSHROOMS}

to join in their dances within the "mystic circle." On pleasant nights these little people sat or danced on the top of the toadstools. If a sudden shower came on they huddled together beneath them. One old gardener declared that he had seen the fairies holding a

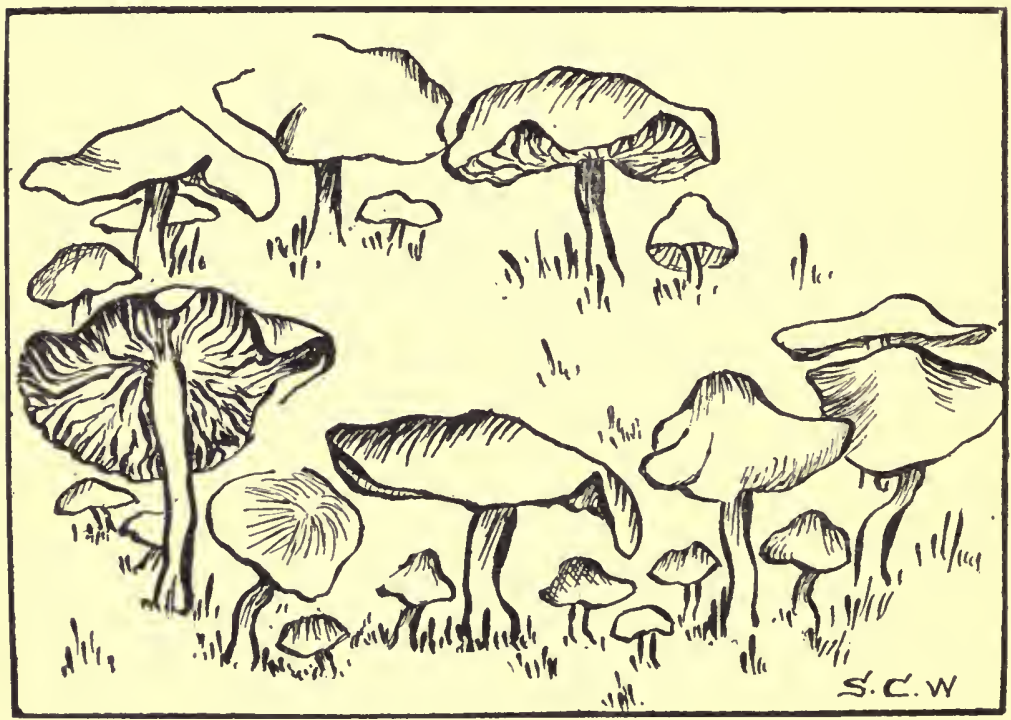

"These are the tents of the fairies

That camped last night on the lawn.

Early this morning I found them,

But the sly fairies had gone."

toadstool over their fairy queen for an umbrella, as she tripped home in the rain. 
Another story is told of a fairy feast in which-

"A little mushroom that was now grown thinner By being at one time shaven for the dinner"

served for a table.

This is not the only fungus that appears in circles. Several different kinds are said to grow in this way. The reason that fungi grow in rings, is because of the way that the mycelium grows. At first there is a single mushroom. This uses up the soil so that the plant will not come up in the same spot again. But the spawn spreads, and the next year sends up plants in a small ring outside the place where the one grew the year before. Again the mycelium spreads and the spores fall. In this way the size of the circle increases each year.

For a long time the "fairy-ring" mushroom has been used for food. It is small, but in some places bushels may be gathered in a day. It has an agreeable nutty taste.

Mr. Hamilton Gibson said: "I remember, as a boy, summer after summer, observing upon a certain spot upon our lawn this dense, and at length scattering, ring of tiny yellowish mushrooms, and the aroma, as they simmered on the kitchen stove, is an appetizing memory." 


\section{MUSHROOMS}

\section{THE BOLETI}

If you look on the under side of this mushroom for gills you will not find them. It is one of those plants that have their spores inside of tubes or pores. All such mushrooms are called pol'y-po-ri, or "many pores."

A great number of these fungi are found on the trunks of trees, where they grow larger and larger each year. But this mushroom did not grow on a tree. It came up out of the ground, just as the common meadow mushroom and the fairy-ring did. Instead of springing up in the grass it grew under the trees in the woods, where we found it during the month of July.

While this fungus belongs to the order of the Polypori, it is called also the boletus. If we speak of a number of these plants together we call them the boleti.

The cap of a boletus is soft and thick, like a cushion, and feels like velvet to the touch.

The plant in the picture is known as the edible boletus. It is white and firm and somewhat sweet. The young plants taste like raw chestnuts.

The upper surface of the cap of the edible boletus is brown. The tube part is white when the mushroom is young. Later it becomes yellow or a yellowish green. 


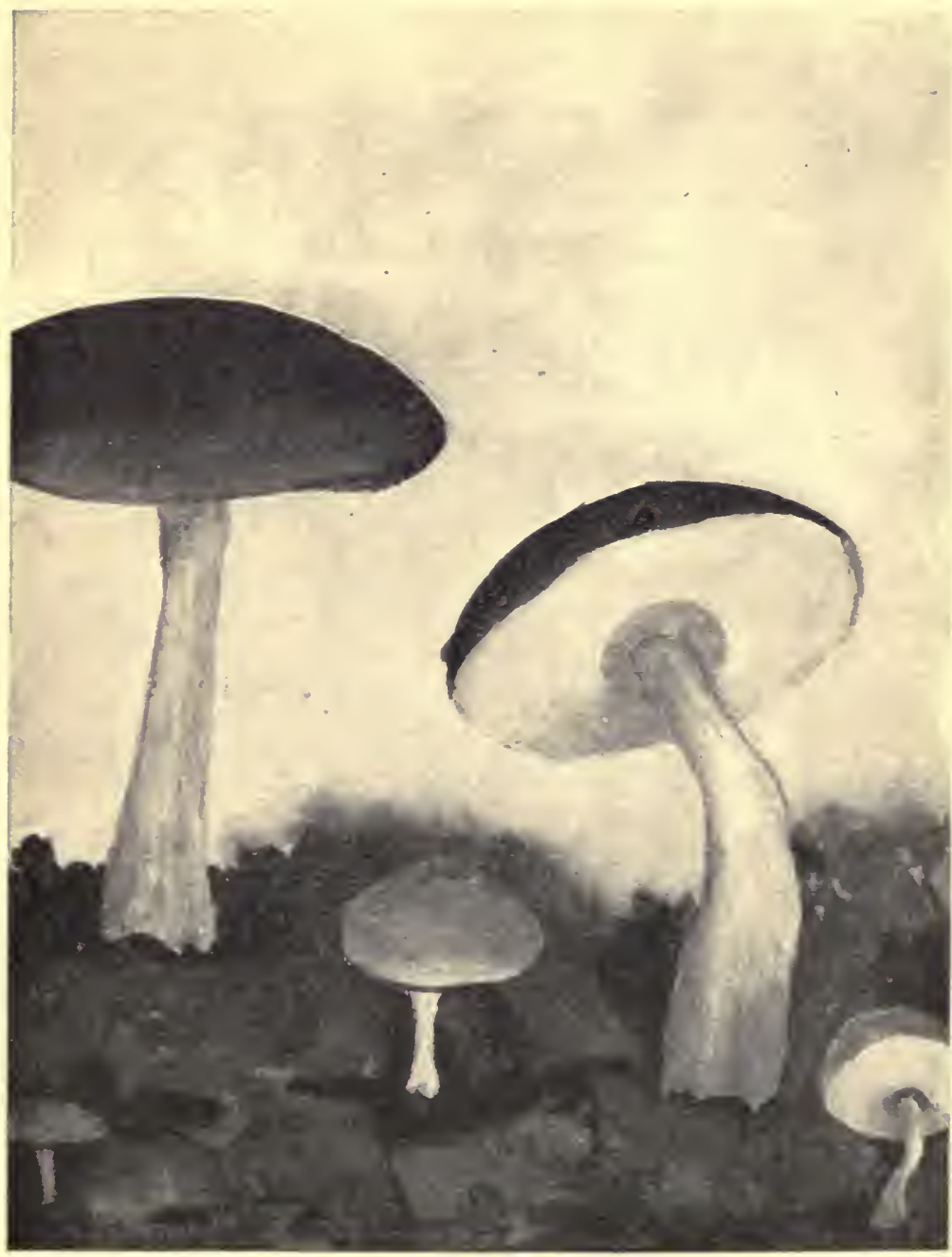

The Edible Boletus. 


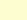




\section{INK CAPS}

The stem is long and largest at the base. It is pale brown in color and generally has a network of pink lines. As it is apt to be tough and stringy, it should be cut out when the plant is cooked.

These mushrooms are often dried and used for flavoring. They are also eaten raw with pepper and salt.

It is best to be very cautious about the use of these plants. None that have not been pronounced safe by good authority should ever be eaten.

In color, the boleti are crimson, green, or yellow. A strange thing about them is the way that they change color when cut, broken, or bruised. In some, the flesh becomes red inmediately, while others turn blue or a bluish green.

\section{INK CAPS}

Ox some summer or autumn morning you may find, on the lawn, a crowded mass of odd-looking mushrooms. A few hours later the tall stems may be standing, but the caps are broken or melted away. An inky fluid is, perhaps, still dropping from them.

These plants are ink caps and are sometimes called "inky toadstools." The stem is slender, smooth, and hollow. The cap is of a gray color. The gills are broad and lie closely packed side by side. When young they are a creamy white, but later they turn to a pinkish 


\section{MUSHROOMS}

gray. When the spores begin to ripen they turn black and the color of the gills changes. The cap now begins to expand and to turn into an inky fluid, first becoming dark and then melting into a black liquid. This melt-

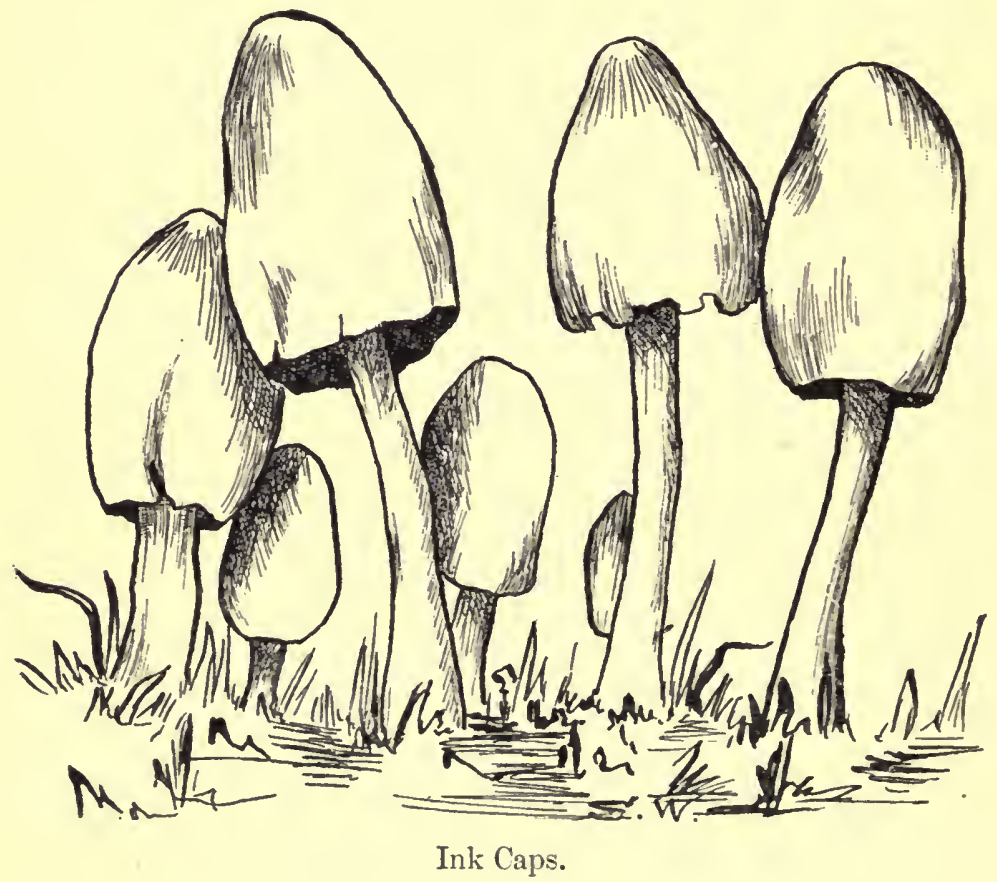

ing mass forms into drops which fall from the margin of the cap. The extreme outer surface of the gills does not dissolve so freely, and the thin remnant curls upward and rolls up on the top of the cap. 
We had a number of these plants in the garden, and several efforts were made to keep them. The results may be seen in this picture. The only way in which they could be kept was to put them behind glass, where nothing could touch them.

Does it not seem strange that such blacklooking things should be good to eat? Yet, they are pronounced excellent by mushroom lovers. They should be picked when very young and cooked as soon as they are brought into the

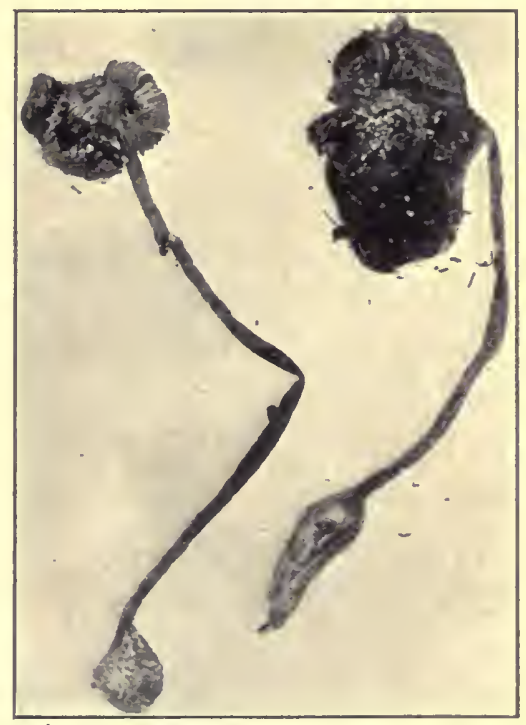

Ink Caps Dried. house. A very fine catchup is made from these plants.

The black fluid is sometimes used for ink, but it is not considered a very good article.

\section{THE AMANITA FAMILY}

DiD you ever find a beautiful plant or some pretty bright-colored berries, and hear mamma say that you must not touch them because they were poisonous? 
The picture on the opposite page shows you four mushrooms of the Am-a-ni'ta family. These, like the poisonous berries, should be let alone. Though they are among the most beautiful of fungi, most of them contain a deadly poison.

Notice the tall, light-colored one. This is sometimes called the Death Cup or The Destroying Angel. It

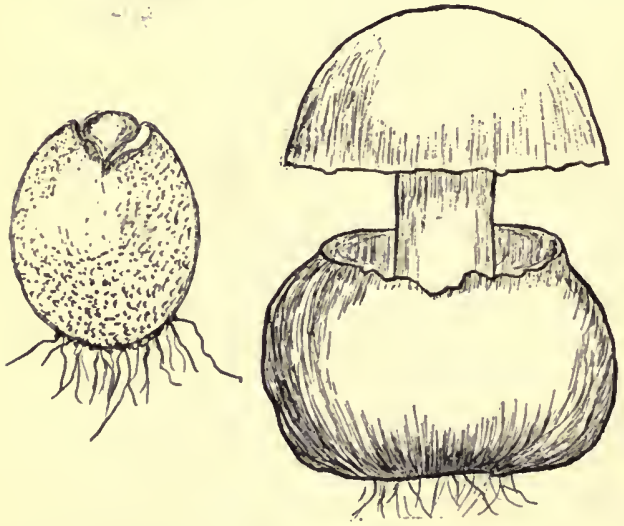

Young Plants of the Amanita Family. contains the same poison as that of the rattlesnake and other venomous animals.

This plant is found from June to October. It looks so much like some of the mushrooms that are good for food, that it is often picked and eaten by mistake. Look at the base of the stem of a mushroom before picking it. If it belongs to the Amanita family, there will be a cup or socket either just above the soil or hidden under the ground. This is known as the poison cup, and all fungi having it should be avoided.

It is not safe even to handle these mushrooms. Mr. Palmer, who was well acquainted with all kinds of fungi, 


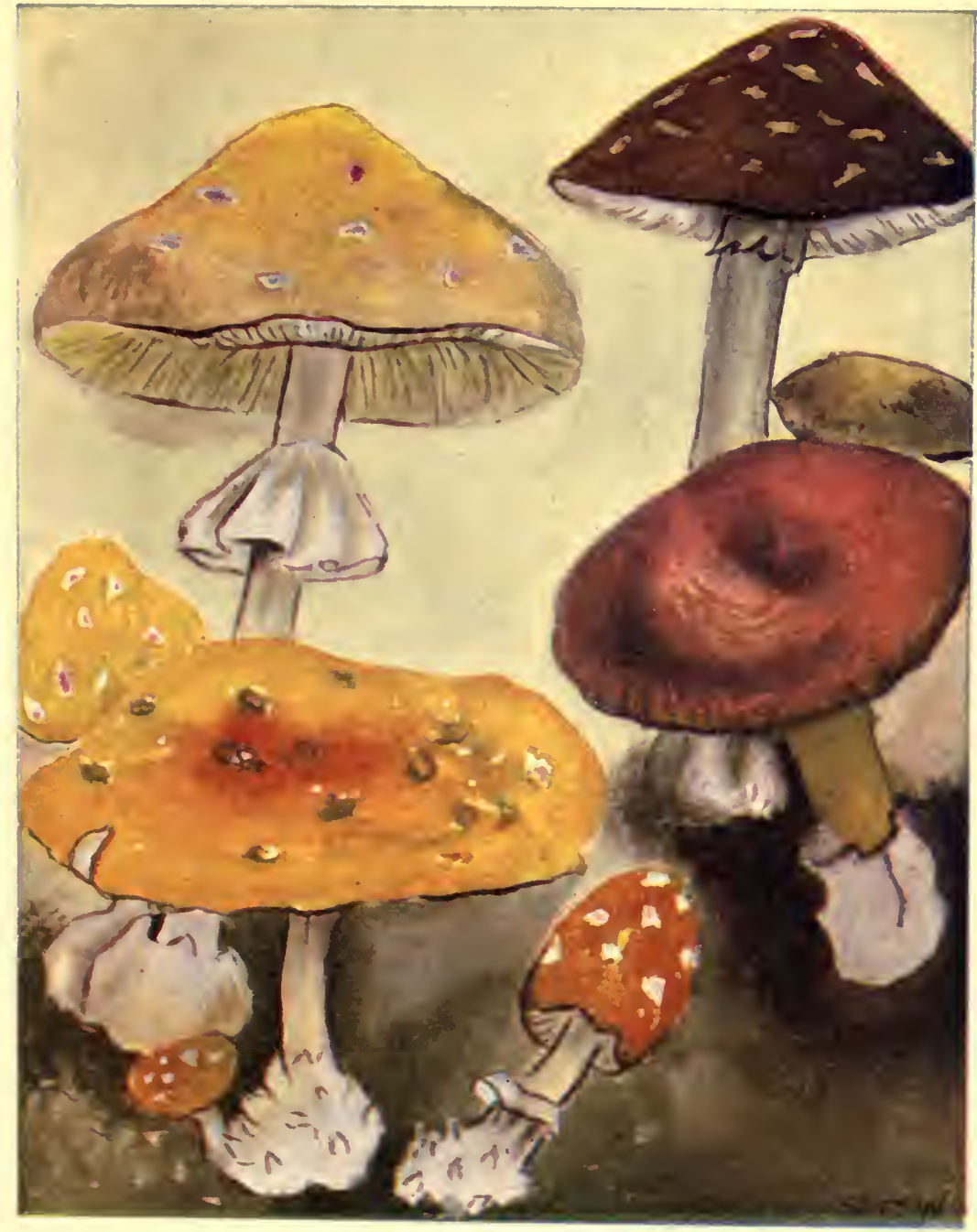

Members of the Amanita Family. 
. 


\section{MUSHROOMS}

tells of taking a large bunch of Amanitæ to an artist friend. He carried them in his hand and, though wrapped in a paper, they made him feel quite ill. At another time he had all the symptoms of mushroom poisoning from smelling of two fine specimens sent him by a friend.

The beautiful orange mushroom is also quite common. It is found mostly in open woods or groves where the soil is poor. The bright coloring of the cap in contrast with the white stem and gills makes it a very showy plant. It is sometimes called the fly mushroom. There is something about it that attracts flies, but to taste its juices means death to them. Dead flies are often found on the ground under it. It has been used for many centuries in making fly-poisons.

From earliest times the poisonous character of this plant has been well known. The Roman emperor, Claudius, was given poisonous mushrooms to eat and died from the effects.

Notwithstanding its poisonous character this mushroom is eaten by people of Russia and Siberia. It is thought that in those places there is something about the plant that prevents it from being so poisonous as it is here. Instead of killing the people, it intoxicates them.

Another poisonous Amanita is seen in the brown mushroom. The gills are white, as in other members of the family, but the stem is light brown. 


\section{TREE MUSHROOMS}

The last of these four mushrooms has been known for a long time. It is not poisonous. The Greeks and Romans were very fond of it. They called it food of the gods. Cæsar's mushroom and the imperial mushroom are other names for it.

\section{TREE MUSHROOMS}

Among the fungi growing on decaying stumps and trees is a form known as the oyster mushroom. It was

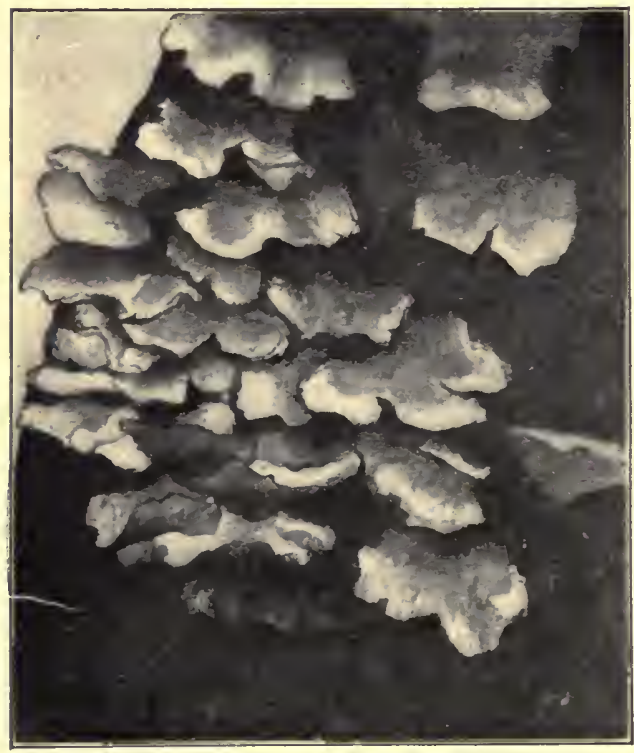

The Oyster Mushroom. given this name because its shape is much like that of the oyster shell. These mush rooms $\mathrm{grow}$ in clusters and sometimes overlap each other. They are often irregular in shape because of this crowding. A single mushroom may be five or six inches broad. They grow sideways from the tree 
and have little or no stem. If there is a stem, it is fastened to the side of the cap. The upper surface of the fungus is light brown or buff. The gills are a dirty white and they bear white spores.

These plants are found from June to November. They are more abundant when the weather is wet. For a long time they have been known to be good to eat, but the flesh is rather tough.

Another fungus which grows on trees is the elm mushroom. It is called by this name because it is found mostly upon the elm tree. Sometimes there is a single plant; again a dense mass is seen covering several feet of the trunk or branches. The stem of the plant is generally longer than that of the oyster mushroom, and it is attached to the cap between the center and the edge. The upper surface is yellow or

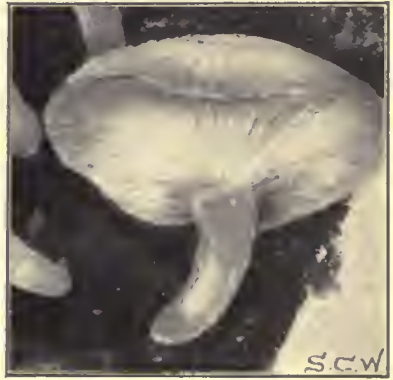

Elm Iushroom. buff. When young it is smooth, but it becomes broken and spotted with age. The flesh and spores are white.

On account of its peculiar flavor this fungus is sometimes called the fish mushroom. It looks somewhat like fish, too, when cooked. Some people have called it the tree fish.

There is a third member of the family of tree fungi 83 


\section{MUSHROOMS}

that is quite different from those that we have been reading about. It is not as common as the oyster and elm mushrooms. It is of a dark-red color, and is very soft and juicy. One writer in describing it says that it

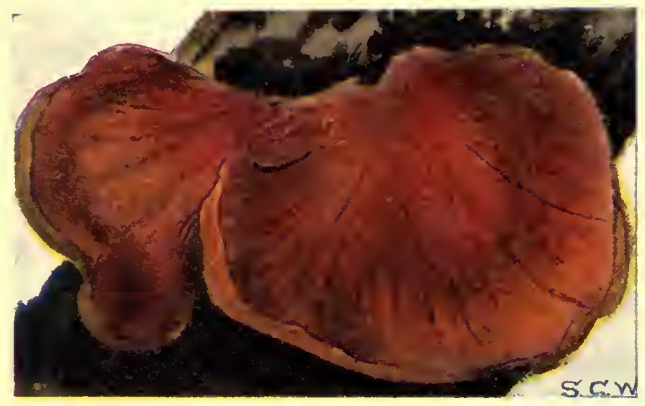

The Beefsteak Mushroom. looks like a big red tongue sticking out from the tree trunk.

This fungus is called the beefsteak mushroom. Of course we can tell why it received this name. But it has other names, too. Sometimes it is spoken of as the yegetable beefsteak. Why, do you think, was it given this name? It is often called the oak or chestnut tongue. This is because it grows mostly on oak or chestnut trees. Here it may be found in wet weather from June to September.

The beefsteak mushroom usually has a short stem which spreads out into the broad and thick cap. When young the upper side of the cap is velvety and of a beautiful peach color. As it grows older, it loses its velvety look and becomes a deep red with darker red lines extending toward the edge of the cap, as you may see in the picture of it. 


\section{TREE MUSHROOMS}

These are only a few of the many fungi that grow out like brackets from dead or living trees, and from the stumps that stand as monuments to mark the spots where trees once grew. Some of these mushrooms are

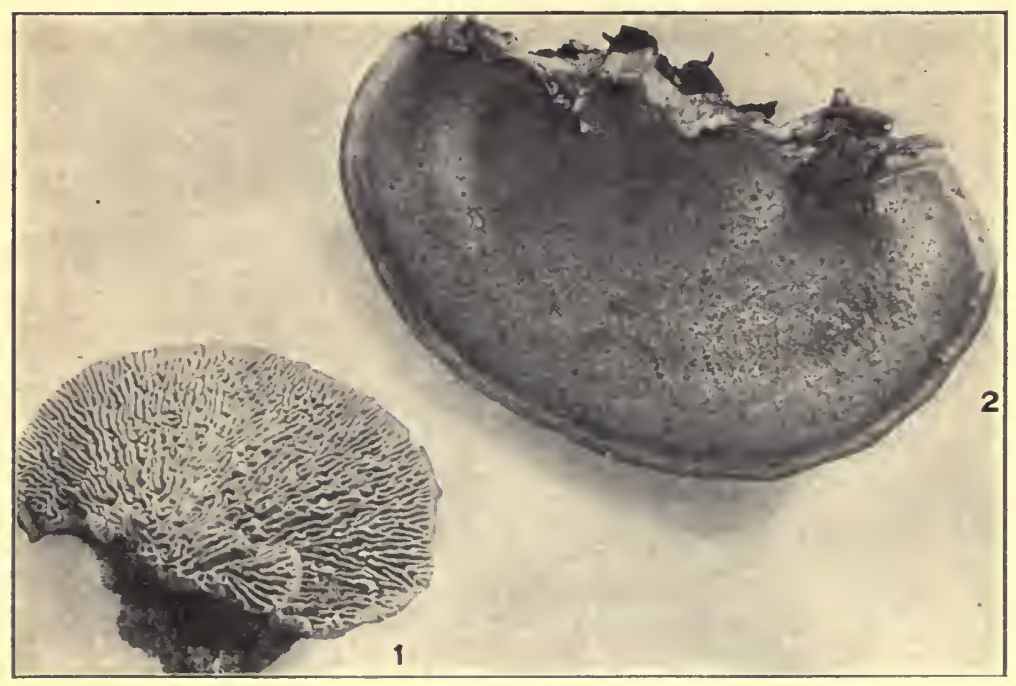

Under Side of Bracket Fungi.

1. Showing the Gills.

2. Showing Spores, or Tubes.

very bright-colored, while others are so like that upon which they grow and feed that they can scarcely be seen a little distance away. 


\section{PUFFBALLS}

Childrex like puffballs. It is such fun to squeeze them between the fingers and watch the "smoke" come out. This cannot be done until the puffball is old and dry. When young this fungus is grayish or brownish on the outside and white within. A few varieties are dark inside. The firm, soft flesh of the inside is covered with a skin or rind consisting of two layers. The outer one is generally somewhat rough. The inner coat is thin and papery.

Let us see how these puffballs grow. The mycelium forms a network of white threads. Then little buttons are seen coming out on these white threads. Like other mushrooms they grow larger and larger, but there is no stem. Neither do they spread open and show gills or tubes. They remain wrapped in their light-colored coats.

Where do you think that the spores grow? If you were to look at the inside of a puffball with a microscope or magnifying glass, you would find it full of little cells. Within these are dustlike spores. Often there are elastic threads among the spores. These help to push out the spores when they are fully ripe.

When a puffball begins to grow larger, the inside becomes so filled with moisture that water may be squeezed out of it. The color changes from white to 86 


\section{PUFFBALLS}

yellow, and then to a greenish brown. Later, the wet mass becomes dry and powdery. The outside grows darker as the puffball dries. The spores are now ripe and the skin opens by a small hole so that they can escape. Such puffballs are often seen lying on the ground or clinging to old stumps or dead trunks of trees. When the boys and girls pick them up and squeeze them to see the "smoke," they are really helping them to scatter their spores so they may grow into new plants.

There are many kinds of puffball, but we will talk of but

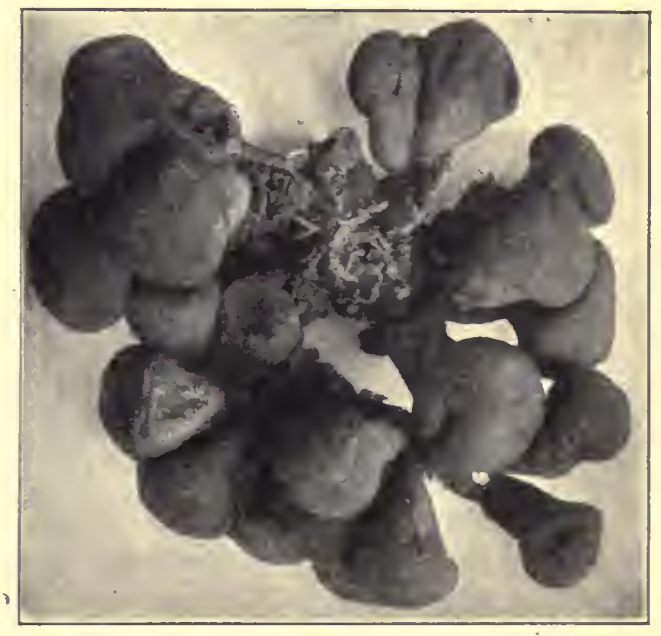

Pear-Shaped Puffballs. two of them.

The first and largest is the giant puffball. It is from eight to fifteen inches across. The skin is thin and nearly smooth-whitish at first, but yellowish as it grows old. It is found in grassy places during August and September.

Before matches were made, the dry, spongy inside 


\section{MUSHROOMS}

of this puffball was used as tinder to catch the sparks which flew from the flint when it was struck for fire. The spore dust of this fungus has sometimes been used to stop the flow of blood from a wound.

Another variety that is quite common is the pearshaped puffball. These are found everywhere in the world. They grow on old timber or on the ground in groups. Those that you see in the picture were growing on the ground along a country roadside. The group from which they were taken was about two feet in extent. When they were picked the inside was white and firm. Now they have turned dark. The spores are ripe and are of a greenish brown. Some of them have the hole in the skin, and a little pressure will scatter the spores. "

All of the puffballs that have white flesh are good to eat, as long as the flesh continues white. If, when cut, the knife leaves a stain of yellow, the mushroom is too old to cook. Puffballs that are dark inside when young are not thought to be fit for food.

\section{THE CORAI FUNGI}

IF you have ever seen coral, you can guess why these are called coral fungi. There are a great many beautiful plants among them. All of them stand up straight, or nearly so. Some are single, others are 88 


\section{THE CORAL FUNGI}

clustered; some are joined by their bases, and others are very much branched. Among the different colors seen are white, yellow, violet, red, and brown. Some have red at the tips only.

One of the handsomest of them is the yellow one seen at the beginning of this chapter. It grows from four to six inches high. There is a stout stem which goes down deep into the ground. From this grow the branches, at first stout ones, and then slender and longer ones. These end in many tips. When young the branches are red, pink, or orange. As the plant grows older

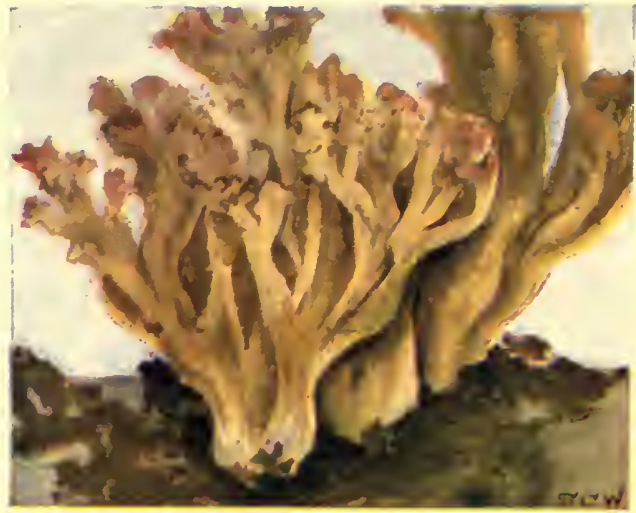

The Elegant Clavaria. the color fades to a light yellowish or creamy buff. The spores are on the outside and probably give the fungus its color. The whole plant is very brittle. Therefore, it has to be handled with great care.

This plant grows in the woods among the dead leaves and decayed logs. The dimness of the forest is lighted up by its bright-yellow branches. You see 


\section{MUSHROOMS}

Mother Nature is fond of color and gives us touches of it everywhere.

None of the coral fungi, or clavarias, is poisonous, but some of them are so bitter or tough as to be unfit

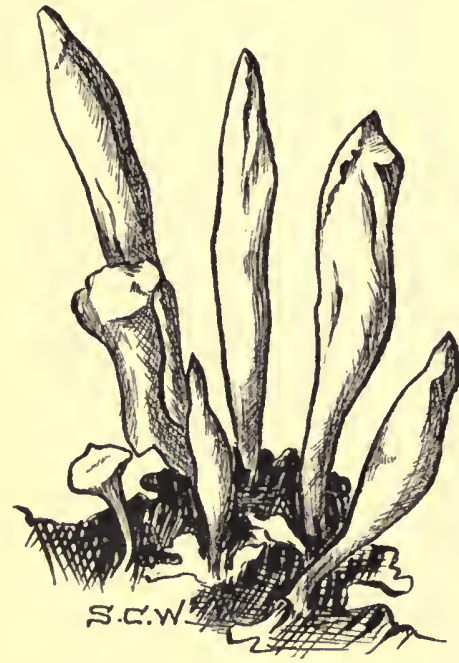

Little Tongue Clavaria. for food. The flesh of some is very tender. They often grow in such large and dense clusters as to make one think of huge cauliflowers. The time to get them is in the fall.

There is another form that is sometimes called the true coral fungus. Its color is white. In shape it is very much like the yellow one seen in the picture. It smells like the common meadow mushroom, and has a pleasant taste. This fungus is much used in Germany, Italy, and Switzerland, where it is dried for winter use.

Here is a picture of an odd-looking plant. It is called the Little Tongue Clavaria. When young it is yellow, but as it grows older it turns to a light, pinkish brown. 


\section{MOSSES}

IT seems as if nature filled up all her vacant spaces with tiny flowerless plants. Where nothing else can grow, these find a home and make the earth more beautiful. Of all these plants the mosses are the loveliest, but they are not showy. Did you ever notice their delicate coloring, their variety of form, and their fine, lacelike leaves? The careless passer-by sees nothing of their real beauty. But Ruskin, who loved them, said: "No words that I know of will say what these mosses are. None are delicate enough, none perfect enough, none rich enough."

Ferns and flowering plants require soil for their roots, but mosses thrive where there is but little. Sone grow upon the ground; but many like best the rocks or trunks of trees. Others grow on decayed wood, stumps, or fallen trees. Ponds and small streams, too, have their share, for many of them are water lovers. Indeed, mosses are hardly absent from any place except salt water.

In the arctic regions where there is little plant life, they carpet the ground, giving a beautiful greenness to the mountains and valleys. On the hot plains of Africa 


\section{MOSSES}

and around hot springs in different parts of the world, they flourish and continue green under a heat that is fatal to all other vegetation except lichens.

They love best the moist places, but do not refuse to grow where the soil is dry. Tufts of them may be seen here and there on the sandy desert.

We find them on the mountain tops amid howling winds and driving storms, as well as in the calm and silent woods where scarcely a breath of wind can stir their leaves.

There is, in fact, no spot on earth so dry or wet, so cold or hot, so stormy or so quiet, that these tiny flowerless plants do not find a dwelling place. They are, however, most abundant in the temperate zone. Here, too, they have their favorite haunts. At the foot of the mountains, in rocky dells, with streamlets murmuring through them, and the trees making a dim twilight, they form their soft, green carpets.

In mosses, as elsewhere in nature, uses and beauties mingle together. To them is given the task of preparing the way for. higher forms of plant life. Before we can have the wheat for our daily bread, or grass for our cattle, or cotton and linen for cloth, mosses and lichens prepare the soil for these useful plants.

Mosses protect the roots of trees and plants from heat and cold. They make a home for insects. In mountainous regions the thick mats of moss help to soak up the rain and prevent floods from sudden storms. 


\section{MOSSES}

By holding this moisture until needed they aid in supplying the stream during dry weather.

"Fringeless or fringed, and fringed again, No single leaflet formed in vain; What wealth of heavenly wisdom lies Within one moss cup's mysteries! And few may know what silvery net

Down in its mimic depths is set To catch the rarest dews that fall Upon the dry and barren wall. Voices from the silent sod, Speaking of the perfect God."

Man has found many uses for mosses. We shall find that these plants add much to our comfort and happiness.

Some mosses ripen their spores after a few months and die. Others live from year to year. Among a few kinds, the lower part dies and the tips keep on growing until there is a mass that is of great thickness.

These plants may be studied at all times of the year. When the flowers and most of the ferns are gone these humble companions still cheer us with their bright, fresh looks. 


\section{MOSSES}

\section{THE PARTS OF THE MOSS PLANT}

WE often hear people speak of moss as if there were but one kind. Perhaps you will be surprised to learn that over ten thousand kinds are already known.

Some of them are slender and hairlike; others look like small trees; a number of them resemble feathers. All of them have roots, stems, and leaves, like other plants.

The roots are very delicate, yet they take as firm a hold of the soil, in proportion to their size, as many trees. They consist of small, threadlike fibers, or long, creeping, underground stems, like the ferns except that they are smaller. In most cases these serve only to attach the plant to its growing place, for every part of the moss takes in its own share of nourishment.

Many of the mosses have long stems that branch and branch again. Others have scarcely any stem. They seem to send up from the root a mere tuft of leaves. The stems are solid and are made up of many cells. They have no woody fibers running through them as the ferns and flowering plants have, so they cannot stand up erect. These stems are of a reddish color, or of green or brown. If you look at a moss stem carefully you will find that the leaves grow around it on all sides.

The leaves of mosses are the part that we notice first. If you examine them with a microscope you will see 94 


\section{THE PARTS OF THE MOSS PLANT}

that some have notched edges, while others are plain; some are long like pine needles, others are oval or round; some have a nerve or vein which runs through the center.

During the winter and spring the mosses begin their

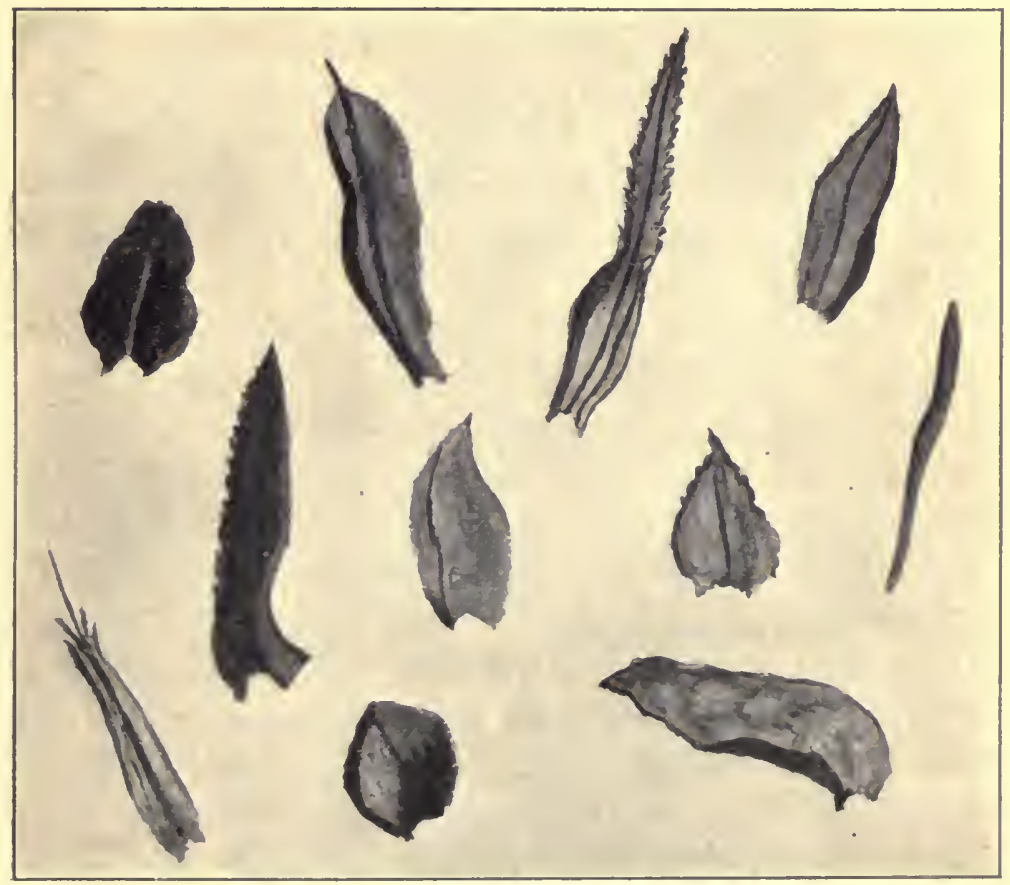

Different Shapes of Moss Leaves (Much Enlarged).

work of spore-bearing. A large number of hairlike stalks rise out of the bed of green leaves. They are from one to three inches tall. When young their color 


\section{MOSSES}

is pink, but later they turn to red, orange, or brown. They make the moss look like a green pincushion well filled with pins.

After a time small sacs appear at the top of these hairlike stalks. At first they are but little thicker than the stalk. Soon they grow larger and take different shapes. Some are pear-shaped, and some are nearly round; others urn-shaped; or they may be long and slim. A few are like cubes or cylinders. One form looks much like a closed parasol; another resembles a small bug. These are the capsules that contain the spores.

Until nearly ripe many of the capsules are covered with little caps having high peaks and long laps. These protect them from the sunshine and rain until they are fully grown. Then the hood or cap is torn from its support and carried to the top of the capsule, where it stays until the spores are nearly ripe. At length it falls off altogether. Then we find that under it there is a little lid which covers the mouth of the capsule.

When the lid comes off there is found around the mouth of the capsule a fringe of single or double rows of teeth. These open in sunshine and close in rainy weather. If you were to examine the inside of the capsule with a microscope, you would find that the spores, inclosed in little bags or spore cases, grow around a column or pillar in the center.

When the spores are ripe, it is a curious sight to see 96 


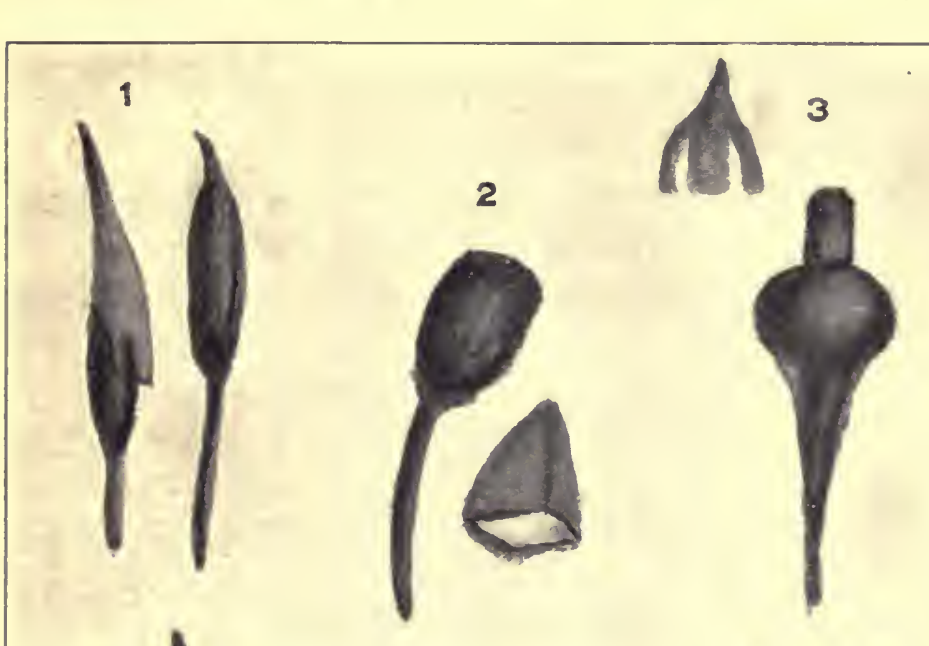

$$
\begin{aligned}
& \text { 1 } 19
\end{aligned}
$$




\section{MOSSES}

like plant appears much like the prothallium of the fern. Soon buds of young moss plants appear. On these the plants grow and produce spores which in their turn fall to the ground and grow into new plants.

Roots will grow from any part of a moss plant that is kept dark and moist. Often roots and new plants will grow from a leaf that is broken off. Mosses thus spread very rapidly.

\section{TREE MOSSES}

Do you remember that we said there were mosses that looked like small trees? The picture shows you some of these. See what long roots they have. Do they not look like the slender creeping rootstocks of some ferns? The little treelike plants come up from this underground stem in the same way that fern fronds spring up from their rootstocks. Because this moss is so much like little trees it is called tree moss.

Notice how the stems bearing the capsules come out from among the green leaves at the side of the stem. There are quite a number of our mosses whose capsules grow in this way. The tree mosses are among the largest of these. The capsules nearly always stand up straight at the ends of their long stems. When young the capsules are green, but as the spores ripen they turn brown. The beak at the top has a long point. When 98 


\section{PEAT MOSS}

the spores are fully ripe, this beak drops off and allows the spores to escape.

The tree mosses are common in wet woods. They are also found in moist, grassy places, but they do not often bear fruit when growing there. Even in the woods their capsules are not very plenty. Some years we have looked in vain for plants with fruit. Several patches of the moss were found on which there were many capsules.

There are several kinds of tree mosses. Most of them stand up straight, like those in the picture. One kind, however, creeps on the ground. It rarely looks like a tree. This form is very plenty in the swamps of Long Island.

\section{PEAT MOSS}

Ix some countries peat is almost the only fuel of the poorer people. In the United States there is an abundant supply of it. But we have so much fuel that is cheaper and better that little peat is used.

Peat is formed of peat moss which grows in and near water in swamps. The plants grow at the top and die below. Sticks, leaves, and other substances are washed in among the decaying stems. The whole mass, being full of water, decays slowly, packs closely, and becomes a hard, dark-brown or black substance known as peat.

The life of this moss seems to be endless. The 99 


\section{MOSSES}

mosses which we see growing in a bog now are the tips of plants which began life perhaps thousands of years ago. These have formed great beds of peat which may be

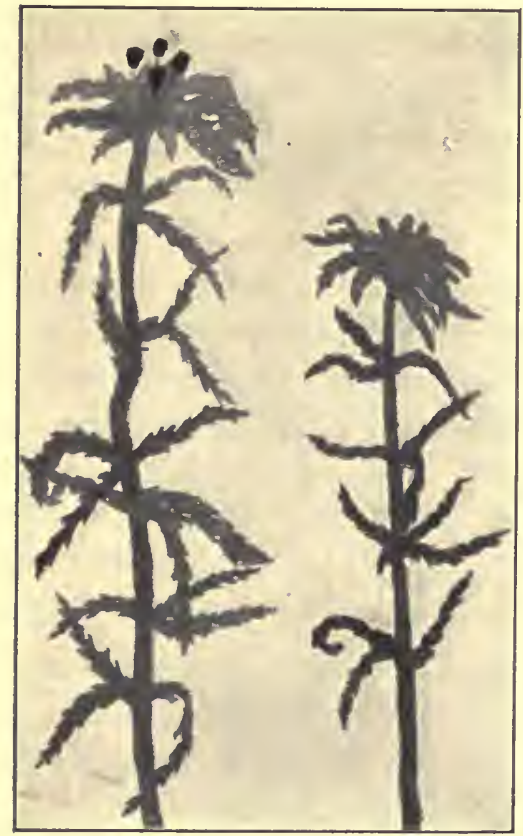

Peat Moss. from fifteen to twenty feet thick.

The peat mosses are among our largest moss plants. They are usually pale green, but may be a dirty white, a dark red, a pale pink, or a yellow. Those seen in the picture were found among the White Mountains in New Hampshire, where there was an abundance of red plants. Both leaves and stems suck up the water like a sponge, so that the whole mass is full of moisture.

There is little or no root. On the young plants only are root hairs found. The plants seem to float in an upright position, unattached. As they grow closely packed together they help each other to stand erect. There are many branches. The shorter ones at the top are often much crowded. 


\section{PEAT MOSS}

The leaves have no midrib, but grow around the stem in a spiral manner. They are fastened to it by a broad base and taper to a point. You can see this in the picture.

The stalks on which the capsules are borne are not like those of other mosses. See how short and thick they are. The branches at the top extend upward to form them. A capsule is shaped somewhat like a vase. When ripe it opens by a circular lid.

Peat mosses are of more value than any others. If you were to visit Ireland you would find great tracts of land covered with peat bogs. Vast amounts of fuel are obtained from these. In the Highlands of Scotland peat forms the largest part of the fuel of the inhabitants.

This is also the principal moss north of the arctic circle. Great quantities of it grow in Lapland. Here it is used for beds. The Laplanders also use it for their little babies instead of clothes, packing their cradles firmly with it. In seasons of scarcity they make a wretched kind of bread out of this plant. Florists everywhere use this moss for packing flowers, because it holds moisture for so long a time.

We owe our coal to the remains of ferns, and our peat to the mosses - two of the simplest of our plants providing fuel in large quantities. 


\section{FERN $\cdot$ MOSSES}

Everybody admires fern mosses. Their branches grow very regularly, just as the parts of the fern frond

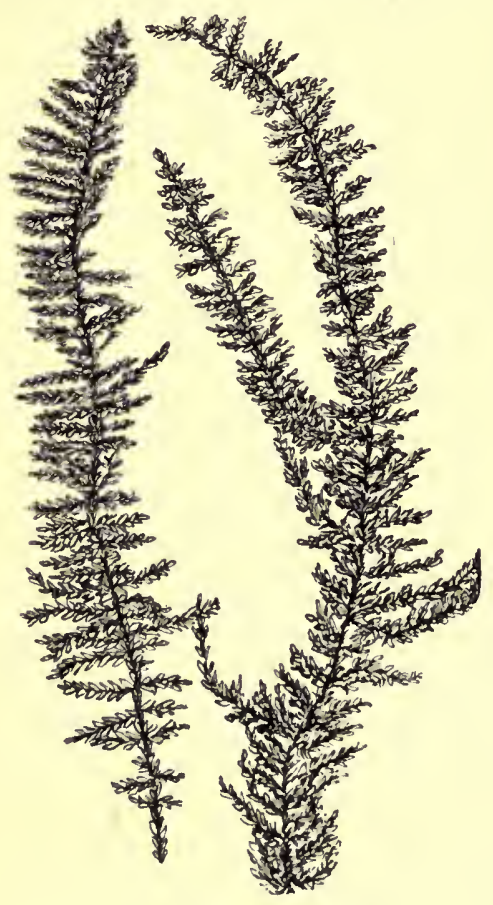

Common Fern Moss.

do. They often send out branchlets that are also very regular.

The common fern moss grows in damp, shady places, spreading over stones, decayed logs, and waste places of the earth. It reminds us of Ruskin's words when he says, "Creation full of pity, covering with strange and tender honor the scarred disgrace of ruin-laying quiet finger on the trembling stones, to teach them rest."

Another common fern moss is found growing on poor soil in dry places. This is called the wiry fern moss. It is rather stiff and grows in thick mats.

The mountain fern moss is a very beautiful kind. It is larger than the others. One thing about its growth 102 


\title{
HAIR-CAP MOSSES
}

is peculiar: Every year each of the main shoots of the year before sends out a single fernlike branch from the middle, instead of branching out from the side of the shoot, as most mosses do.

This plant grows in great quantities in cool, moist mountain woods, and on stones and old logs. If you study the picture of this moss you will probably know the plant when you see it in the wood.

There are not many capsules in proportion to the number of plants. Sometimes, however, a

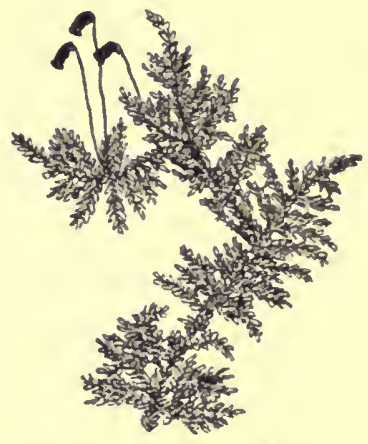

Mountain Fern Moss. patch of this moss may have an abundance of fruit. All fern mosses are easily known from their fernlike forms. They are found

\author{
"Springing in valleys green and low, \\ And on the mountain high, \\ And in the silent wilderness \\ Where no man passes by."
}

\section{HAIR-CAP MOSSES}

The hair-caps are our largest common mosses. Some grow in old fields and meadows, or along the roadside, while others seem to want the shade and moisture 


\section{MOSSES}

of the woods. Farmers do not like the common haircap because it spreads rapidly and takes the place of grass in their meadows.

Near our home was an old field where this moss grew in many places. We have often seen the children

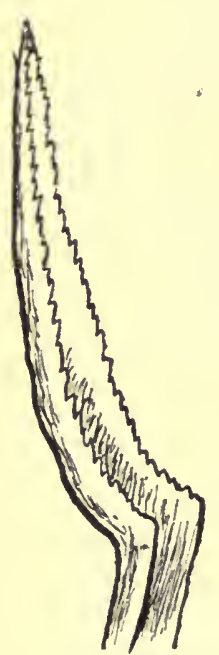

Leaf of Hair-

Cap Moss. gather it in handfuls and, seating themselves upon the ground, begin to make "rings" of it. They did this by bending the stems and fastening them together at the end of the capsules. These were then placed upon their fingers and worn home in triumph.

The-leaves of the common hair-cap are very thick and strong. Notice their thin, clasping base and notched edges. Their appearance is very different when dry from what it is when wet. They spread out when moist and are fresh and green, but a lack of moisture causes the leaves to fold up against the stem. This is to prevent rapid evaporation. When left dry for some time the plant turns brown. If placed in water for a little while, it will regain freshness and color. We have some mosses two or three years old that can be made nearly as beautiful as they were at first by letting them remain in water for a short time.

The reddish-brown stems are from two to eight inches long. At the end of each is a capsule of the same 


\section{HYPNUM MOSSES}

color. This capsule is almost like a cube in shape and has a lid at the top of it. The lid has a very short beak. The grayish-brown hairy cap that entirely covers the capsule gives the moss its name.

The capsule ripens in June or early July. Then the cap falls off, the lid drops, and the spores escape.

If you were to pick some of the hair-cap moss when ripe and pull off the cap, you would find under it the beaked capsule. With a pin or a penknife remove the lid and let the spores fall upon a piece of dark-colored paper. They are quite a bright yellow and may be easily seen with a lens. Without the lens they look like a mass of fine yellow powder.

The common hair-cap moss is found in all parts of North America, in Europe, and in Asia. In England it is sometimes used for brooms. The Laplanders use it to stuff pillows and beds.

\section{HYPNUM MOSSES}

MANY of our common mosses belong to the Hypnum family. Its members usually grow in dense mats on the ground, stones, bark of trees, and rotten wood. The most of them are slender and lie nearly flat. Some are creeping, with branches rising up from the mass of green. There are many kinds of hypnums, but we can study only a few of the common ones.

When you find a bright yellow-green moss growing 105 


\section{MOSSES}

in dense cushions you may make up your mind that you have some kind of a hypnum. Examine it closely with a magnifying glass. If it is quite large and has bright-red stems showing through the leaves, it is a

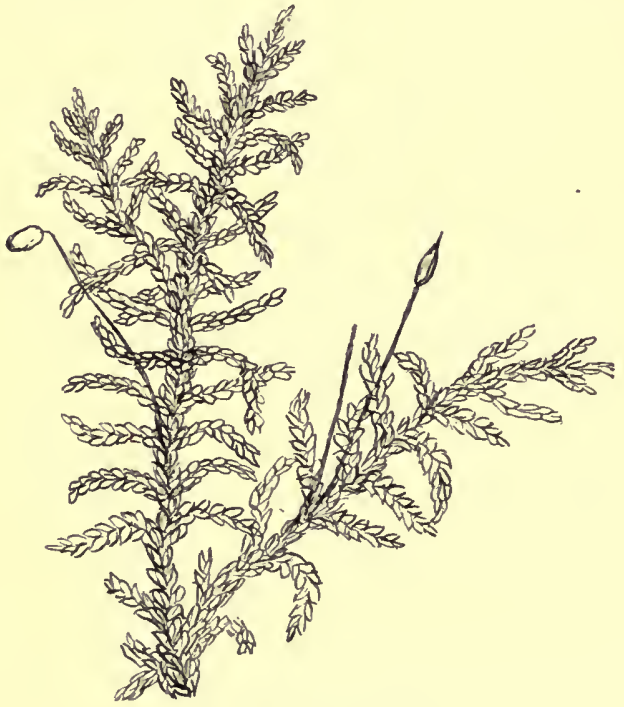

Schreber's Hypnum. Schreber's Hypnum. This is a beautiful moss which grows in abundance in pastures and open woods. We have seen almost the entire surface of decaying logs covered with its dense green cushions. If you gather some of this, it will keep for a long time. When placed in water the fresh, green look will return, and the red of the stems will be quite bright again.

The stems of this moss are often from four to six inches long and nearly erect. They crowd very close together. The capsules ripen in the fall. One would think that such large plants would have many capsules, but they do not. 


\section{HYPNUM MOSSES}

A hypnum that is easily recognized is the plume moss. Doesn't it look like a feather? This is common on decayed wood and stumps, in cool, moist woods in New England and New York. It is most beautiful in the mountain forest, where it covers the decaying trunks of fallen trees with its delicate, light-green plumes.

The pinnate hypnum is common in lowlands. It grows almost entirely on rotten wood, in moist, shady places. It is a darker green than the plume moss and lies flat upon the logs in close, dense mats. The branching does

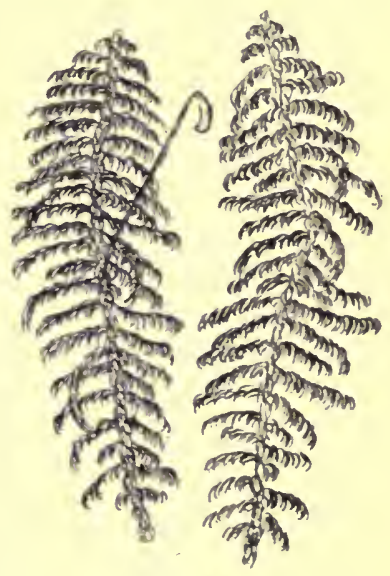

Plume Moss. not extend to the tips, as in the plume moss. Notice this in the pictures of the two mosses. It is one of the

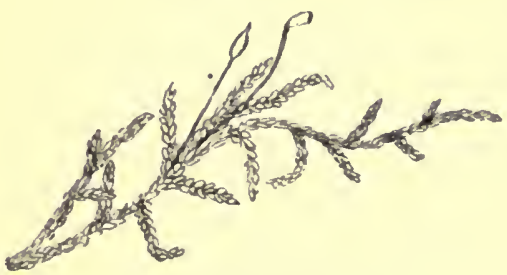

Pinnate Hypnum. ways by which you can know the pinnate hypnum. These plants have many capsules. They ripen in winter, but remain in good condition for a long time.

Another common hypnum is the shaggy moss. It grows on shaded banks that are neither very wet nor extremely dry. 'The name 


\section{MOSSES}

"shaggy" describes the plant well. It has a ragged look. The branches are irregular and the leaves stand out straight from the stem. A picture of this does not

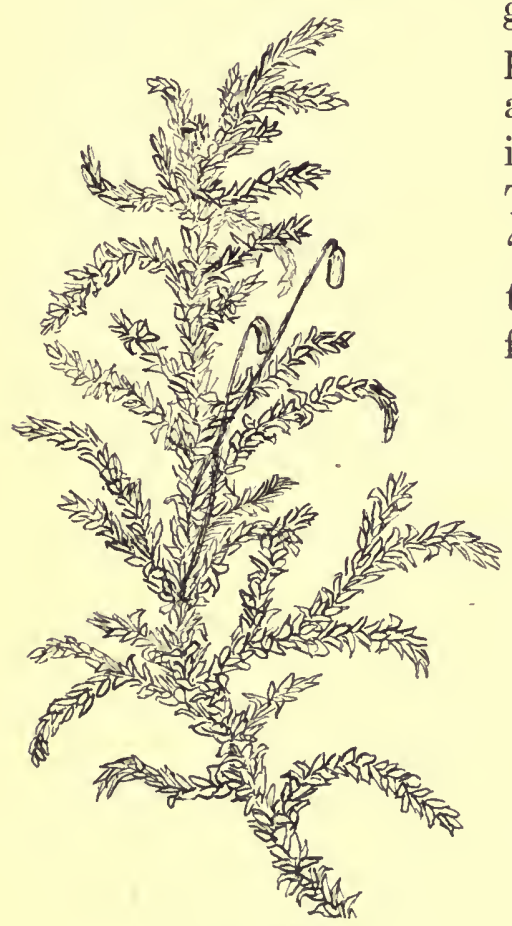

Shaggy Moss. give a very good idea of the plant. It should be seen, and when once recognized it is not easily forgotten. The stems are elastic, or "springy." For this reason they are sometimes used for packing china and glass.

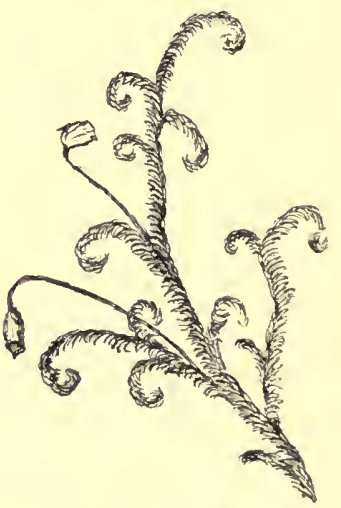

Hooked Moss.

Hooked mosses also belong to the Hypnum family. They may be easily known because the leaves at the ends of the branches curve so as to look like little hooks. These mosses grow on rocks, earth, and rotten wood, in 
shaded swamps, and along shores of lakes and edges of streams.

Some of the hypnums grow on stones in the beds of brooks, where they are under water except when it is very low. All but the youngest part of the plant is very dark, almost black.

None of the hypnums that we have described, except the hooked mosses, has a midrib. A magnifying glass will show you that these have.

The members of this family are so much alike that it is not easy to tell them apart. If you learn to know the ones we have been talking about it is enough for the present.

\section{WATER MOSSES}

"Mark ye the ferns that clothe the dripping rocks, The crosier-headed ferns most fresh and rare; And velvet mosses, fostered by the flow

Gain a luxuriance all unknown elsewhere."

In mountain regions there are many small streams which wind their way down to the valleys. Sometimes they make sudden leaps over the rocks, as if in a hurry to get to the end of their journey.

The picture shows you one of these mountain streams just at the place where it is taking a long 


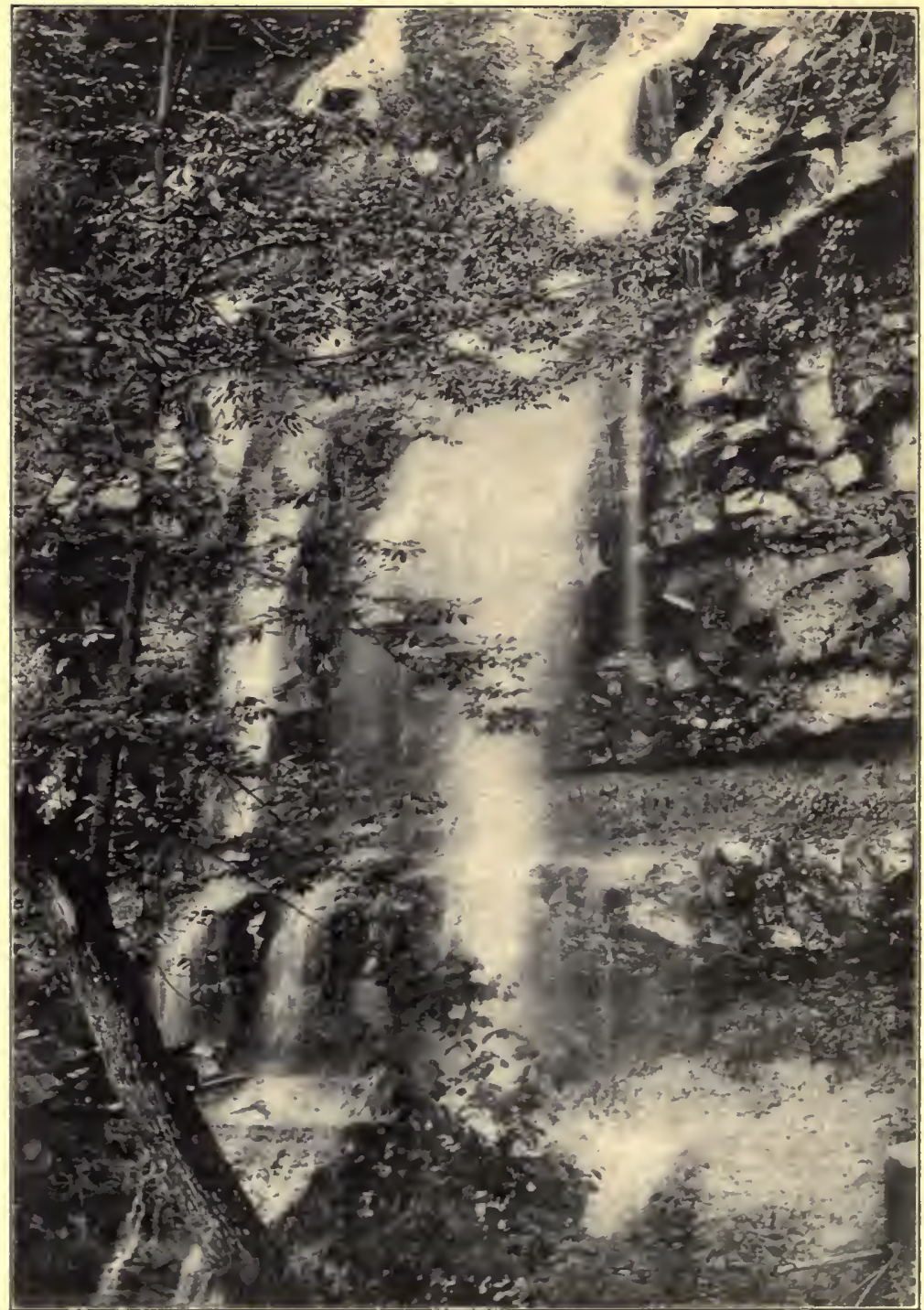

A Mountain Stream at the Point where it Takes a Plunge Downward. 110 


\section{WATER MOSSES}

plunge downward. This stream is among the Catskill Mountains. All along the sides of the rocks, kept moist

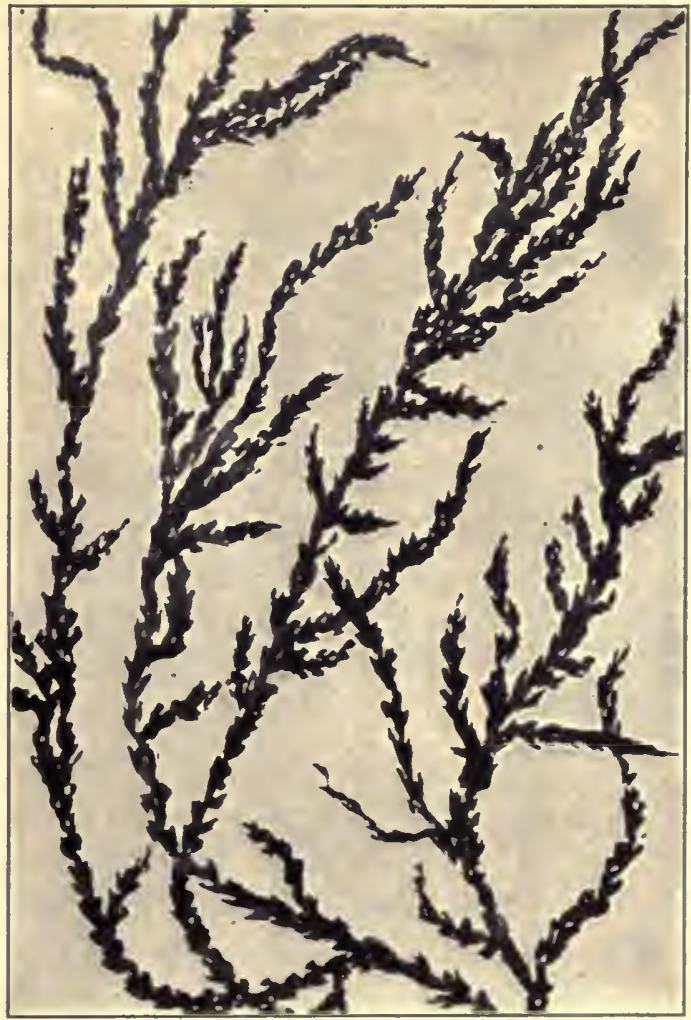

The Giant Water Moss.

by the spray, are many beautiful ferns and mosses. But the mosses that we are going to talk about now do not grow here. 


\section{MOSSES}

In the streams above these falls the water is clear and cool. Here grows the giant water moss. This plant is fond of cool streams where the water flows swiftly. It grows on stones and sticks which lie in the bed of the brook, or on the roots of overhanging trees.

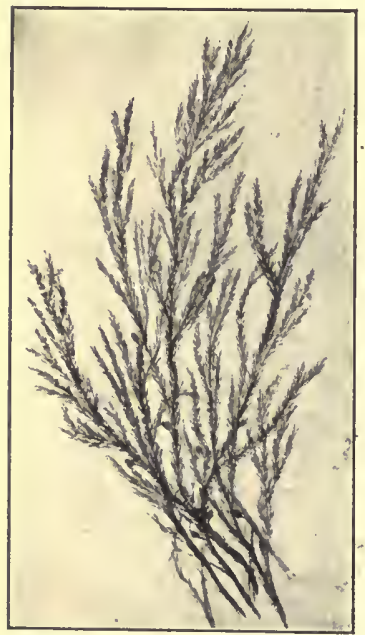

The Common Water Moss.

Has it not beautiful shades of coloring? It looks just like this in the water. The plants are large, the branches being sometimes a foot or more long. This makes it very easy to see. . It has thick three-cornered stems and branches. These spread out in the water and float along with the current. This plant is called the giant water moss because it is the largest of them.

There is one strange thing about this moss. It is very difficult to burn it, even when it is completely dry. Because of this it is used in some parts of Europe for lining chimneys. It prevents the woodwork about the chimney from taking fire.

You see here another kind of water moss. This is much more common than the first. It, too, has very beautiful coloring, and a soft, silky look. Sometimes it is called the delicate water moss. This moss grows in 


\section{OTHER COMMON MOSSES}

the same locality as the giant water moss. Both of them are found in streams among the White Mountains in New Hampshire.

There are many other kinds of water mosses, but these are among the most beautiful.

Sometimes pieces of moss are broken off and carried along by the current. Perhaps they will fasten themselves to some object farther down the stream. There is no knowing where will be their next home. They themselves do not know.

"Soft green moss that floats along,

Down the bright stream

With current so strong,

Tell us, oh, tell us,

Where now do you go?"

Soft is the answer,

"I do not yet know."

\section{OTHER COMMON MOSSES}

WE will now glance at a few more of the common mosses. One is an odd little plant called the Web'-e-ra. Its leaves are quite small and form a broad mat of dark green. Nestled in this green mass are the capsules, that look like little bugs. They have very short stems. 


\section{MOSSES}

The Webera grows on moist banks where there are few tall plants. A lichen is almost always found with it.

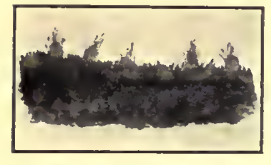

Webera Moss.

Another common moss is the Georgia, named for an English king. It grows on rotten stumps, or on the banks of brooks. On the western end of Long Island it is found in abundance. This is a small moss, but it may be easily known by its capsules. At the end of each there are four long teeth. These may be seen with a lens, and if one has good eyes it is not difficult to see them without a glass. It is the only common moss plant with this number of teeth.

Some very common mosses in the woods are the $\mathrm{Di}^{\prime}-\mathrm{cra}^{\prime}$ nums. Of these there are a number of kinds. They are generally a bright yellow green and grow in wide, thick tufts or mats.

The broom moss belongs to the Dicranum family. Its likeness to a tiny broom gives it its name. All the leaves turn to-

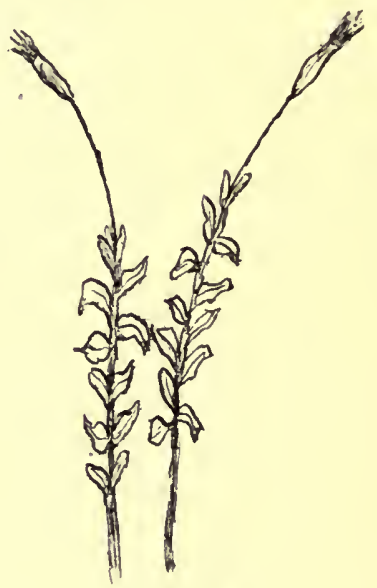

Georgia Moss. ward one side, but they are not crisp when dry, as some of the Dicranums are. It has single curved capsules. These are long and slender. This plant is often used by florists to form banks of green in their show windows. 


\section{OTHER COMMON MOSSES}

The wavy Dicranum is the largest and most beautiful of all this family. It grows on the ground and on rocks. Its leaves are very wavy, and have a beautiful silky gloss. Like the broom moss they look as if the wind had blown them all in one direction. The curved capsules grow in clusters instead of singly, as the broom mosses do.
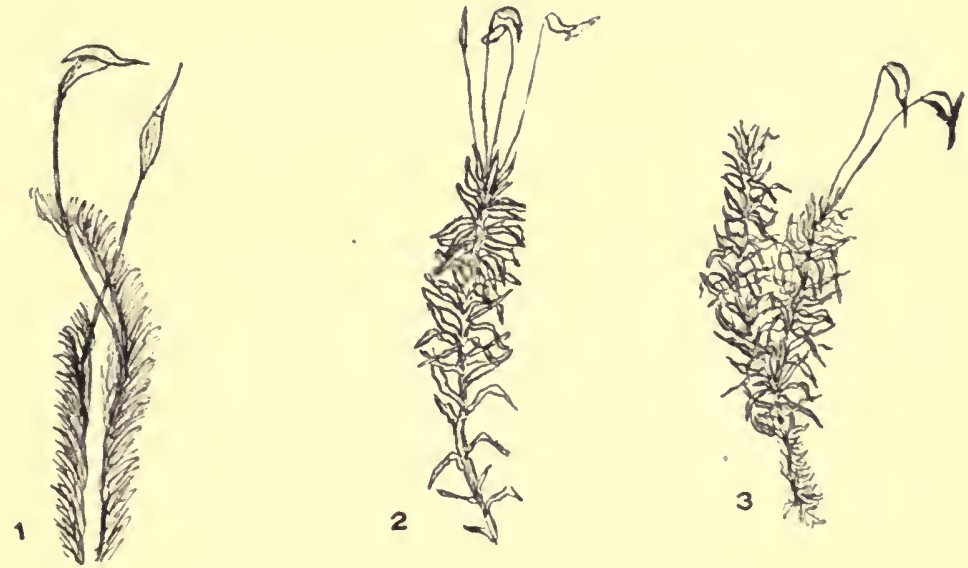

Dicranums.

1, Broom Moss; 2, Wavy Dicranum; 3, Drummond's Dicranum.

Everybody has seen the white moss. It grows in tufts looking like great pincushions. It is of a light grayish-green or whitish color. There are few capsules, but these are not needed to tell us the kind. The color and manner of growth show this. It looks much like the peat mosses, and the cushions take up and hold water in the same spongelike way. 


\section{MOSSES}

A plant known as the cord moss is found everywhere. When the spores are fully ripened the moss may be eas-

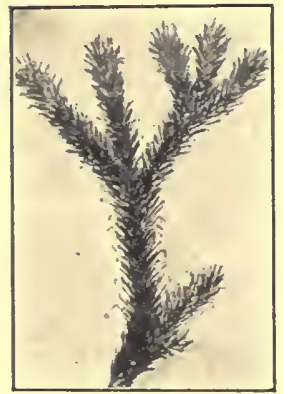

White Moss. ily recognized, because the capsule, with its mouth on one side, has such a strange look. Before it is ripe the capsule stands up erect. Then you may not know it. The spores ripen early in June.

By the roadside and in the fields you will find a moss that looks like this one. It is called the urn moss because of the shape of its capsules. Sometimes it is seen on the earth at the florist's. By the side of the paths in the parks of Greater New York it grows in quantities. You can get it in the best condition in the month of May. This moss is a'near relation to the cord moss, though it looks very unlike it in most ways.

"The tiny moss, whose silken verdure clothes

The time-worn rock, and whose bright capsules rise

Like fairy urns, on stalks of golden sheen."

Here is a Giant Bryum. Don't you think that it looks a little like

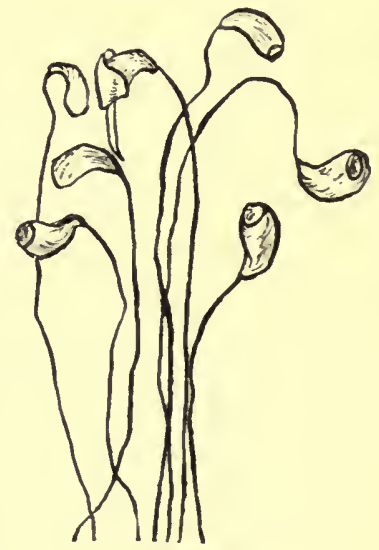

Cord Moss. 


\section{OTHER COMMON MOSSES}

a small tree moss? There is an underground stem. The stems spring from this. See how naked they look until the top is reached. Here the leaves form a rosette from the center of which grows the cluster of capsules. This plant is quite common, and forms large

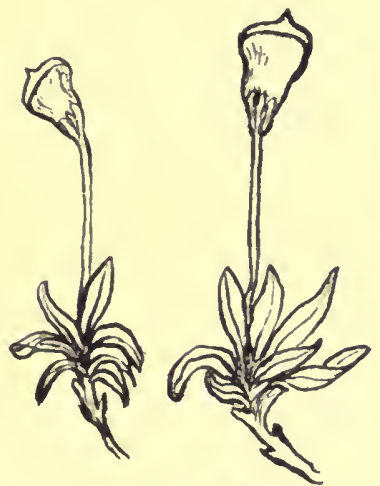

The Urn Mloss.

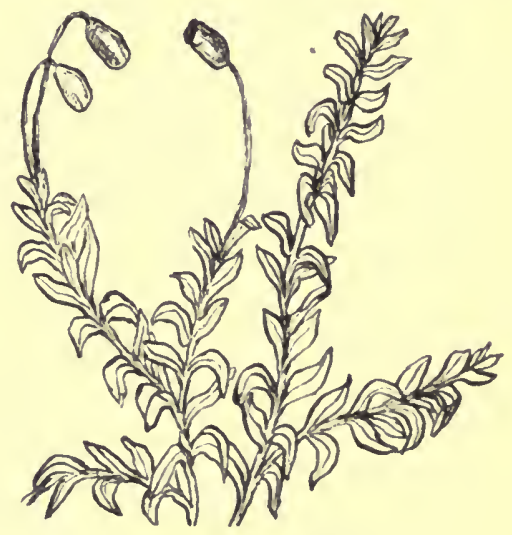

Giant Bryum Moss.

mats on rocks or old rotten logs, or at the foot of trees where the soil is rich.

Many of our mosses are like some twin boys whom we once knew. They were so much alike that few persons could tell one from the other. One day a friend said to one of them, "I don't see how you two boys can tell yourselves apart." He replied very quickly, "Why, when I see Johnny coming then I know I'm Jimmy." When we know what a moss is not, it sometimes helps us to find out what it is. 


\section{Mosses}

Do not be discouraged if, after studying about these plants, you do not know the names of all that you see. There are people who have studied them for years who even now find many of them that they are not sure about.

When you find a new moss notice how and where it grows; study the size, form, and growth of the leaves; find out the shape of the capsule and when it ripens. Then look in a book about mosses and try to find a plant that answers this description. If it is not there look for some one who can tell you about it. If you are in earnest you will find some way of getting what you want. But if you do not get all the names, you will certainly get something, and that is, a great deal of pleasure out of your study. One of our great English writers has said, "He that enlarges his curiosity after the works of nature multiplies the inlets of happiness." Try to find out what he meant. 


\section{LICHENS}

Lichens! What are they? You have probably seen them again and again, but did not know them. Not a rock peeps above the surface of the soil but has these small plants growing upon its top and sides. Some, sprinkled over stones and withered tufts of moss, look like white and yellow flowers; others are like ink stains on the smooth tops of posts and fallen trees; on the bark of trees may be seen many patches of bright green, while

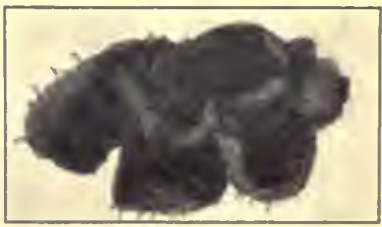

Lichen Attached by Black Fibers on the Under Surface.

long streaming tufts of grayish green hang from the branches.

"Some are reddish, some brown, some gray, and some black,

And they're puckered, edged, buttoned or fringed, front and back;

Some are lying like leather close under your feet, Some waving from trees in the forests you'll meet."

Lichens are composed of two parts. One gives nourishment to the plant, and the other bears the spores. 


\section{LICHENS}

All lichens have a starting point of growth. From this they spread on all sides in the form of a circle. Sometimes the central part is dead while the edge is growing. This part of the plant takes the nourishment from the air.

If you examine the leafy lichens, you will see curious round disks or shields of a different color from the rest of the plant. The spores are within the disks. When

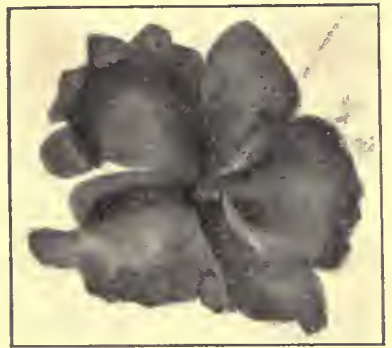

Lichen Attached by a Single Knotlike Root in the Center.

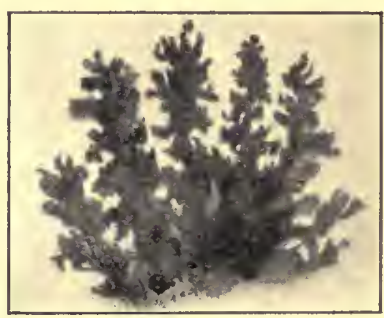

Lichens Attached Closely to the Rock, or the Bark of the Tree.

the entire shield is wet, the part that holds the spores becomes bulged out above and causes a pressure which finally bursts the spore cases. Then the spores are scattered. If you examine the spore cases of some lichens with a magnifying glass you will be surprised at their beauty. They are generally oval in shape. Some are bright red or a golden yellow; others are deep blue, green, olive, or brown.

Many lichens never produce spores in this way. In- 


\section{LICHENS}

stead, the whole surface of the plant is covered with powdery grains which grow into new plants wherever they are carried by the wind.

"Seeds to our eyes invisible can find

On the rude rock the bed that fits their kind."

On some lichens there are spongy tops which look like tiny trees. Then there are the cup mosses that lift up their spore cases above the circles so closely fastened to the rocks. These belong to the bushylichens.

To the crusty lichens belong those plants that look like crusty patches on walls, stones, and trees. One of this group

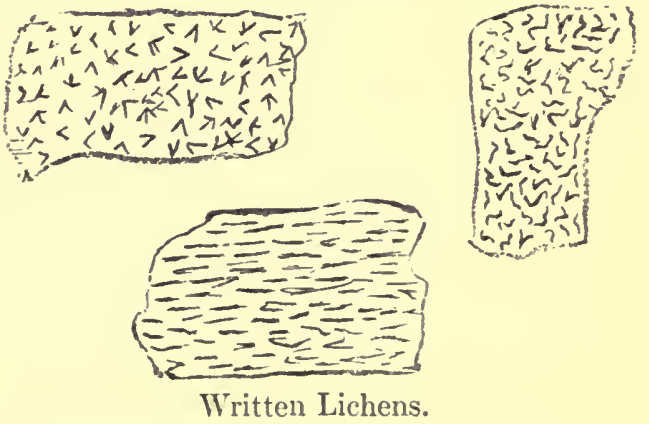
has very strange fruit vessels which look like Arabic and Chinese letters. These lichens grow on the bark of trees and are called written lichens.

Lichens spring up and grow rapidly the first year or two; but after a circular frond is formed, they grow but little for many years. Some of those that we see on trees and rocks must be very old. Every year these plants show renewed life at the approach of winter. 


\section{LICHENS}

Then they seem to delight in moist and stormy weather, and put forth their spores so that we may have new plants.

Lichens grow nearly everywhere on the globe. In the Arctic region they form the largest part of the plant life. Beyond their limits there is no vegetation.

"But here, above, around, below,

On mountain or in glen,

Nor tree, nor shrub, nor plant, nor flower,

Nor aught of vegetative power,

The weary eye may ken.

For all is rocks at random thrown,

Black waves, bare crags, and banks of stone;

As if were here denied

The summer's sun, the spring's sweet dew,

That clothe with many a varied hue

The bleakest mountain side."

In some countries lichens provide food for man and beast. Several kinds are used for dyestuffs. Quite a large part of the oxalic acid of the world comes from the tiny lichens. They are also employed in the making of perfumery because they retain odors for so long a time.

There are between two and three thousand lichens already known in different parts of the world. 


\section{REINDEER MOSS}

THE reindeer is the wealth of the inhabitants of some cold countries. It patiently carries the people from place to place. Its milk and flesh serve for food, its skin for bedclothes, and its tendons for bow strings. These useful animals live entirely upon a small lichen which is found in large quantities on the great plains that border the Arctic Ocean.

- This lichen is called reindeer moss. In the temperate regions it grows in small tufts, and is sometimes found on the sides and tops of mountains, cov-

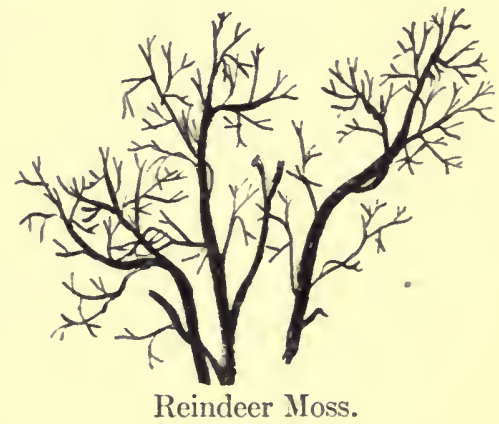
ering places where the snow lies the longest. Its dense tufts are white as new-fallen snow. As you may see, it resembles some forms of coral. It is always erect and much branched. There are tiny holes where the smaller branches join the larger ones. The parts of the plants which grow in large clumps usually mix together and form one mass. This lichen is two inches or more in height. The reindeer find it by scraping with their feet, even when the snow is deep.

In the forests of Lapland the ground is often car- 


\section{LICHENS}

peted with it for many miles. These are fine pastures to the Laplander, and a man who owns a tract of them is thought to be rich, for he can keep great herds of reindeer.

When the snow is frozen so hard that the reindeer cannot get their usual food, they eat another curious lichen called rock hair. This grows upon the trunks and branches of trees. - It hangs down in masses and in long loops or garlands, waving in the wind. When the winter is severe, the Lap-

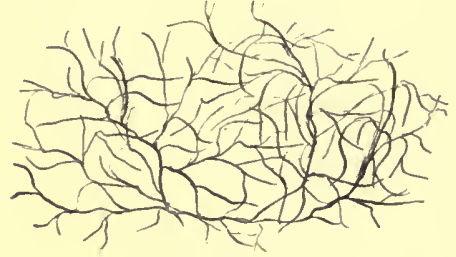

Rock Hair. landers cut down the trees so that the reindeer can feed upon these lichens.

You see from this that these little lichens, which Ruskin calls "humblest of the things that live," provide food, clothing, and means of transportation for a vast number of people in the cold regions. The people live upon the reindeer, and the reindeer upon the lichen.

\section{ICELAND MOSS}

You have just been reading about lichens that furnish food for the reindeer. But in Iceland there is a lichen which forms an important article of food for the people.

This is the Iceland moss. It is found in all the 


\section{ICELAND MOSS}

northern parts of the world. It covers the ground where it grows, and is from one and one-half to four inches high. It grows largest on the lava near the western coast of Iceland. Many people go there during the summer to collect it. It is said that a person can gather four tons of it in a week. It takes three years for new plants to grow where the old ones have been taken away.

The illustration on this page shows you the shape of this lichen. It is tough and leathery, but somewhat soft. It has a very bitter taste. Where it is used for food the people chop it in pieces and leave it in limewater for several days to remove this bitterness. It is then

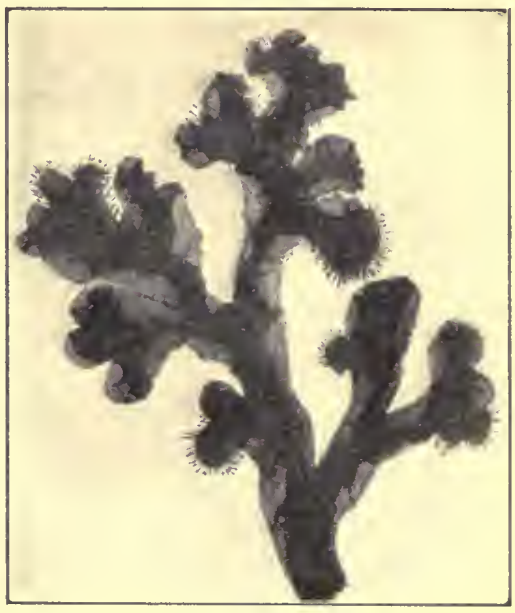

Iceland Moss.

dived, powdered, and mixed with flour of the common knotgrass, and made into cakes. These are eaten with the milk of the reindeer. The poor people say, "A bountiful Providence sends us bread out of the very stones."

Iceland moss is used all over the world. In some countries it is an article of diet for the sick. The doctor 


\section{LICHENS}

often gives it to a patient who is recovering from a severe illness.

The powder looks very much like starch, and, like it, swells in boiling water. When cooled it becomes a fine, jellylike substance which is pleasant to the taste, especially when sweetened and flavored.

\section{LICHENS AS DYESTUFFS}

Dows it not seem strange that some of our most beautiful shades of red, violet, and yellow should be

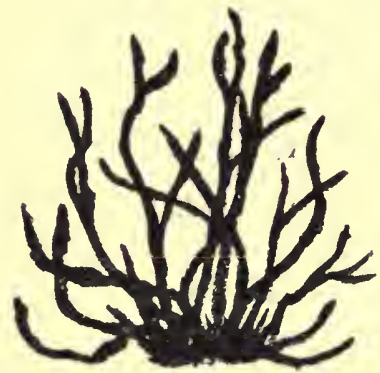

The Orchil (A Bushy Lichen). obtained from the simple little lichens that cover the rocks?

The plants that grow in such places contain the best coloring matter.

The orchil gives a beautiful purple color. A man of Florence, Italy, claims to have discovered in the sixteenth century the art of preparing dye from the orchil. In a short time he made a large fortune. The secret was discovered, and the manufacture was carried to Holland, where quite a trade in this lichen is still carried on. It is believed by some that the use of the orchil was known by the people of ancient Greece.

In temperate climates the orchil is found in small 


\section{LICHENS AS DYESTUFFS}

quantities on rocks by the seaside. In warm countries it grows in great abundance. It looks like a very small shrub without any leaves. The color is a whitish or blue gray, and the entire plant is covered with a mealy powder, or with scattered warty spots. The men who get it ready for the dyer grind it between stones, so as to bruise it but not make it into a powder.

When beaten to a pulp and dried in little cubes about the size of dice, the orchil is called litmus. Paper wet with this is the litmus paper used in chemistry. When put into an acid, like vinegar, this paper becomes red. Place it in an alkali (ammonia, or water with soda in it) and it turns blue again.

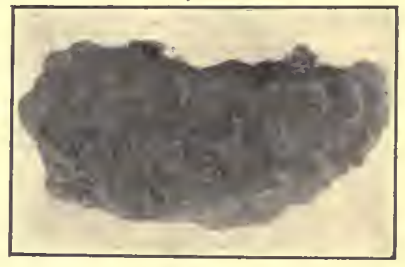

The Cudbear Lichen.

Another useful dye lichen is the rock moss, or cudbear. It is found in Sweden and Sicily. It is of a dirty gray with large, irregular shields of pale flesh color. When the plant is moistened it has a disagreeable odor. The dye made from it gives any tinge of purple or crimson.

The common yellow wall lichen contains yellow and red coloring matter. In some places the children collect it for coloring Easter eggs.

The Scotch tartans of the Highland clans used to be dyed with a common gray lichen found on trees and 


\section{LICHENS}

walls. Many women in the remote parts of that country still dye with this plant.

Without doubt, many other lichens could be used as dyestuffs. The field is open to all, and it is probable that, before many years, some one will gain a knowledge of the uses of these lichens that will be of great benefit.

\section{A FEW COMMON LICHENS}

ONE of the common lichens that we all admire is shown in the picture. It grows on rocks or around the roots of stumps. There is a filmy mass fastened close

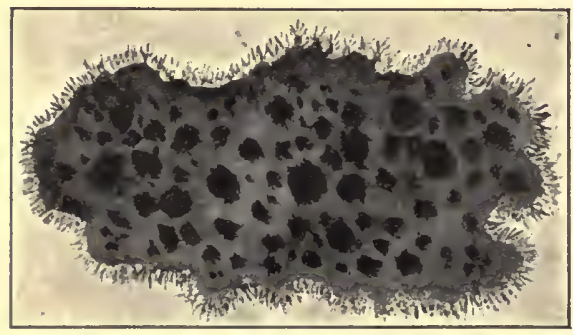

Rock Tripe. to the growing place. From this arise many hollow stalks. The outside of these stalks is often covered with light-green powdery grains. The edges of the little cups may be whole or divided.

Sometimes there are bright-red fruit vessels on their margins. Crabbe, an English poet, calls this the "cup moss with the scarlet tip."

When dry the stalks are quite brittle and easily crumble into dust.

This plant is a member of the same family as the reindeer moss. They are often found growing together. 


\section{A FEW COMMON LICHENS}

Probably this is the "red cup moss" of which Mrs. Hemans speaks in the following lines:

"Oh! green is the turf where my brothers play Through the long, bright hours of the summer day; They find the red cup moss where they climb,

And they chase the bee o'er the scented thyme."

A plant found everywhere in North America is the common dog lichen. When in a moist growing

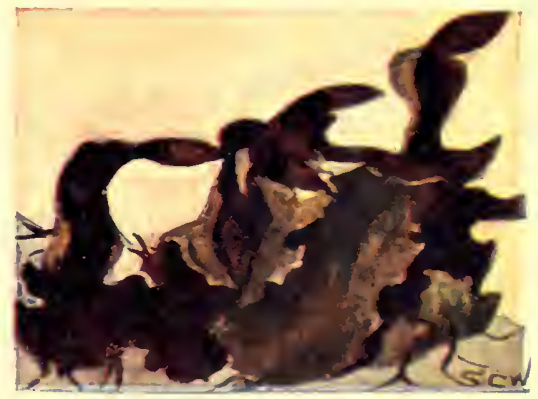

The Dog Lichen. state it is of a brownish-green color; if dried, it becomes a light brown or ashy tint. The leaves are much wrinkled.

Notice the reddish nail-

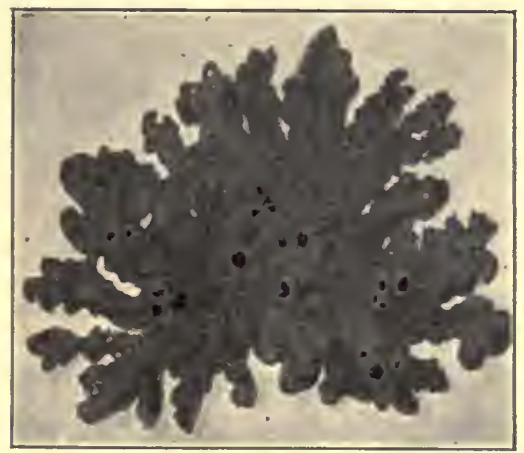

A Lichen of the Parmelia Family. like fruit vessels that grow out from the edges of the leaves; also the small fibers given off from the under side. These catch into the soil and hold the plant in place.

The name "dog lichen " was given it because of its use as a medicine. 


\section{LICHENS}

It was said that a person bitten by a mad dog could be cured by the use of this plant.

A black, leatherlike lichen with black spots scat-

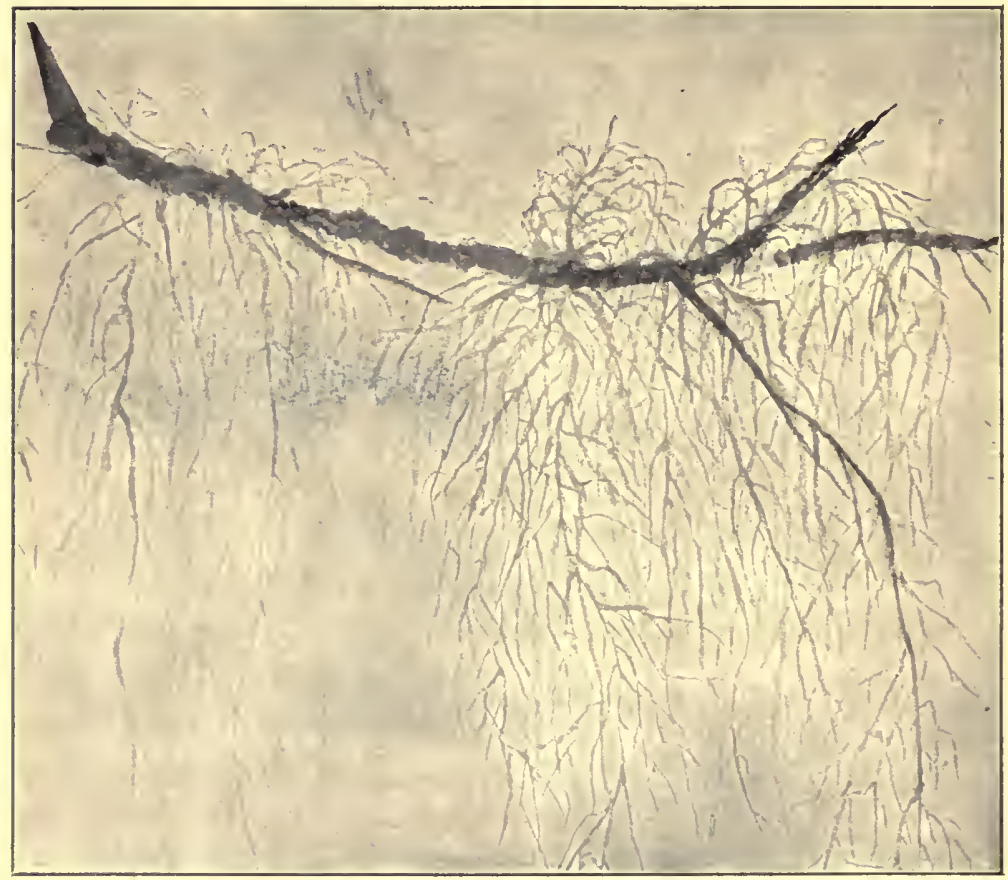

Beard Moss.

"Here are old trees, tall oaks and gnarled pines, That stream with gray-green mosses."

tered over its surface is often found fastened by strong, short fibers to rocks on the mountains. This is the rock tripe. In the arctic region it covers the surface of 


\section{A FEW COMMON LICHENS}

every rock with a dark, gloomy growth. These are bitter lichens, yet they have kept alive hunters and explorers when no other food could be found.

To the Parmelia family belong some of our most common leafy lichens. They are sometimes called leaf lichens or Shield-edge lichens. The common yellow wall moss is one of these that is abundant. It grows almost 'everywhere on rocks, trees, and walls. It is often seen with much fruit on roadside walls and fences.

A lichen sometimes called beard moss, is found in great quantities hanging from trees in the northern part of North America. Longfellow compares trees covered with it to old men "with beards that rest on their bosoms." Another form is found along the coast of California, where the oak trees are often covered with festoons several yards long. These hanging lichens are usually a grayish green or a brownish green in color.

We cannot go into the woods and fields without seeing lichens. Let us keep our eyes open and find as many different kinds as we can. 


\section{SEAWEEDS}

WHo of us does not love the sea?

"On the surface, foam and roar, Restless heave and passionate dash; Shingle rattle along the shore, Gathering boom and thundering crash,

- Under the surface loveliest forms, Feathery fronds with crimson curl, Treasures too deep for the raid of storms, Delicate coral and hidden pearl."

It is not the sea that we are going to talk about, but the "loveliest forms" under the surface that are tossed up to us by the waves.

"The feathery fronds" are not all "with crimson curl." There are the bright-green ones, almost the color of the grass. These are very simple in form, being among the lowest of all plant life. They are made up entirely of soft cells, some in rows and others in layers. New plants are produced by the division of these cells. One plant breaks up and makes two or more plants. 


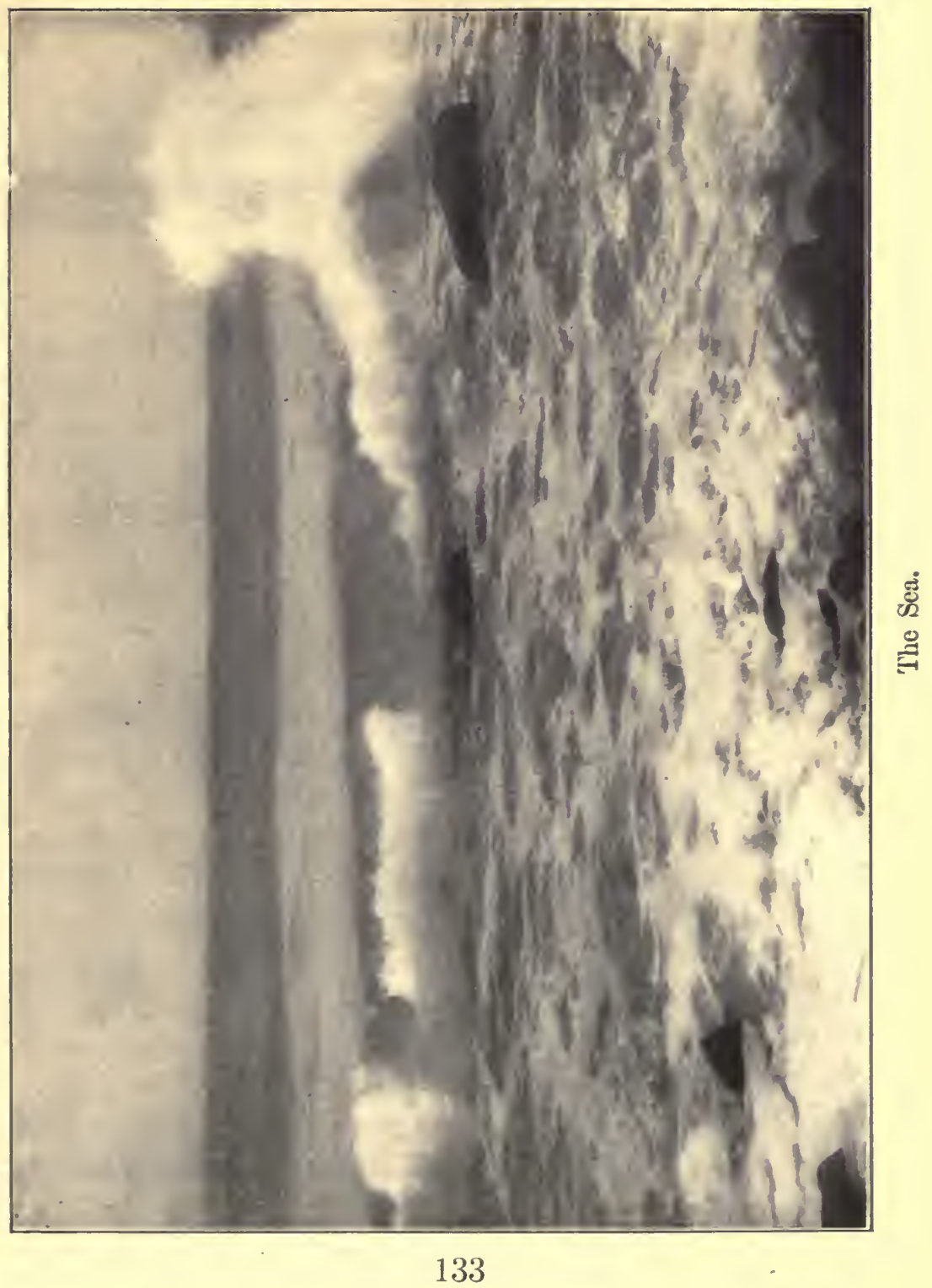


There are also olive or brown seaweeds. Among them are a number which have stem and leaf forms. Many of them have spores from which new plants grow. Some of these seaweeds are quite small; others grow to be several hundred feet in length.

Last and most beautiful are the red seaweeds, in color from a dainty pink to a deep purple. They are not so large nor so leaflike in appearance as the brown ones. They grow in deeper water, but are often washed ashore. Many of them are beautiful featherlike plants. Some, called corallines, are covered with lime.

Among seaweeds the plant is called a frond. A disk or conelike expansion at the base of the frond takes the place of the root found in flowering plants. This is a holdfast by which the frond fastens itself to any material under the water. Seaweeds that grow on sandy shores or on corals have holdfasts that branch like fibrous roots. Holdfasts do not take in nourishment for the plant, as roots do. Seaweeds get their nourishment from the water around them.

Some sea plants. live but a year; others have a long life. Seaweeds vary much in different seasons. If you live near the ocean, try to get some each season and notice the differences. Those which form spores throw them off into the water. Here they sink or are washed to some place where they soon begin to grow. 
Seaweeds give homes and food to millions of living creatures. Iodine, potash, and other medicines are made from them. Various kinds of food are obtained from different species. Farmers along the coast everywhere use them to make the soil better. So you see that seaweeds have uses as well as beauties.

\section{ULVA}

You may often find along the beach a plant which looks like the one in the picture. It is an ulva. Sometimes it is full of holes. Then you may know that it is an old plant, or that a snail found it before you did.

The largest bright-green plants in all seas belong to this family. Its brilliant green is darker when the plant grows in deep water. Two species of this seaweed are found on the Atlantic and Pacific coasts. One is called the widest ulva because it is the largest of any of these plants. The other looks somewhat like a lettuce leaf, and is known as sea lettuce. The frond of the sea lettuce

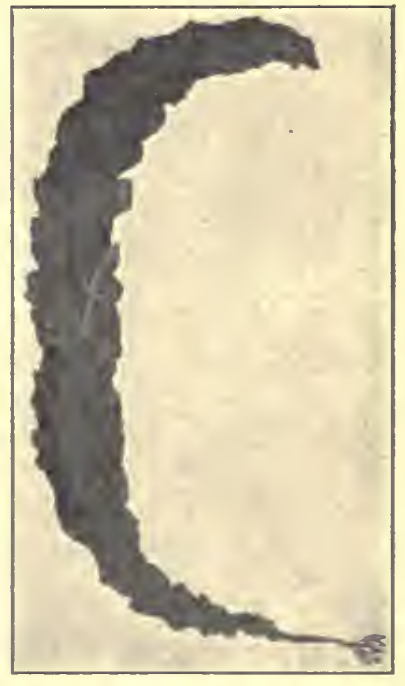

An Ulva. Notice the Holdfast at the Tip. 


\section{SEAWEEDS}

is paler and thinner than that of the widest ulva. When young the sea lettuce is said to form an inflated bag, somewhat like a small toy balloon. Later, this splits along the side and floats out, making a thin leaf of but one layer of cells. This plant is not quite so common as the larger one.

The ulva is one of the seaweeds that lives but a year. It is often found on the beach in the winter, but it is most abundant during the spring and summer months.

\section{FUCUS, OR ROCKWEED}

THE rockweeds are said to make up about one-half of our seaweeds. They are of different kinds. Three are found on our Atlantic coast, and one is common on the Pacific coast.

The plants are large, tough, and leathery. When fresh, they have a distinct olive-green color, but they become almost black when dry. They grow in thick bunches, attached to the rocks by cone-shaped disks or holdfasts. When the tide goes out they hang from the rocks like long fringe. When it rises again, they float and sway in the water like huge bouquets. Sometimes the spore cases are scattered over the entire frond. In other plants they are found at the ends of the branches.

The rockweed that is the most common is called 136 


\section{FUCUS OR ROCKWEED}

the fucus vesiculosus, because of its little-bladders or air vessels. These are oval and are imbedded in the frond each side of the midrib. There are from one to several pairs in each frond.

You can find branches with spores at the seashore in winter or in early spring. If you hold the fronds between your eye and the light you can see the yellow fruit vessels. Cut through the end of a branch and you will find a mass of hard gelatine in which are the spore cases.

Another common rockweed is the knotty fucus. It gets this name

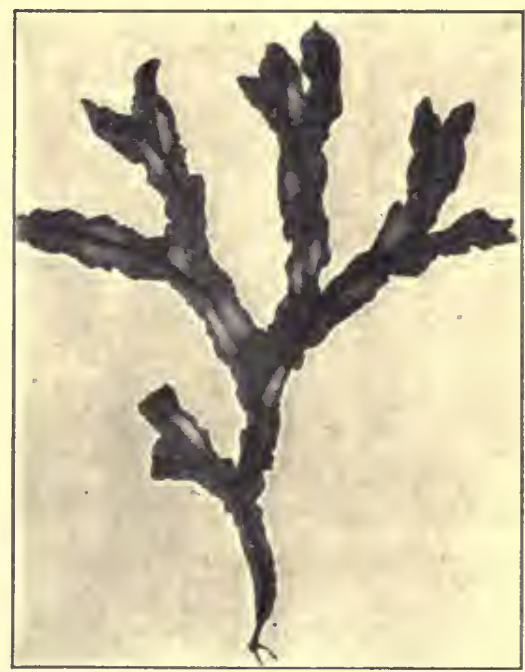

A Rockweed. The Light-Colored Spots are Air Cells.

from the knots or swellings which the air vessels make in the fronds. There is a very narrow frond of the same width throughout. Its branches do not fork as in the other kinds, but it puts out branches of different lengths from the sides of the main stem. With these are short branchlets whose wider ends thicken and bear the spore cases.

The third rockweed found on the Atlantic coast 


\section{SEAWEEDS}

is known as the forked fucus. This is wider and shorter than the others. It has no air bladders. This plant is found in deeper waters than are the other forms of fucus. It is a seaweed seldom seen on the coast south of Boston.

On the western coast of North America there is another common form of rockweed. It has a cylindrical frond about as big around as a small wire nail. It forks near the base. Then each part forks farther and farther apart. There are generally six or seven forkings. The plant grows to the height of three or four inches. There are no air vessels.

If you were to visit some places along the coast you would see women and children gathering the fucus. They would tell you that they were getting "kelp" for the garden. You might also see in some of the near-by yards how they used the "kelp."

In Scotland and Norway where it is found the fucus vesiculosus is eagerly eaten in winter by the cattle.

\section{SARGASSUM, OR GULFWEED}

"THE gulfweed belongs to the fucus family. It is so different from the rockweed that it seems best to place it in a chapter by itself. It is also called sargassum, which is the Spanish for sea lentils.

As you may see in the picture, it has a stem and 138 


\section{SARGASSUM, OR GULFWEED}

leaves, and looks very much like some of the higher forms of plants. The stem is round and grows from one to three feet in length. The branches are alternate. The leaves are long and narrow with a midrib and toothed edges. 'They grow out from the stem on short stalks. All over their surface may be seen tiny dark spots. You cannot see these in the picture, but they may be found on a large plant. On this smaller one they are quite distinct when seen with a magnifying glass.

Notice the little round balls all over the plant. They look like little berries on stems. These are the air vessels. Do you remember where we found them in the rockweeds?

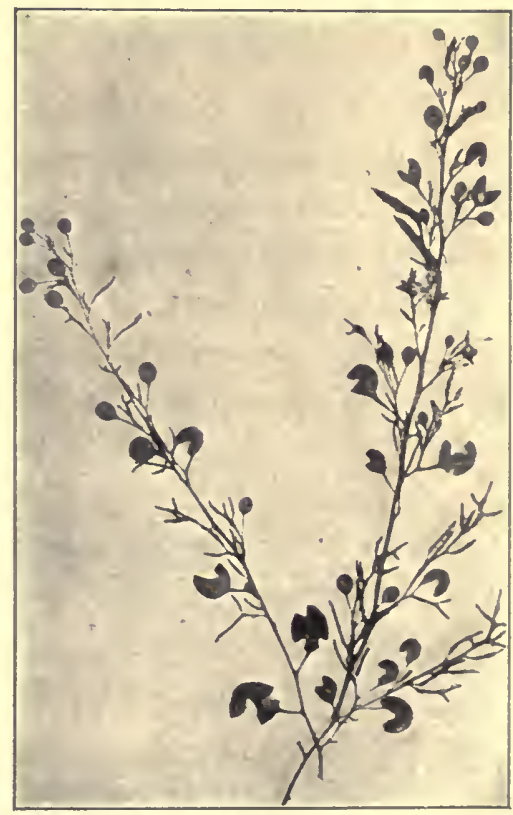

Sargassum, or Gulfweed.

There are many twiglike forms that come out where the leaf stems do. These are the fruit vessels. Within them are the spore cases with their dustlike spores.

The plant which is shown in the picture was found at Cape Cod. It grows upon small stones and pebbles 
along the coast, just below low-tide marks. In Long Island sound it is quite common.

There is another form of sargassum which you will like to know about. Great banks or floating meadows of it are out in the midst of the Atlantic ocean. These are called the sargasso sea, on account of the floating plants which form it.

This place was first reported by Columbus. His sailors were frightened at the strange appearance and wanted to turn back. They thought the vessel would strike against the rocks. After sailing for fifteen days they came into clear water. Since that time the Sargasso sea has interested all sailors. Such an extent of plants of one kind is not known elsewhere.

Many animals live among this mass of seaweed. Numerous air vessels make the plants light enough to bear their weight.

Often the gulfweed surrounds a ship and hinders its progress, and then again, hours may pass without a sight of the plant.

This seaweed is found attached to the rocks on the coast of Florida and in the West Indies. Plants are sometimes carried by the current northward and are found washed ashore. Perhaps this is the seaweed that our poet Longfellow had in mind when he wrote the following lines: 


\section{EDIBLE SEAWEEDS}

"When descends on the Atlantic

The gigantic

Storm wind of the equinox,

Landward in his wrath he scourges

The toiling surges,

Laden with seaweed from the rocks.

From Bermuda's reefs, from edges

Of sunken ledges

In some far-off, bright Azore;

From Bahama and the dashing,

Silver-flashing

Surges of San Salvador.

Ever drifting, drifting, drifting

On the shifting

Currents of the restless main;

Till in sheltered coves, and reaches

Of sandy beaches,

All have found repose again."

\section{EDIBLE SEAWEEDS}

THERE are a number of seaweeds that are used for food. One of these is the carrageen or Irish moss. Its extensive use by the peasants of the coast of Ireland gave it this name. It is collected along the eastern 


\section{SEAWEEDS}

coast of the United States. After being dried and bleached in the sun, it is taken to the grocer. He sells it to his customers to make into blanc mange and puddings.

The frond begins with a flattened stem. When about an inch high, this stem divides and subdivides

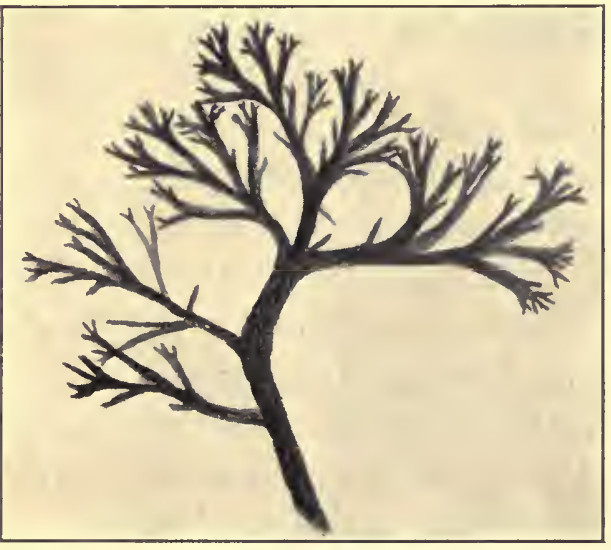

Carrageen, or Irish Moss. a great many times.

The frond is generally the shape of a fan. It is thick, tough, and leathery, and grows from two inches to ten inches in length.

The size and color of the plant depend much upon where it grows. In shallow tide-pools it is small and pale; under the shelter of rocks in deep water it grows in dense masses, and is a dark purplish-red or a reddish green. The very dark shades have changing rainbow colors when seen through the water with the sun shining upon it. They turn quite dark when dry. Another seaweed that is used for food is known as dulse. In Norway and Sweden this is eaten by the sheep and goats. Among the peasants of the British 


\section{EDIBLE SEAWEEDS}

Isles it is a common article of food. In the United States, it is found on the New England and the California coasts.

The color of the dulse is a purplish red. It gen-

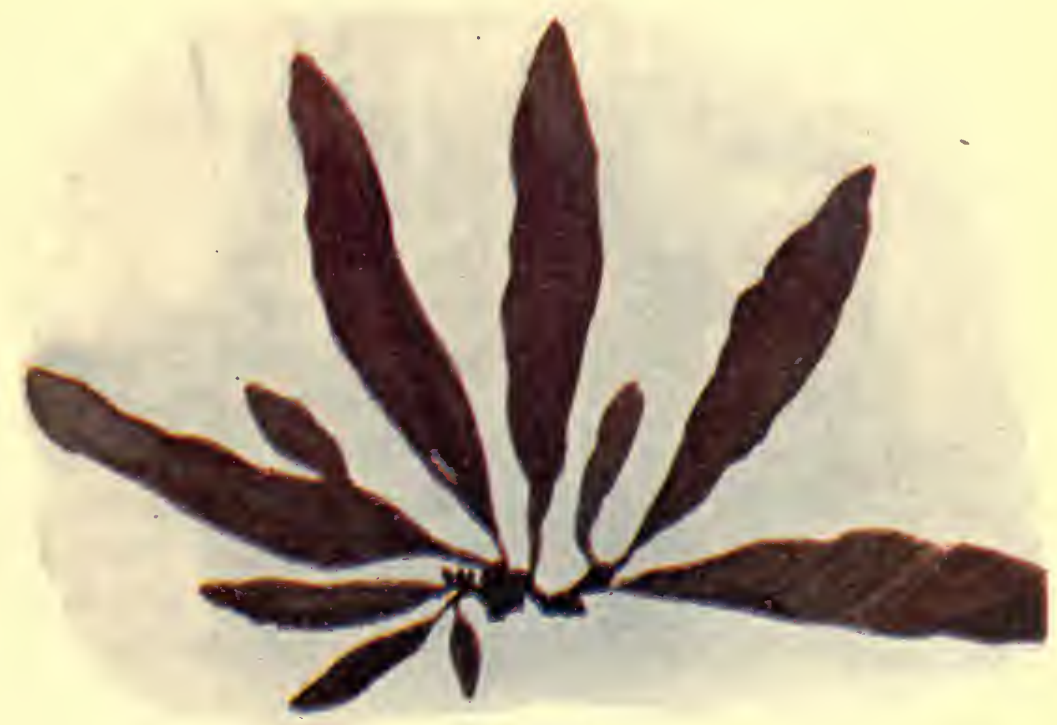

The Dulse:

erally grows upon the rocks, but it is sometimes found upon the fucus and other seaweeds.

A third edible seaweed is the laver. This is common everywhere. It is known by its dark-purplish frond. This is thin and somewhat elastic. It shines like satin, especially when in the water. 


\section{SEAWEEDS}

The laver is much used in Great Britain as an article of food for a relish with roast meat. The Chinese

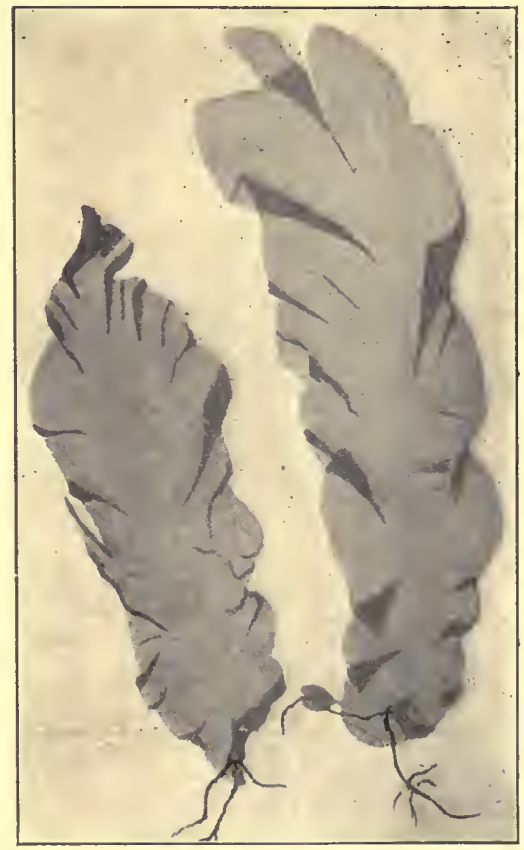

Porphyra, or Laver. use it for making soup. It is an annual-that is, it lives but one year.

\section{GIANT SEAWEEDS}

THE largest of all known plants is a seaweed. This seems strange when we think of all the great plants and trees that are found growing on the land. It is a queer-looking plant, too. Let us see how it grows. There is a thin naked stem from 700 to 1,500 feet long. It is only about one-fourth of an inch thick. At the end of this stem is a fern-like leaf that is about fifty feet in length. Where it joins the stem each leaflet expands into an air vessel as large as an egg. These air vessels hold up the great frond which floats on the top of the water. This plant is found on the Pacific coast of North America. 


\section{SEA TANGLE}

There is another order of brown seaweed which grows to be very large. Belonging to this order are the oarweeds, tangle, and sea colander.

The oarweeds have stout, woody stems, and broad, tough, glossy leaves of a dark olive green. The large fronds float like streamers in the water, while the fishes swim in and out among them.

The sea colander has a round stem which becomes flattened in the leaf, and extends through it like a midrib. The frond has wavy edges. Its whole surface is covered with holes, which give the plant its name.

In the sea tangle the leaf is narrow and ribbonlike. Its length is from three to thirty feet. It grows at the end of a solid stem that is from three inches to four feet long. The edge of the frond is much waved. Through the center there is a band of sunken spots. This seaweed is found on the northern shore of both the Atlantic and the Pacific oceans. Perhaps you will like to read a poem about the little maid and her sea tangle.

\section{SEA TANGLE}

"Go show to earth your power!' the East Wind cried Commanding; and the swift submissive seas, In ordered files, like liquid mountains, glide, Moving from sky to sky with godlike ease. 
Below a cliff, where mused a little maid, It struck. Its voice in thunder cried, 'Beware.' But, to delight her, instantly displayed A fount of showering diamonds in the air.

.... The wave passed on;

Touching each shore.with silver-sandled feet, But tossed, in flying, in the sun which shone, A handful, to her lap, of sea blooms sweet.

More delicate than forms that frost doth weave On window panes are Ocean's filmy brood; Remembering the awful home they leave, Their hues to that dim underworld subdued.

Fair spread on pages white, I saw arrayed These fairy children of a sire so stern; Their beauty charmed me; while the little maid Spoke of her new-found love with cheeks which burn.

'So grand, so terrible, how could I know He cared for these?' she faltered, 'darlings dear! That his great heart could nurture them and glow With such a love beneath such looks severe?'

Like God, the Ocean, too, the least can heed, Yearn in a moon-led quest to farthest shores, And fondle in delight its smallest weed, Yet look to Him it mirrors and adores." 


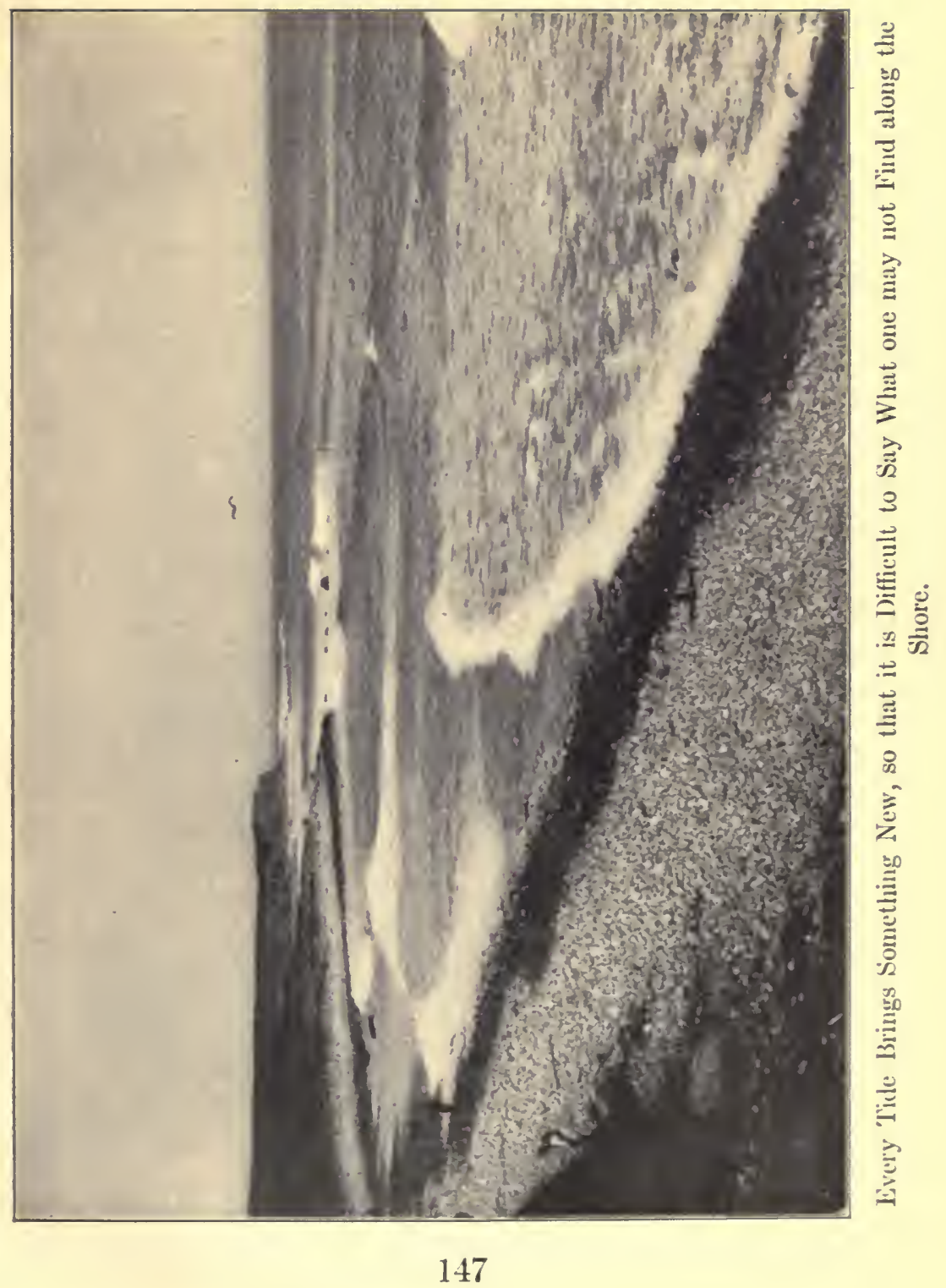




\section{SEAWEEDS}

\section{SEA FLOWERS}

WhAT a contrast to the giant seaweeds are some of the delicate little plants found along our coasts. The soft, silky tufts of the cal-li-tham'-ni-on are of cobweb fineness. Their brilliant red color with the darker dots. along the branches make them look like flowers.

"O call us not weeds, but flowers of the sea, For lovely and bright and gay tinted are we; Our blush is as deep as the rose of the bowers, Then call us not weeds; we are Ocean's gay flowers."

The feather weed is another delicate red sea plant. This grows under the rockweed or fucus on the sides

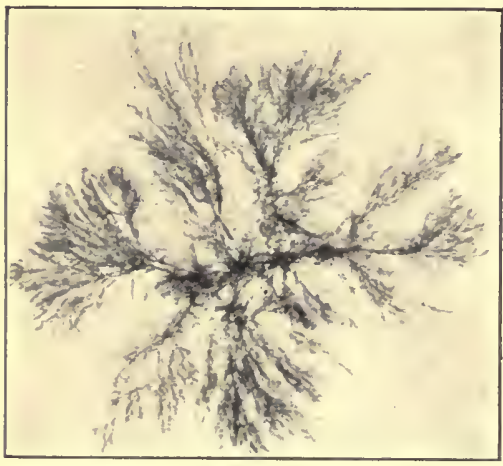

Callathamium. (A Beautiful Red with Darker Dots along the Branches.) of the cliff near low-water mark. It is often found in summer and fall among masses of seaweed left by the waves. The fruit vessels grow at the tips of the feathery branchlets.

The grasslike seaweed which you see on this page is of a bright-green color. It is common everywhere. The fronds are fine, hair-like tubes, 


\section{SEA FLOWERS}

soft and densely tufted. The name is a long one and may be hard to remember. It is an en-ter-o-mor'-pha. This plant of ten grows on the bottoms of ships. The sailors call it grass.

Coarser than any of these is the pitcher weed or cer-a'-mi-um, a sea plant that may be easily known. The tops of the branches bend toward each other. At the last fork they are so curved in and hooked that they look like two tiny fishhooks turned point to point. If you look at these plants

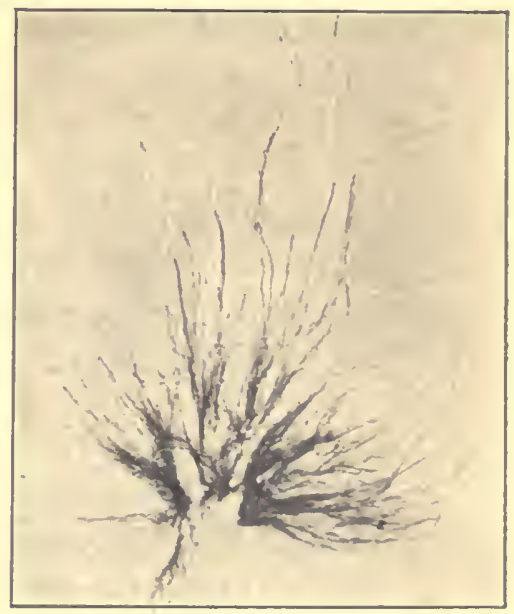

Enteromorpha (bright-green). through a magnifying glass you find that the stems and branches are striped in dark and light colors. Some of the small forms of the pitcher weed are often found

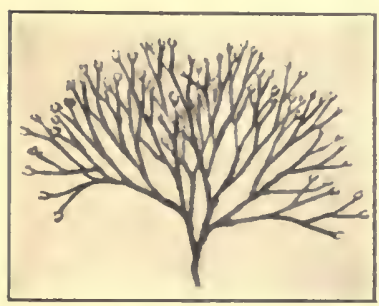

Pitcher Weed or Ceramium. growing on the Irish moss plants.

Another pretty "flower of the sea" is the chenille weed. Out of the water it looks like a stringy mass of pink or purple jelly. Floating in the sea there is a delicate pink piece of chenille. 


\section{SEAWEEDS}

Much of this plant is found between Fort Hamilton and Coney Island. It extends northward to Cape Cod, but no farther.

These are only a few of the many seaweeds that are found among the rocks or along the sand.

"Search the shore,

Each rock pool has its treasure, every tide Strews on the yellow sand from Ocean's lap Weed than our flowers more fair, and fitted more To beautify the album's tasteful page."

Beautiful ferns with fronds so green; In woods and meadows are often seen; Beautiful mushrooms in colors bright, Hiding their spores from the strong sunlight. Beautiful mosses with tiny leaves Cover the rocks and the fallen trees. Beautiful lichens in gray and brown Remain with us when the snow falls down. Beautiful seaweeds out of the sea Are cast on the sand for you and me. Beautiful plants are these, large and small; God has made them for us all. 


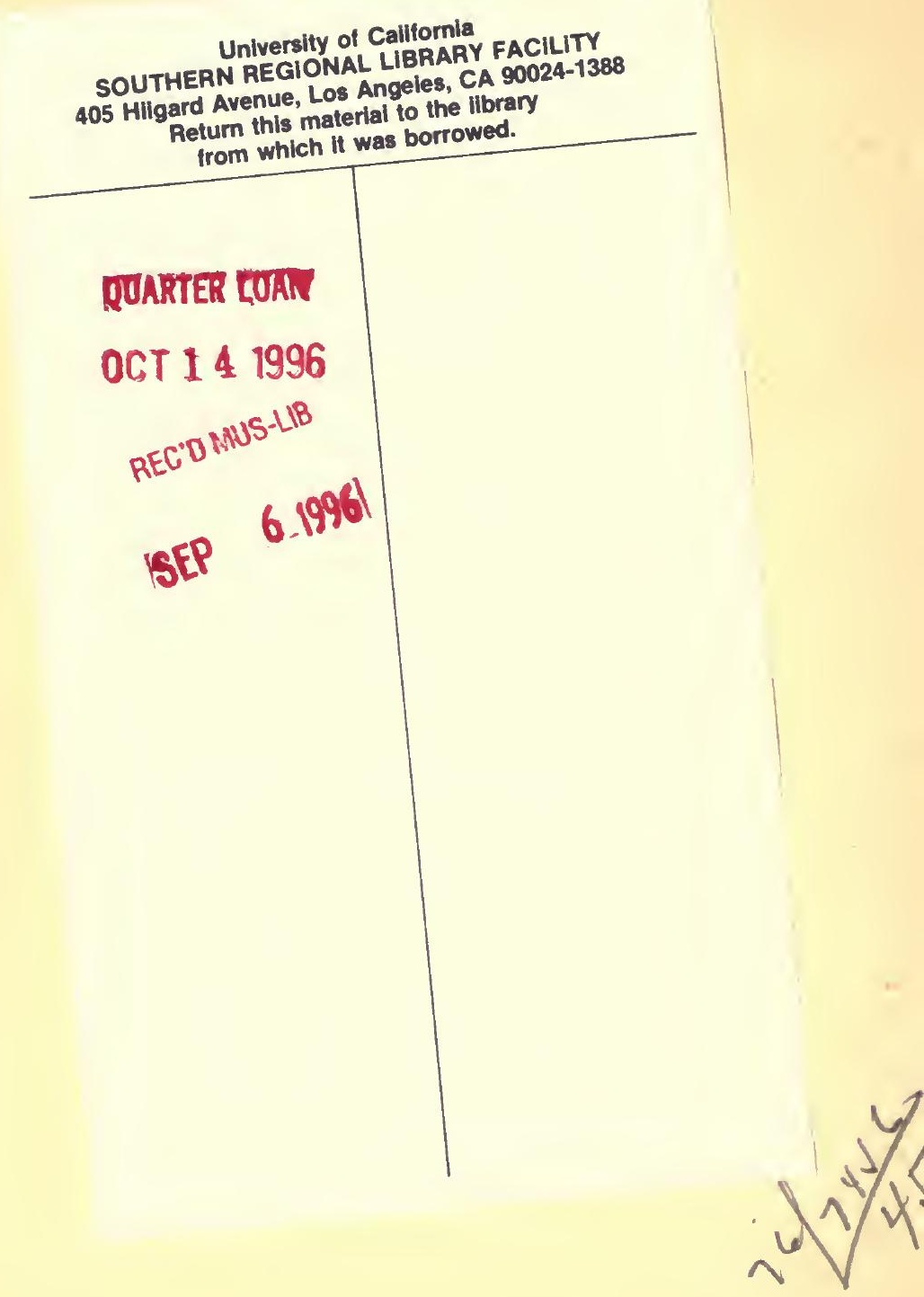


UC SOUTHERN REGIONAL LUBAAY FACULTY

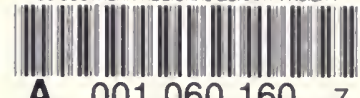

A $001060160 \quad 7$ 
(1)

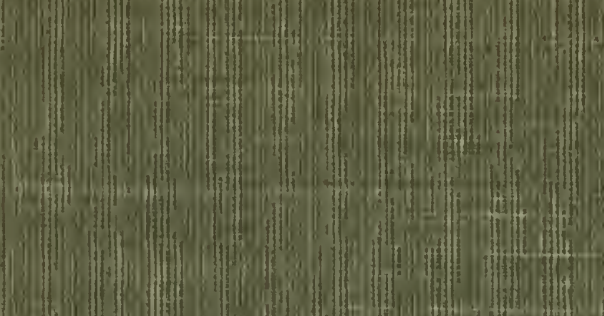

(1)

\{fong

(2)

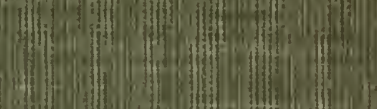

(1)

(1).

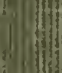

(1)

(10)

(3)

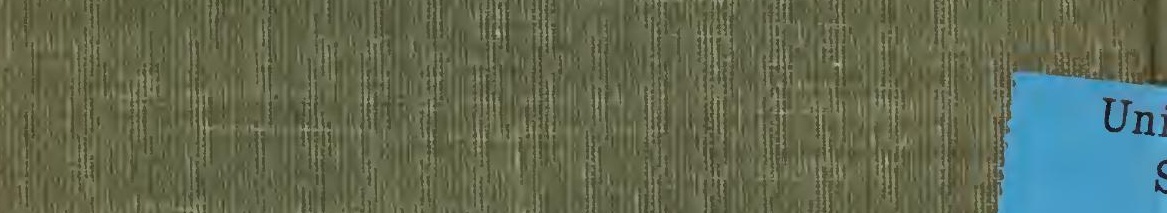

(t)

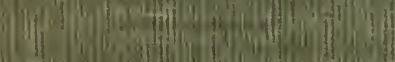

if

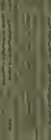

(1) (I)

1.

19. If

(1) 13

Mat.

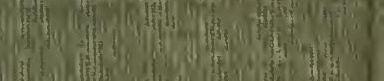

12 -1 1.4.

(1) 